$$
\begin{gathered}
\text { UNIVERSIDADE DE SÃO PAULO } \\
\text { FACULDADE DE MEDICINA DE RIBEIRÃO PRETO }
\end{gathered}
$$

Estudo das Regiões Controladoras de Imprinting 1 e 2 em oócitos, embriões e placentas de primeiro trimestre

Cristiana Libardi Miranda Furtado

Ribeirão Preto 
Cristiana Libardi Miranda Furtado

\section{Estudo das Regiões Controladoras de Imprinting 1 e 2 em oócitos, embriões e placentas de primeiro trimestre}

Tese apresentada à Faculdade de Medicina de Ribeirão Preto da Universidade de São Paulo para obtenção do título de Doutor em Ciências. Área de Concentração: Genética

Orientadora: Profa. Dra. Ester Silveira Ramos 
AUTORIZO A DIVULGAÇÃO TOTAL OU PARCIAL DESTE TRABALHO, POR QUALQUER MEIO CONVENCIONAL OU ELETRÔNICO, PARA FINS DE ESTUDO E PESQUISA, DESDE QUE CITADA A FONTE.

\section{FICHA CATALOGRÁFICA}

Miranda-Furtado, Cristiana Libardi

Estudo das Regiões Controladoras de Imprinting 1 e 2 em oócitos, embriões e placentas de primeiro trimestre, 2012.

103p. il.; $30 \mathrm{~cm}$

Tese de Doutorado, apresentada à Faculdade de Medicina de Ribeirão Preto/USP - Área de concentração: Genética.

Orientadora: Ramos, Ester Silveira

1. Imprinting genômico; 2. Metilação; 3. Expressão Gênica; 4. Fertilização in vitro; 6. Placenta de primeiro trimestre; 7. Embrião; 8. Oócito 
Cristiana Libardi Miranda Furtado

ESTUDO DAS REGIÕES CONTROLADORAS DE IMPRINTING 1 E 2 EM OÓCITOS, EMBRIÕES E PLACENTAS DE PRIMEIRO TRIMESTRE, 2012.

Tese apresentada à Faculdade de Medicina de Ribeirão Preto da Universidade de São Paulo para obtenção do título de Doutor em Ciências. Área de Concentração: Genética

\section{BANCA EXAMINADORA}

Data da Defesa:

Profa Dra Ester Silveira Ramos

Julgamento:

Assinatura:

Prof. Dr.

Julgamento:

Assinatura:

Prof. Dr.

Julgamento:

Assinatura:

Prof. Dr.

Julgamento:

Assinatura:

Prof. Dr.

Julgamento:

Assinatura: 
"Eu te louvarei, porque de um modo terrível e tão maravilhoso fui formado; maravilhosa são as tuas obras, e a minha alma o sabe muito bem." (Salmos 139:14) 
Ao meu Senhor e meu Deus, Ao meu amado marido;

A minha querida mãe, 


\section{AGRADECIMENTOS}

Nenhuma conquista é adquirida sozinha, muitos são os que choram conosco, os que dão risadas ao nosso lado, os que nos aconselham, os que estão longe fisicamente, mas perto no coração, a todos que de alguma forma contribuíram para este momento, o meu

\section{Muito Obrigada!}

Primeiramente e a cima de tudo, ao meu Senhor e meu Deus, por tudo o que tenho, tudo o que sou e tudo o que vier a ser; por ser meu melhor amigo e porque: "Tu me cercaste em volta e puseste sobre mim a tua mão. Tal ciência é para mim maravilhosíssima; tão alta, que não a posso atingir" (Salmos 139:5-6).

À minha orientadora, Profa. Dra. Ester Silveira Ramos, pela oportunidade, orientação e confiança a mim depositada;

À minha supervisora internacional, Profa. Dra. Susana Chuva de Sousa Lopes, pela oportunidade, confiança e por todas as valiosas discussões científicas;

Ao Prof. Dr. Bernard A J Roelen por toda ajuda na realização deste trabalho e por toda disposição;

Ao Prof. Dr. Flávio Vieira Meirelles, pelas amostras de placenta e embrião bovinos concedidas;

Ao meu amado marido, Gilvan, pela ajuda científica na elaboração dessa tese e principalmente por ser meu porto seguro, a minha força, a minha alegria, pelo seu amor e dedicação, porque ao seu lado tudo se torna mais fácil. Obrigada meu amor, ao seu lado a minha felicidade é plena. Te amo!

À minha mãe, Ana, por todo amor, por ser um exemplo de mãe e "pai", um exemplo de força, pelo seu grande amor, por fazer o impossível para ver um sorriso no meu rosto e por sempre estar perto mesmo estando longe. Te amo, mãe!

Ao meu pai Wilson por todo amor, carinho e dedicação. Te amo, pai!!

À minha sogra Ana Lúcia e ao meu sogro Gilberto, por sempre estarem ao nosso lado, por todo amor, carinho e orações, que não foram poucas. Amo vocês!

À minha família, em especial ao meu cunhado Gilnei, às minhas avós Carmelitas e Aparecida, a minha tia Elenir e aos meus primos Josi e Wallace, e a minha concunhada a Nayra, por todo amor, carinho e orações a mim dedicadas;

À minha amiga irmã Gisele, por toda ajuda durante esses anos, pela amizade que a cada dia é fortalecida e por sempre estar ao meu lado mesmo nos momentos mais difíceis; 
Aos meus amados amigos e irmãos em Cristo, Claudia, Raquel Fonseca, Monica (Holanda), Bruna, Rachel, Victor, Liliane e Lucas, pela amizade, carinho e pelas valiosas orações;

Ao meu amado Pr. Adriano, por toda paciência e pelas valiosas orações;

Aos amigos e irmãos da Igreja Cristã Maranata, por todo carinho e pelas valiosas orações.

Ao irmão em Cristo e Prof. Dr. Tiago Campos Pereira, pela amizade, pelas conversas científicas e por todas as orações;

À minha querida amiga Flávia Gaona, por toda ajuda até aqui, pela amizade e companheirismo, e porque trabalhar ao seu lado foi muito valioso para mim;

Ao meu companheiro de Holanda, Filipe Brum Machado, pela amizade e carinho, e pelos momentos que trabalhamos juntos no LUMC, e por toda ajuda científica e pessoal;

À amiga Sarah Blima, pela ajuda na formatação dessa tese, pela amizade, pela força e por todo carinho;

Aos amigos do bloco C, Adriana Renzi, Murilo, Hélida, Karina, Larissa, Vivian, Rafaela, Ciro e Anderson por todos os momentos que passamos juntos, pelo incentivo e pela amizade, sem vocês com certeza teria sido muito mais difícil;

Às amigas, Lisandra, Paulinha, Francielle, Fernanda, Andréia, Karine e Adriane pelos bons momentos que passamos, pela amizade, pelo companheirismo e incentivo sempre presentes;

Ao Prof. Dr. Álvaro Fabrício Lopes Rios, pelas ajudas práticas e teóricas e pela amizade.

Aos colegas do LUMC, Maria Fernandes, Ana Bernardo, David van Bruggen e Liesbeth van lepren, por todo apoio, dedicação e por fazer a minha estadia na Holanda mais fácil.

Aos técnicos do bloco C, Reginaldo, Marli e Silvio, pela amizade, carinho e toda ajuda no laboratório;

Aos demais funcionários do bloco $\mathrm{C}$, em especial à amiga Mara por toda alegria $\mathrm{e}$ amizade e por fazer nossos almoços mais divertidos;

À Profa. Dra. Lúcia Regina Marteli, pela agradável convivência.

Ao Prof. Dr. Raysildo Barbosa Lôbo, por toda a contribuição laboratorial.

Ao Prof. Dr. Espencer Egea Soares, pela amizade e atenção

Ao Prof. Dr. Aldrin Vieira Pires, meu ex-orientador, pela amizade e pela confiança em mim depositada ainda na iniciação científica e pela primeira porta que me foi aberta para eu chegar até aqui.

Às secretárias do departamento de genética, em especial a Susie, por toda dedicação.

Às instituições: CNPq, CAPES, FAPESP, FAEPA e ao LUMC, pelo apoio financeiro. 
Este trabalho foi desenvolvido com o apoio financeiro da Coordenação de Aperfeiçoamento de Pessoal de Nível Superior (CAPES), da Fundação de Amparo ao Ensino Pesquisa e assistência do Hospital das Clínicas da Faculdade de Medicina de Ribeirão Preto (FAEPA), do Conselho Nacional de Desenvolvimento de Pesquisa (CNPq) e da Fundação de Apoio à Pesquisa do Estado de São Paulo (FAPESP) 
RESUMO 
MIRANDA-FURTADO, CL. Estudo das Regiões Controladoras de Imprinting 1 e 2 em oócitos, embriões e placentas de primeiro trimestre, 2012. 103p. Tese (Doutorado) Faculdade de Medicina de Ribeirão Preto, Universidade de São Paulo.

O imprinting genômico é um processo epigenético essencial para o desenvolvimento normal de mamíferos com placenta e refere-se à expressão gênica alelo-específica, de acordo com a origem parental. A expressão dos genes marcados por imprinting é controlada por regiões diferencialmente metiladas (DMRs), situadas em regiões controladoras de imprinting (ICRs). O cromossomo 29 de Bos taurus possui dois domínios cromossômicos semelhantes à região 11p15.5 de humanos, que são denominados KvDMR1 (na ICR2) e H19DMR (na ICR1). Essas ICRs controlam um cluster de genes importantes para o crescimento e desenvolvimento, sendo a KvDMR1 metilada no alelo materno e a e H19DMR metilada no alelo paterno. No presente trabalho, foi verificado o padrão de metilação da KvDMR1 e da H19DMR em oócitos não maturados $(\mathrm{Vg})$ e maturados in vitro (MII) e nos blastocistos inicial (Bi) e expandido (Bx) bovinos e em placentas bovinas e humanas de primeiro trimestre. Foram coletados oócitos e embriões pré-implantação no estágio de blastocisto produzidos pela técnica de Fertilização in vitro. Também foram coletados o tecido placentário e de um feto bovino de 49 dias e de uma placenta humana, com idade gestacional de 12 semanas. $O$ DNA genômico foi extraído e modificado com bissulfito de sódio. O padrão de metilação das regiões KvDMR1 e H19DMR foi verificado por meio de clonagem e seqüenciamento do DNA modificado com bissulfito de sódio. Para as análises de expressão gênica nos oócitos e blastocistos, foi realizada a extração do RNA e em seguida o cDNA foi produzido para a quantificação relativa da expressão gênica por meio da técnica de PCR em tempo real. Os resultados de metilação para a amostra controle de espermatozóide apresentaram um perfil hipometilado para a KvDMR1 e hipermetilado para a H19DMR. Os oócitos Vg e MII mostraram um perfil hipermetilado para a KvDMR1 e nos Bi e Bx foi observado um perfil hipermetilado e hipometilado, respectivamente. Para a H19DMR, foi observado um perfil hipermetilado para as amostras $\mathrm{Vg}$ e $\mathrm{MII}$, sendo que para os $\mathrm{Bi}$ foi observado um perfil hipometilado e, para os Bx, um perfil monoalélico de expressão. A expressão dos genes LIT1 e IGF2 foi relativamente baixa nas amostras analisadas, sendo que o gene LIT1 foi expresso nos mesmos níveis para todas as amostras e o IGF2 não foi expresso nos $\mathrm{Bi}$ e Bx. Os oócitos MII apresentaram altos níveis de expressão do IGF2 quando comparados com os oócitos $\mathrm{Vg}$. Nas placentas precoces de bovinos, a porcentagem de metilação para a KvDMR1 variou entre os cotilédones de $39,6 \%$. e $88,9 \%$. A porcentagem de metilação para a H19DMR nos cotilédones variou entre $35,0 \%$ e $57,0 \%$, sendo que apenas uma amostra apresentava-se completamente demetilada para esta ICR. Nas análises das vilosidades humanas, foi observado um perfil hipermetilado em todas as amostras analisadas, em que as porcentagens de metilação para a KvDMR1 e H19DMR variaram entre 84,4\% e 97,9\%. Os resultados mostram um perfil alterado de metilação nos oóctios MII para as duas regiões analisadas, e uma alteração nas amostras de oócitos Vg para a H19DMR. Para os blastocistos, o esperado seria um perfil monoalélico para as duas regiões, no entanto, esse resultado só foi encontrado para os Bx na H19DMR. Em bovinos, as DMRs apresentaram um funcionamento antagônico, enquanto a KvDMR1 tende a uma hipermetilação a H19DMR tende a uma hipometilação. O resultado das análises comparativas das placentas bovina e humana não sugerem uma relação do padrão de metilação dessas regiões entre essas duas espécies, no entanto, servem de base para o conhecimento do imprinting na placenta. Os estudos nos oócitos e blastocistos realizados representam um passo inicial na investigação da influencia das tecnologias de reprodução assistida no desenvolvimento embrionário, sendo o primeiro relato do funcionamento dessas DMRs nas amostras de oócitos e embriões pré-implantação bovinos.

Palavras-chave: Imprinting genômico; Metilação; Expressão Gênica; Fertilização in vitro; Placenta de primeiro trimestre; Embrião; Oócito. 
ABSTRACT 
MIRANDA-FURTADO, CL. Imprinting Control Regions 1 and 2 in oocytes, embryos and early placenta. 2012. 103p. Ph.D. Thesis - Faculdade de Medicina de Ribeirão Preto, Universidade de São Paulo.

Genomic imprinting is an epigenetic process that plays an essential role in the development of placental mammals with a parent-of-origin-specific manner of gene expression, in which only one allele is expressed. The imprinted gene expression is controlled by differentially methylated regions (DMRs), located in imprinting control regions (ICRs). In Bos Taurus, chromosome 29 presents two imprinted domains similar to human $11 \mathrm{p} 15.5$ region which are named KDMR1 (in the ICR2) and H19DMR (in the ICR1). Several genes that play an essential role in growth and development are under the control of the ICRs, in which the KvDMR1 is methylated on the maternal allele and the H19DMR is methylated on the paternal allele. In this study, the DNA methylation status of the KvDMR1 and H19DMR was verified in bovine non-matured germinative vesicle (GV) in vitro matured (MII) oocytes, as well in early (EA) and expanded (EX) blastocysts, and in bovine and human early placenta. The oocytes and blastocysts were collected after in vitro fertilization (IVF) techniques. Tissues from bovine placenta and fetus with 49 days of gestational age and human placenta with 12 weeks of gestational age were also collected. The DNA was extracted and modified by sodium bisulfite. The methylation pattern of KvDMR1 e H19DMR was verified by cloning and bisulfite sequencing. RNA extraction and cDNA synthesis for the relative quantification of gene expression by real time PCR were performed for oocytes and blastocysts. The methylation profile for the control sample of sperm was hypomethylated for KvDMR1 and hypermethylated for H19DMR. The GV and MII oocytes showed a hypermethylated pattern for KvDMR1 and in the EA and EX was hypermethylated and hypomethylated, respectively. The H19DMR displayed a hypermethylated pattern for GV and MII oocytes. For EA was observed a hypomethylated profile and EX presented a monoallelic expression. The LIT1 and IGF2 gene expression were low for all samples, however the LIT1 had the same level of expression in all samples while the IGF2 was not expressed in EA and EX. The MII oocytes showed high levels of IGF2 gene expression when compared with GV oocytes. The methylation levels for KvDMR1 in bovine early placenta varied between the cotyledons $(39,6 \%$ and $88,9 \%)$. The percentage of methylation for H19DMR in cotyledons varied between $57.0 \%$ to $35.0 \%$. Only one sample was not methylated for this ICR 1 . In human villous, a hypermethylated profile was observed for all samples, and the percentage of methylation for KvDMR1 and H19DMR varied between $84.4 \%$ e $97.9 \%$. The results show an altered methylation profile in MII oocytes for two analysed regions and an alteration of H19DMR in GV oocytes. The expected for blastocysts was a monoallelic profile for KvDMR1 and H19DMR, however these results were observed only in EX for H19DMR. In bovine, the methylation levels of KvDMR1 and H19DMR seems to work antagonistically. While the KvDMR1 tended to hypermethylation, the ICR1 tended to a hypomethylation. The comparative analysis of bovine and human early placentas does not suggest a relationship between the methylation patterns of these regions in these two species. However, these studies provide the basis for the understanding of imprinting in the placenta. The study in oocytes and blastocysts represent an initial investigation in understanding how the assisted reproductive technologies affect the embryo growth and development, and this is the first report on the methylation patterns of KvDMR1 and H19DMR in bovine oocytes and blastocysts.

Key-words: Genomic Imprinting; Methylation; Gene expression; In vitro fertilization; Early placenta; Embryo; Oocyte. 


\section{LISTA DE ABREVIATURAS E SIGLAS}

${ }^{\circ} \mathrm{C}$

AIR

ANCP

ASCL2

$\beta$-actina

$\mathrm{Be}$

$\mathrm{Bi}$

BI

BSA

SBW

Bx

CDKN1C

cDNA

CG

CGP

CIV

Co

$\mathrm{CO}_{2}$

COC

CpG

CpHs

$\mathrm{Cq}$

CTCF

d

DMR

DNA

Dnmts

dNTP

EDTA

EGF

EM

EX

FIV

FMRP
Graus Celsius

antisense IGF2R RNA

Associação Nacional de Criadores e Pesquisadores

Achaete-Scute Complex Homolog 2 (ou MASH2)

gene da $\beta$-actina

Blastocisto eclodido

Blastocisto inicial

Blastocisto

Bovine serum albunin (albumina sérica bovina)

Síndrome de Beckwith-Wiedemann

Blastocisto expandido

Ciclina-Dependent Kinase Inhibitor 1C (ou p57kip2)

DNA complementar

células germinativas

células germinativas primordiais

cultivo in vitro

cotilédones

dióxido de carbono

complexo cumulus-oócito

dinucleotídeo Citosina-fosfato-Guanina

citosinas seguidas de outras bases: CpT, CpA e CpC

Quantification cicle (ciclo de quantificação)

CCCTC-binding factor (Fator de Ligação CCCTC)

Dias

Diferencially Methylated Region (Região Diferencialmente Metilada)

ácido desoxirribonucleico

DNA citosina-5-metiltransferases

desoxinucleotídeo trifosfatado

ácido etilenodiaminotetraacético

Fator de crescimento epidermal

Embrionário

Extraembrionário

fertilização in vitro

Faculdade de Medicina de Ribeirão Preto da Universidade de São Paulo 


\begin{tabular}{|c|c|}
\hline FSH & hormônio folículo estimulante \\
\hline FZEA & Faculdade de Zootecnia e Engenharia de Alimentos \\
\hline g & Giros \\
\hline g & Gramas \\
\hline GAPDH & Glyceraldehyde-3-phosphate dehydrogenase \\
\hline$H 19$ & Imprinted Maternally Expressed Transcript \\
\hline H19DMR & Região diferencialmente metilada do gene $H 19$ (ICR1) \\
\hline HCG & gonadotrofina coriônica humana \\
\hline ICM & Inner cell mass (Massa celular interna) \\
\hline ICRs & Imprinting control regions (regiões controladoras de imprinting) \\
\hline ICSI & $\begin{array}{l}\text { Intracytoplasmic sperm injection (injeção intracitoplasmática de } \\
\text { espermatozóide) }\end{array}$ \\
\hline IGF2 & Insulin-Like Growth Factor 2 \\
\hline IGF2R & Insulin-Like Growth Factor 2 Receptor (Receptor do gene IGF2) \\
\hline $\mathbf{K b}$ & Kilobase \\
\hline $\mathrm{KCl}$ & cloreto de potássio \\
\hline KCNQ101T1 & KCNQ1 overlap trasncript \\
\hline KvDMR1 & segunda região controladora de imprinting \\
\hline KvLQT1 & Potassium Voltage-Gated Channel \\
\hline LGTC & Leiden Genome Technology Center \\
\hline LIT1 & Long intronic transcript 1 \\
\hline LME & Laboratório de Micromanipulação de Embriões \\
\hline LOI & Loss of Imprinting (perda de imprinting) \\
\hline LOS & Large offspring syndrome (Síndrome do bezerro grande) \\
\hline LUMC & Leiden University Medical Center \\
\hline M & Molar \\
\hline Mb & Mega base \\
\hline $\mathrm{MCl}$ & Massa celular interna \\
\hline $\mathrm{MgCl}_{2}$ & Cloreto de Magnésio \\
\hline MI & meiose I \\
\hline MII & meiose II \\
\hline MIV & maturação in vitro \\
\hline ml & Mililitro \\
\hline mm & Milímetros \\
\hline mM & Milimolar \\
\hline mRNA & RNA mensageiro \\
\hline
\end{tabular}




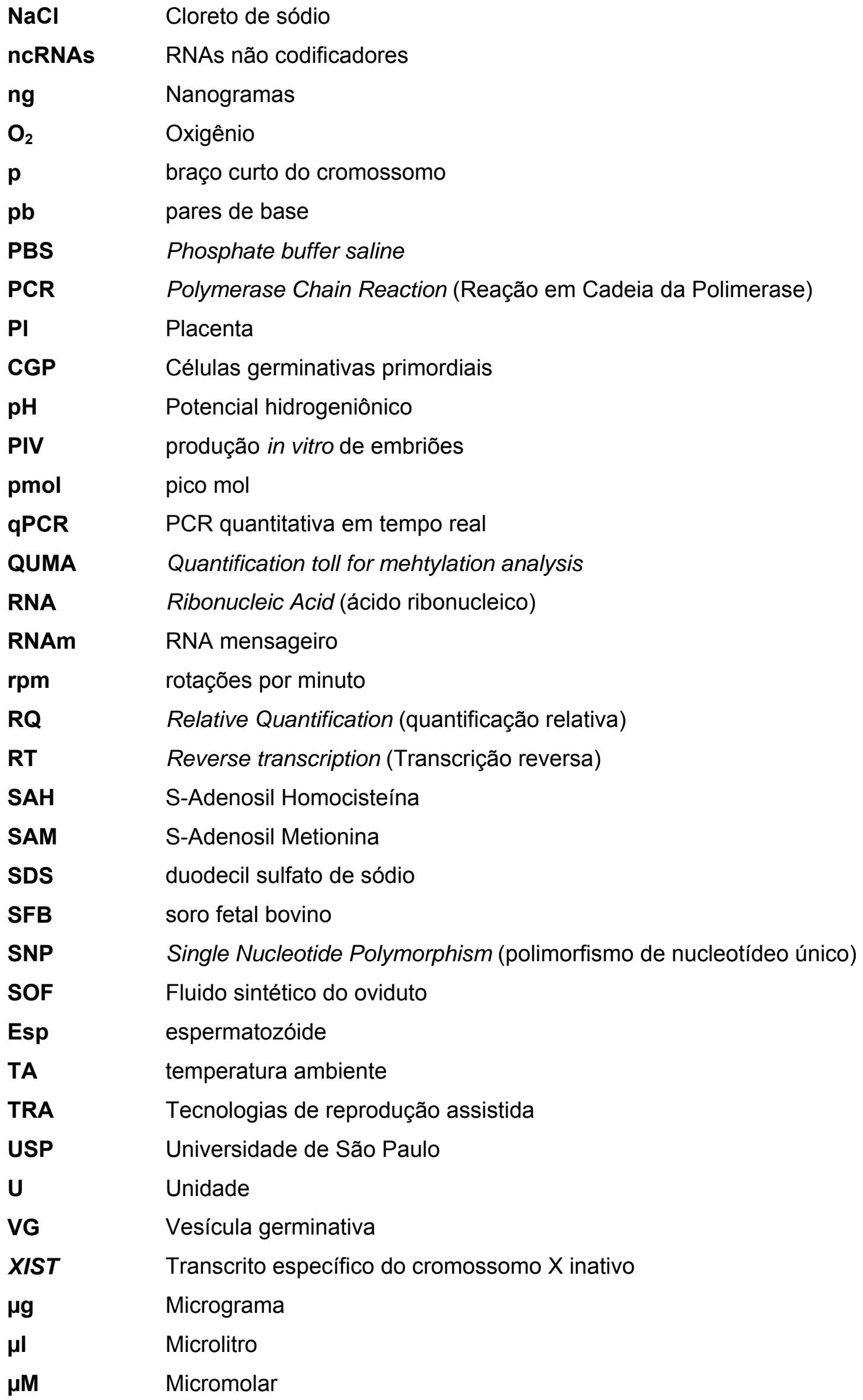




\section{LISTA DE FIGURAS}

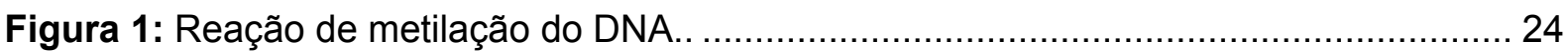

Figura 2: Esquema de metilação da H19DMR.......................................................... 26

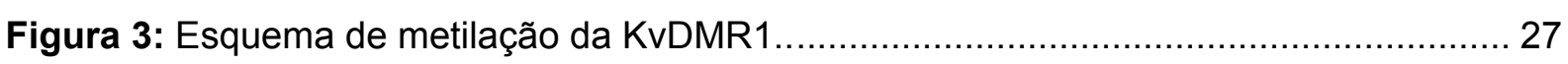

Figura 4: Reprogramação epigenética em camundongos................................................... 29

Figura 5: Complexo cumulus-oócito selecionados para maturação in vitro (LMEM)............ 38

Figura 6: Oócitos MII após 22-24 horas de maturação (LMEM) .......................................... 39

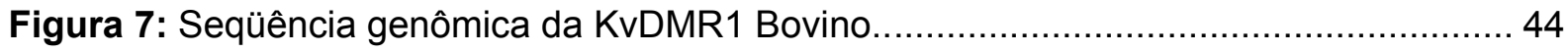

Figura 8: Seqüência genômica da região H19DMR de bovino........................................ 44

Figura 9: (a) Placenta e embrião bovinos de uma gestação de aproximadamente 49d. (b) Detalhe do embrião; (c) Cotilédone placentário. (d) Placenta humana com 12 semanas de

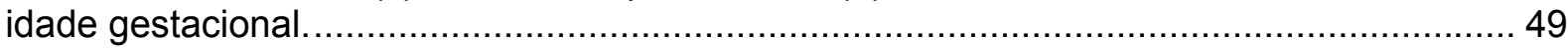

Figura 10: Seqüência genômica da KvDMR1 de Humano. ............................................... 51

Figura 11: Seqüência genômica da H19DMR de Humano............................................. 51

Figura 12: Oócitos MII (a e b) após a remoção das células do cumulus (aumento de

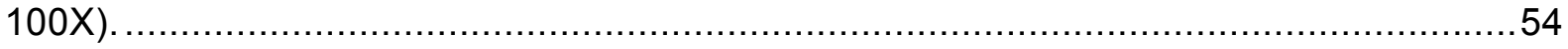

Figura 13: Morfologia do blastocisto durante o desenvolvimento embrionário pré-

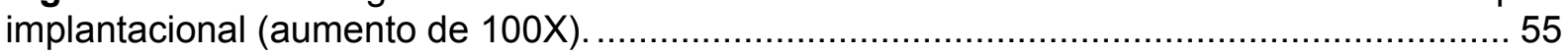

Figura 14: Amplificação da região KvDMR1 em gel de agarose (2,5\%) corado com brometo de etídio.

Figura 15: Amplificação da região H19DMR em gel de agarose (2,5\%) corado com brometo de etídio.

Figura 16: Alinhamento da sequência gerada a partir do seqüenciamento de nucleotídeos após a modificação do DNA com bissulfito com as sequências genômica e modificada...... 57

Figura 17: Padrão de metilação das regiões KvDMR1 e H19DMR em espermatozóide

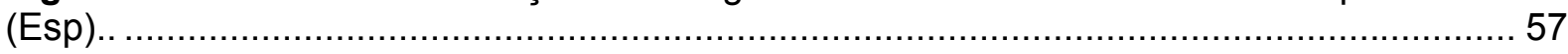

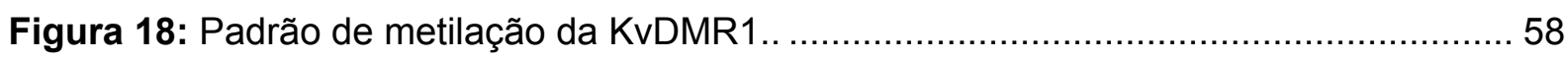

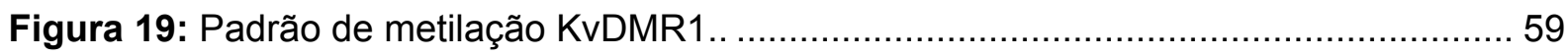

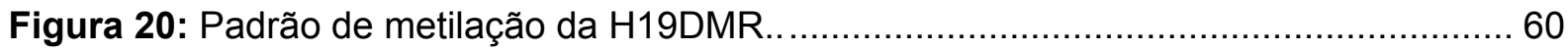

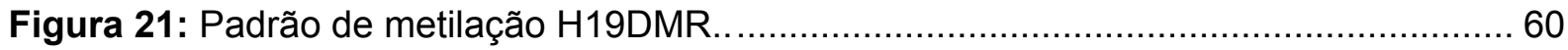

Figura 22: Expressão relativa dos genes LIT1 e IGF2 para as amostras analisadas. ......... 63 


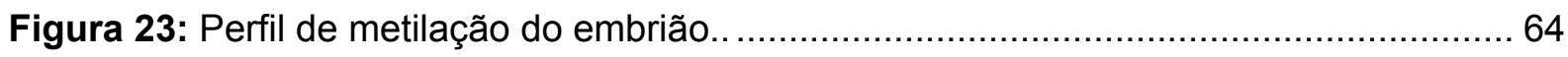

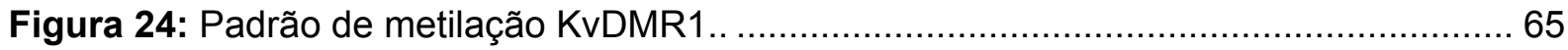

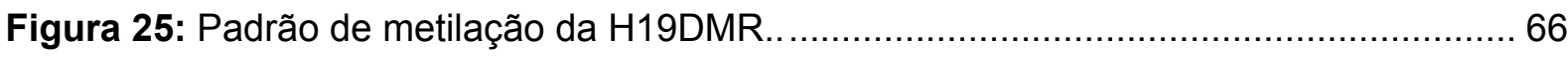

Figura 26: Amplificação da KvDMR1 e H19DMR em gel de agarose (2,5\%) corado com

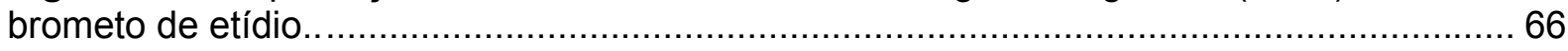

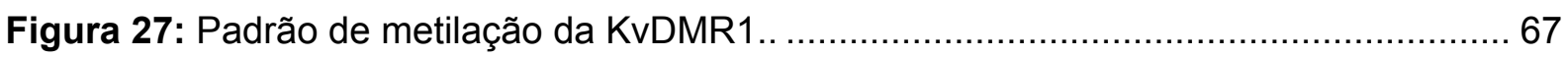

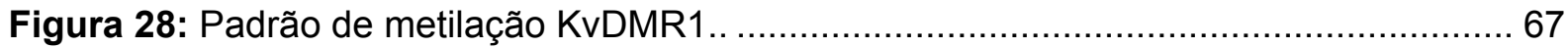




\section{LISTA DE TABELAS}

Tabela 1: Conjunto de primers a utilizados para PCR em tempo real.

Tabela 2: Ciclo de quantificação $(\mathrm{Cq})$ médio entre as triplicatas amostrais para os genes $\beta$ actina e GAPDH.

Tabela 3: Valores de RQ observados nas reações de PCR em tempo real para os genes em estudo.

Tabela 4: Resultados agrupados das análises de metilação e expressão. 63 


\section{SUMÁRIO}

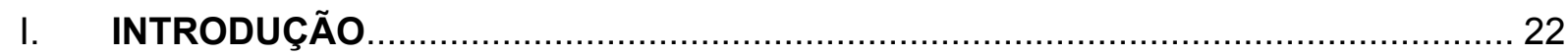

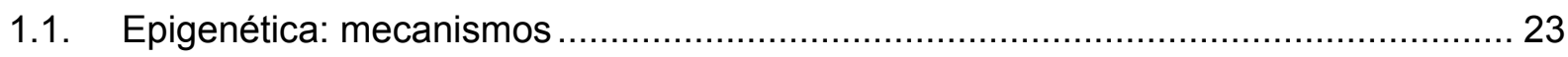

1.2. Imprinting genômico e Regiões Controladoras de Imprinting .................................. 24

1.3. Reprogramação genômica em mamíferos............................................................ 28

1.4. Produção de embriões bovinos in vitro e alterações epigenéticas ............................. 30

1.5. Placenta e imprinting genômico .................................................................................... 32

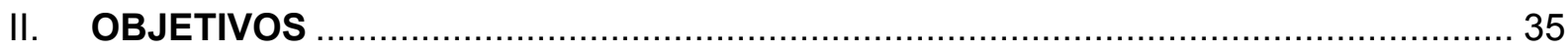

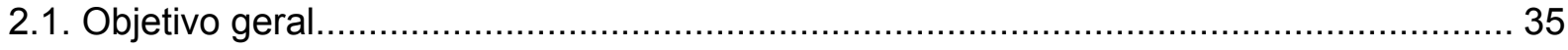

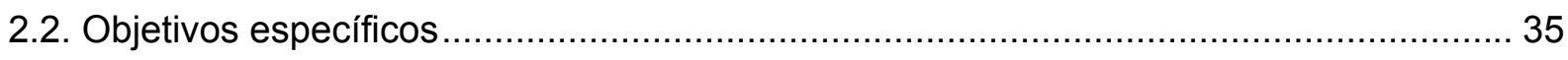

III. CASUÍSTICA, MATERIAL E MÉTODOS

3.1. PADRÃO DE METILAÇÃO DA KvDMR1 E H19DMR E EXPRESSÃO GÊNICA DIFERENCIAL EM OÓCITOS E EMBRIÕES PRÉ-IMPLANTAÇÃO BOVINOS .................. 37

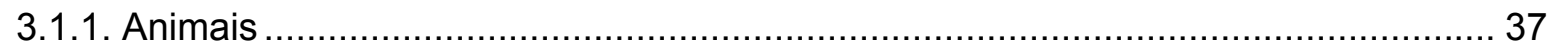

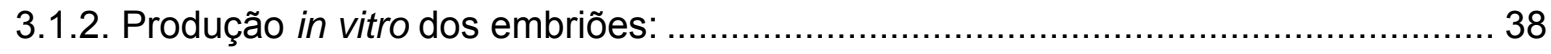

3.1.2.1. Segundo o protocolo do Laboratório de Micromanipulação de Embriões

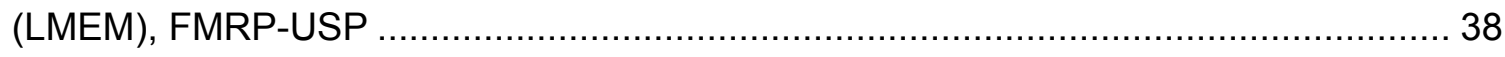

3.1.2.1.1 Coleta e maturação in vitro dos complexos cumulus-oócito........................... 38

3.1.2.1.2. Fertilização in vitro e cultivo dos embriões ................................................. 40

3.1.2.2. Segundo o protocolo do Laboratório do Prof. Dr. Bernard A. Roelen,

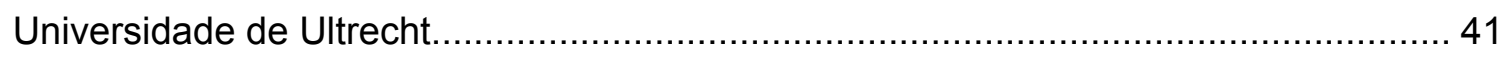

3.1.2.2.1. Coleta e cultura dos complexos cumulus-oócito......................................... 41

3.1.2.2.2. Fertilização in vitro e cultivo dos embriões ................................................... 41

3.1.3. Análise molecular: Seqüenciamento pós-modificação do DNA com bissulfito de

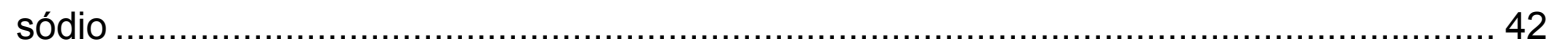

3.1.3.1. Extração do DNA e modificação por bissulfito de sódio. ................................ 42

3.1.3.2. Amplificação da KvDMR1 e H19DMR ......................................................... 43

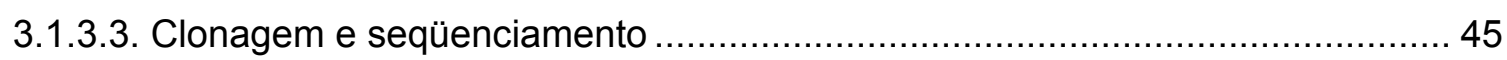

3.1.3.4. Alinhamento de seqüências e análises do padrão de metilação ...................... 46

3.1.4. Análise molecular: Expressão gênica ........................................................ 46

3.1.4.1. Purificação do RNA e síntese do cDNA ............................................................. 46

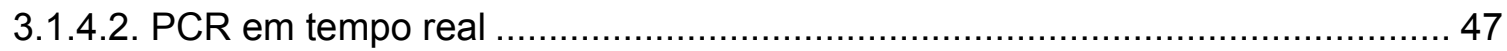

3.2. ANÁLISE COMPARATIVA DO PADRÃO DE METILAÇÃO DAS KvDMR1 e H19DMR 


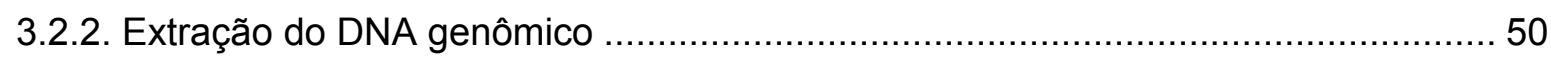

3.2.3. Sequenciamento pós-modificação com bissulfito de sódio ................................. 50

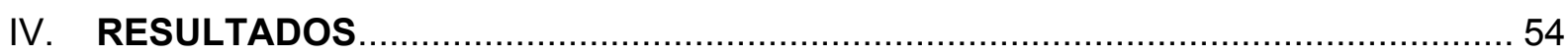

4.1. PADRÃO DE METILAÇÃO DA KvDMR1 E H19DMR E EXPRESSÃO GÊNICA DIFERENCIAL EM OÓCITOS E EMBRIÕES PRÉ-IMPLANTAÇÃO BOVINOS ................... 54

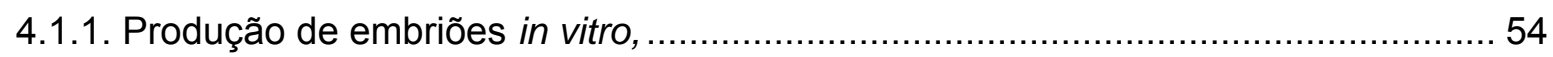

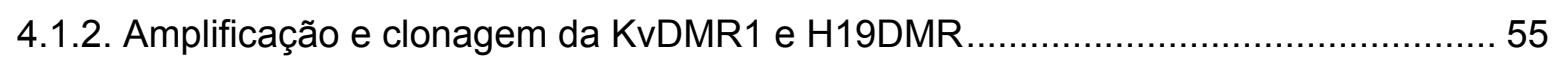

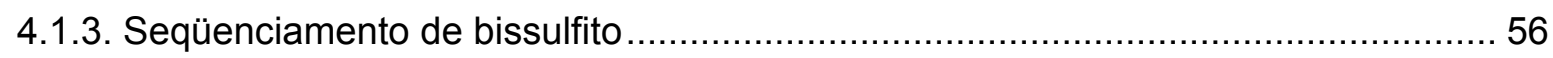

4.1.4. Padrão de metilação da região KvDMR1 ....................................................... 58

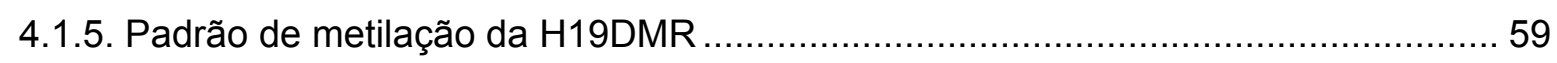

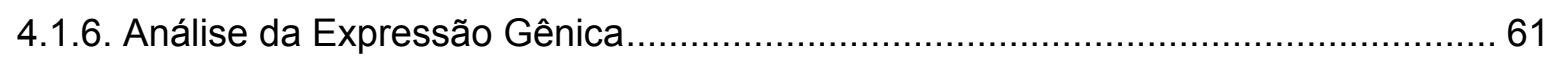

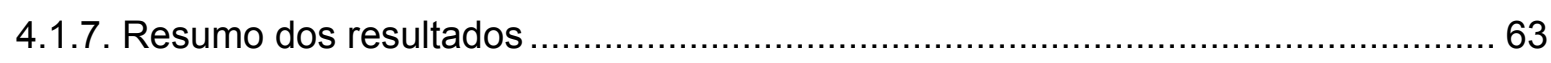

4.2. ANÁLISE COMPARATIVA DO PADRÃO DE METILAÇÃO DAS KVDMR1 E H19DMR

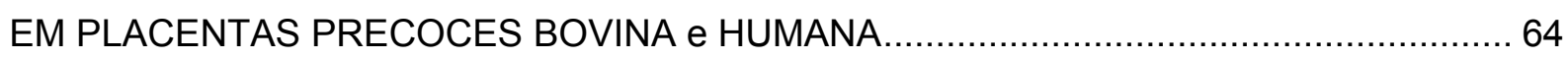

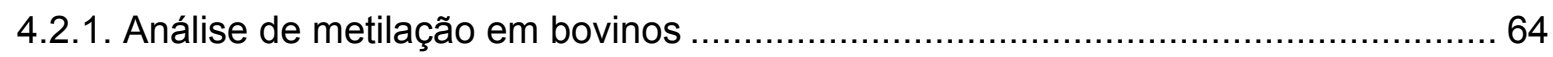

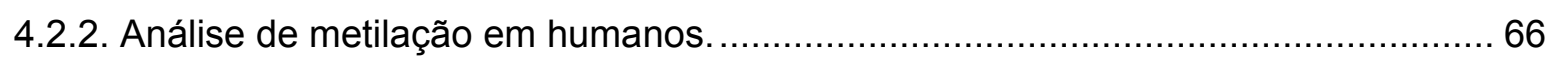

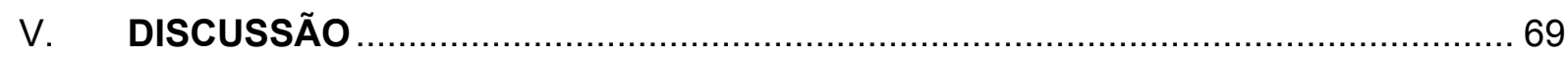

5.1. PADRÃO DE METILAÇÃO DAS REGIÕES KvDMR1 E H19DMR E EXPRESSÃO GENICA DIFERENCIAL EM OÓCITOS E EMBRIÕES PRÉ-IMPLANTAÇÃO BOVINOS .... 69 5.2. ANÁLISE COMPARATIVA DO PADRÃO DE METILAÇÃO DAS KVDMR1 E H19DMR EM PLACENTAS PRECOCES BOVINA E HUMANA ................................................. 74

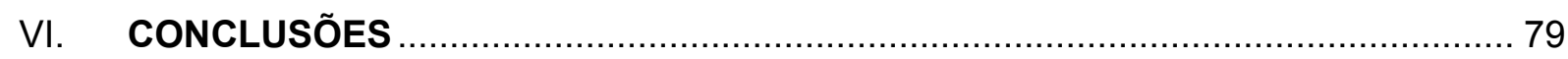

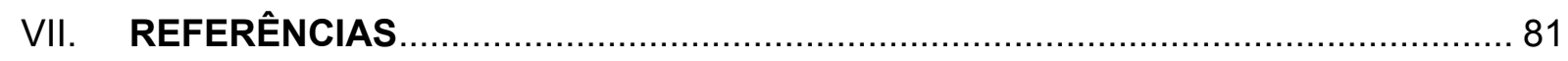

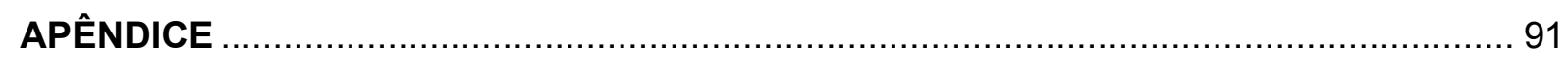

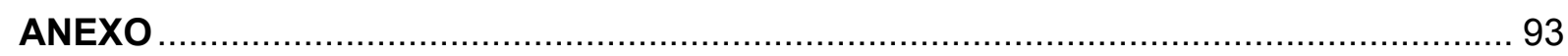


INTRODUÇÃO 


\section{INTRODUÇÃO}

As marcas epigenéticas são essenciais para o crescimento e desenvolvimento normal em mamíferos. O imprinting (marcação) genômico, modelo de processo epigenético, corresponde à expressão gênica alelo-específica dependendo da sua origem parental, sendo que esse estado monoalélico de expressão aumenta a susceptibilidade de mutações e epimutações, ao mesmo tempo em que permite um controle mais preciso da dosagem gênica para os principais reguladores do crescimento (Wagschal e Feil, 2006; Fowden et al., 2011).

Os genes marcados epigeneticamente desempenham um importante papel durante o crescimento e desenvolvimento embrionário, na diferenciação placentária e em processos neurocomportamentais (Reik et al., 2001), sendo que a perda de imprinting ou a expressão bialélica desses genes está associada a diversas doenças em humanos, incluindo anomalias neurogenéticas e de desenvolvimento, como as síndromes de BeckwithWiedemann (SBW) (Horike et al., 2000), Silver-Russell (Eggermann et al., 2006), PraderWilli e Angelman (Buiting, 2010). Devido ao importante papel desses genes em vias relacionadas ao crescimento, mudanças no seu padrão de metilação levam ao aparecimento de diversos tipos de tumores (Murphy e Jirtle, 2003; Das et al., 2009).

Em bovinos, alterações no padrão de metilação dos genes marcados estão relacionadas à fisiopatologia da síndrome do bezerro grande (LOS, do inglês, Large Offspring Syndrome) em ruminantes produzidos pelas tecnologias de reprodução assistida e transferência nuclear. Dentre as características mais marcantes dessa síndrome encontramse o aumento de peso ao nascimento e a placentomegalia (Young et al., 1998; Constant et al., 2006), fenótipo semelhante ao encontrado na SBW em humanos.

Além das similaridades fenotípicas dessas síndromes, a utilização do modelo animal bovino para estudos em humanos pode ser uma alternativa às pesquisas científicas envolvendo problemas éticos que impossibilitam o uso de material humano, como em estudos relacionados ao desenvolvimento embrionário e placentação. Ainda, no que diz respeito ao desenvolvimento embrionário pré-implantacional, o modelo bovino possui semelhanças ao de humanos quanto ao tamanho do genoma, ao padrão de migração dos microtúbulos durante a fertilização, tempo de ativação do genoma, necessidades metabólicas, interações com o meio de cultura e duração do desenvolvimento préimplantacional (Wrenzycki et al., 2005). 


\subsection{Epigenética: mecanismos}

A informação genética de uma célula diferenciada, na maioria dos casos, é a mesma proveniente do zigoto da qual é descendente. Apesar das células somáticas de um indivíduo serem geneticamente homogêneas, o que confere diferenças estruturais e funcionais é um programa diferencial de expressão gênica que tem inicio durante o desenvolvimento embrionário e permanece nas sucessivas mitoses. Essas diferenças são basicamente devido aos mecanismos epigenéticos de controle da expressão gênica que conferem a cada célula um fenótipo característico (Bird, 2002; Jaenisch e Bird, 2003).

O termo epigenética foi pela primeira vez utilizado por Conrad Waddington (1942) em estudos sobre a "canalização" do desenvolvimento, no qual o genótipo de um organismo responde ao ambiente de uma forma coordenada, em uma interação genótipo-genótipo e genótipo-ambiente, sendo que essa resposta pode ser fixada independente de efeitos mutacionais. Atualmente, epigenética pode ser definida como alterações estáveis na função gênica que não são explicadas por mudanças na seqüência do DNA. Os mecanismos epigenéticos atuam modificando a estrutura da cromatina e/ou de um determinado domínio cromossômico permitindo a ativação de alguns genes e o silenciamento de outros (Waddington, 1942; Haig, 2004).

Dentre os mecanismos epigenéticos de controle da expressão gênica, as modificações de histonas alteram a estrutura da cromatina pela adição de grupos químicos às caudas dessas proteínas que formam o nucleossomo. Essas modificações podem ser do tipo fosforilação, ubiquitinação e, principalmente, a metilação e acetilação, sendo que essas últimas ocorrem geralmente próximas à regiões promotoras e enhancers. Essas modificações geram um "código de histonas" que possui importante papel na modulação da transcrição, bem como no crescimento e diferenciação celular (Reik et al., 2003; Wang et al., 2009). Mais recentemente, a atuação de RNAs não codificadores (ncRNAs) têm sido incluída dentre os mecanismos epigenéticos, ativando ou silenciando genes em um determinado domínio cromossômico (como os longos ncRNAs KCNQ1OT1 e AIR) ou pela modulação da estrutura da cromatina como o ncRNA XIST (Mohammad et al., 2009) .

A metilação do DNA é o mecanismo epigenético mais estudado atualmente e consiste na ligação covalente de um radical metil ao carbono 5 de citosinas num contexto de um dinucleotídeo Citosina-fosfato-Guanina $(\mathrm{CpG})$ resultando na conversão de citosina para 5-metilcitosina na seqüência de DNA (Geiman e Muegge, 2010). Esse processo geralmente leva a um silenciamento gênico ou redução da sua atividade (Kiefer, 2007; Kurihara et al., 2008) e em mamíferos é catalisado por enzimas com ação demetilase conhecidas como DNA citosina-5-metiltransferases (Dnmts) (Figura 1). As Dnmts mantêm e reestabelecem a metilação do DNA, sendo que a Dnmt1 é responsável pela manutenção do padrão de 
metilação na replicação e em sua ausência ocorre a demetilação passiva. A metilação de novo é realizada, principalmente, pelas enzimas Dnmt 3a e 3b (Bestor, 2000).

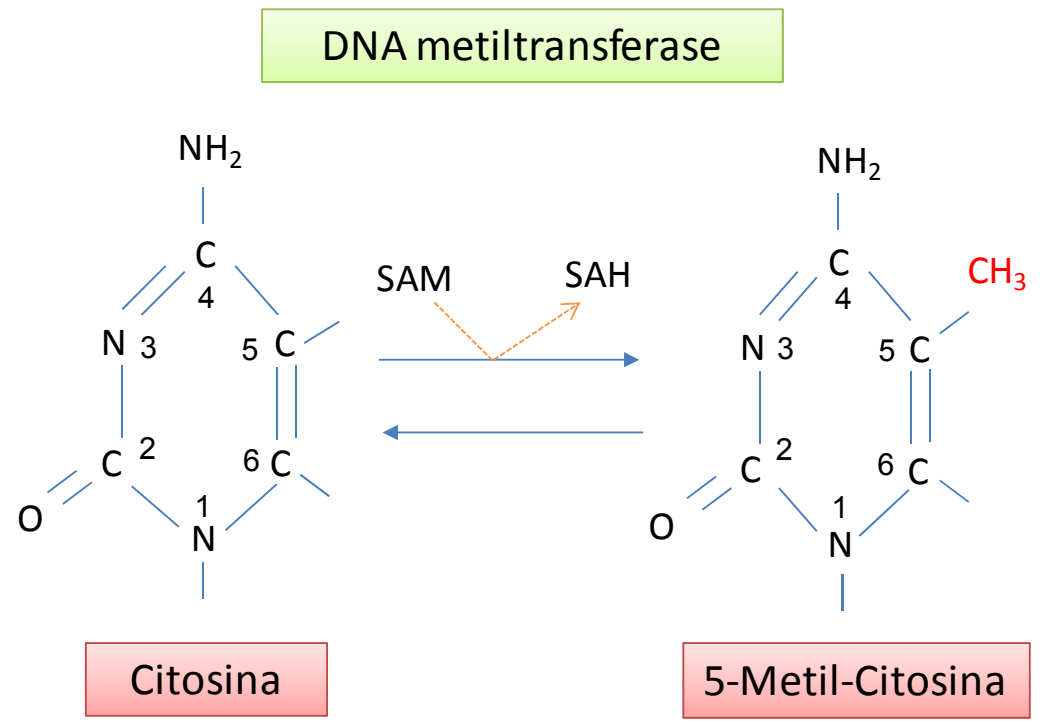

Figura 1: Reação de metilação do DNA. O radical metil é adicionado ao carbono 5 da citosina sob a ação da enzima DNA metiltransferase que utiliza como co-fator a S-Adenosil Metionina (SAM) como doadora do grupamento metil, sendo liberado o composto S-Adenosil Homocisteína (SAH).

A metilação do DNA, em conjunto com os demais mecanismos epigenéticos, é essencial para o desenvolvimento normal de um indivíduo, possuindo um papel fundamental nos processos epigenéticos que incluem a inativação do cromossomo $\mathrm{X}$, onde um dos cromossomos $X$ das células femininas é inativado como compensação de dose para os genes ligados ao $\mathrm{X}$, e no controle dos genes que sofrem o imprinting genômico, os quais são expressos dependendo da sua origem parental (Vassena et al., 2005). Além disso, a metilação do DNA auxilia na manutenção da estabilidade genômica, atuando no silenciamento de retrotransposons (Geiman e Muegge, 2010).

\subsection{Imprinting genômico e Regiões Controladoras de Imprinting}

O imprinting genômico é um processo epigenético característico de mamíferos placentários, em que apenas um membro de um par alélico é expresso dependendo da sua origem parental (Paoloni-Giacobino, 2006). A primeira evidência do imprinting genômico foi descrita por Surani et al. (1984) em experimentos com camundongos partenogenéticos, os quais apresentam uma falha no desenvolvimento a termo que não estaria relacionada com genótipo anormal dos genes ativados mas sim a uma situação citoplasmática anormal. 
Para provar esta hipótese, foram produzidos embriões partenogenéticos materno, contendo somente os dois pró-núcleos femininos (ginogenético), e partenogenético paterno, contendo somente pró-núcleos masculinos (androgenético). Neste estudo, foi observado que os embriões androgenéticos que chegavam ao final da gestação apresentavam desenvolvimento atrasado em comparação com o tecido extra-embrionário (placenta). Por outro lado, nos embriões ginogenéticos o tecido extraembrionário, responsável por dar suporte ao crescimento, apresenta um desenvolvimento incompleto e o embrião morre logo após a implantação. Esses resultados sugeriram que o imprinting do genoma ocorre durante a gametogênese, sendo que ambos os genomas materno e paterno são essenciais para o desenvolvimento normal de um indivíduo, incluindo os tecidos extraembrionários (Surani et al., 1984).

Cerca de 90 genes parecem sofrer imprinting em mamíferos (Ideraabdullah et al., 2008) sendo que o padrão de imprinting e a expressão dos genes marcados são espaço e tempo específicos e, em sua maioria, apresentam-se conservado entre humanos, alguns mamíferos e marsupiais. Uma importante característica desses genes é que geralmente eles são encontrados em clusters e estão espalhados por todo o genoma, facilitando a regulação da expressão gênica em um determinado domínio cromossômico (Reik et al., 2001; Ideraabdullah et al., 2008). Esse controle da expressão dos genes marcados é realizado por um ou vários elementos de DNA que operam em cis e são denominados Regiões Controladoras de Imprinting (ou ICRs, do inglês, Imprinting Controlling Regions). Essas regiões são diferencialmente metiladas (DMR, do inglês, Differentially Methylated Regions) entre os dois alelos dependendo da origem parental da qual é herdada, sendo que o seu estabelecimento ocorre durante o desenvolvimento da linhagem germinativa (Reik et al., 2001; Morgan et al., 2005; Ideraabdullah et al., 2008).

A SBW é caracterizada por hipercrescimento pré e pós-natal, está associada à malformações congênitas e predisposição a tumores. Dentre as causas moleculares dessa síndrome encontram-se as alterações de imprinting em dois domínios cromossômicos denominados ICR1 (onde se encontra a H19DMR) e ICR2 (com a KvDMR1), localizados na região 11p15 em humanos (Engemann et al., 2000; Cohen, 2005; Beatty et al., 2006). Essas regiões são controlam um cluster de genes importantes ao crescimento e desenvolvimento embrionário, e, em Bos taurus, domínios semelhantes a estas ICRs foram identificados no cromossomo 29 (Hori et al., 2010), que poderiam estar envolvidas com a LOS, que possui alterações fenotípicas de crescimento semelhante às da SBW.

A H19DMR está localizada na porção telomérica do cromossomo 11, a $2 \mathrm{~kb}$ upstream do promotor do gene H19 (do inglês, Imprinted Maternally Expressed Transcript) e controla o imprinting deste gene e do IGF2 (do inglês, Insulin-Like Growth Factor 2). O gene H19 expressa maternalmente um longo RNA não codificador que possui propriedades de repressão do crescimento, enquanto que o IGF2, cuja expressão é paterna, codifica para um 
fator de crescimento semelhante à insulina que estimula a progressão do ciclo celular. Ambos os genes são expressos durante o desenvolvimento embrionário sendo regulados negativamente no período pós-natal na maioria dos tecidos de camundongos e humanos (Ideraabdullah et al., 2008). Em bovinos, o IGF2 possui expressão paterna semelhante a humanos e camundongos (Curchoe et al., 2005; Lin et al., 2008)

A H19DMR é preferencialmente metilada no alelo paterno, sendo assim metilada no espermatozóide. Essa metilação, inativa o promotor do gene H19 e, consequentemente, impede a expressão desse gene no alelo paterno, sendo expresso maternalmente, facilitando a expressão paterna do gene IGF2 (Leighton et al., 1995). No entanto, o mecanismo de silenciamento ou ativação dos genes H19/IGF2 está relacionado, ainda, a uma competição por enhancer, determinada pelos níveis de metilação da ICR1 que possui propriedades de bloquear a ação de enhancers pela ligação de um insulador (Tilghman, 1999).

A H19DMR possui vários sítios de ligação à proteína insuladora CTCF (fator de ligação (CCTC) que atua restringindo a ação de enhancers nos seus promotores relacionados (Kim et al., 2007). A metilação no alelo paterno impede a ligação da proteína CTCF permitindo que enhancers downstream ao gene IFG2 possam atuar no seu promotor, promovendo a expressão deste gene. Inversamente, no alelo materno, a ausência de metilação permite a ligação do CTCF bloqueando a ação dos enhancers no promotor do IGF2 e permitindo que estes venham a atuar na expressão do gene H19 (Figura 2) (Bell e Felsenfeld, 2000; Edwards e Ferguson-Smith, 2007).

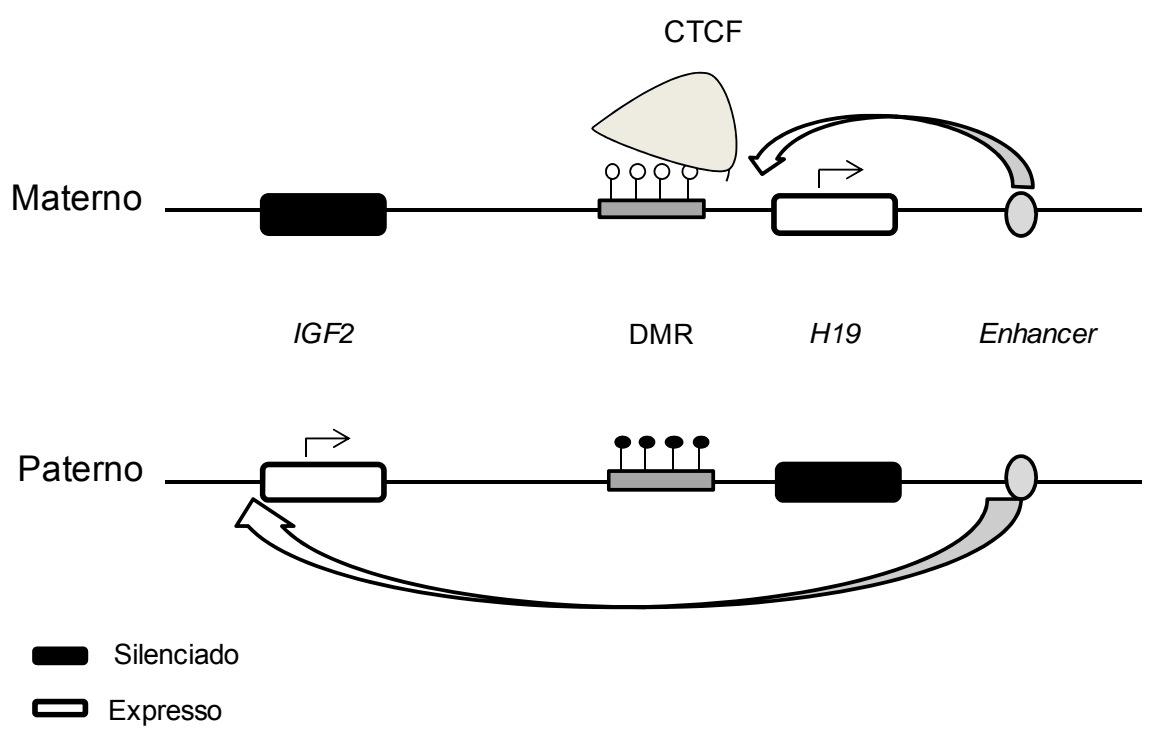

Figura 2: Esquema de metilação da H19DMR. A metilação no alelo paterno (círculos fechados) impede a ligação do insulador CTCF, facilitando a atuação dos enhancers no promotor do IGF2 promovendo a sua expressão. No alelo materno, a ICR1 não está metilada (circulos abertos), permitindo a ligação do CTCF bloqueando a atuação dos enhancers no IGF2, que promoverão a expressão do $H 19$. 
A segunda região controladora de imprinting (KvDMR1) está localizada na porção centromérica do cromossomo 11, mais precisamente, no íntron 10 do gene Canal de Potássio Voltagem Dependente (KVLQT1, do inglês, Potassium Voltage-Gated Channel) onde o alelo materno é metilado (Figura 3). Essa região controla o imprinting de vários genes, dentre eles o gene que codifica uma cinase dependente de ciclina, CDKN1C (do inglês, Ciclina-Dependent Kinase Inhibitor $1 C$ ou p57kip2), que em contraste ao IGF2, possui expressão materna e controla negativamente o ciclo celular e crescimento, podendo também atuar como supressor tumoral (Fitzpatrick et al., 2007; Ager et al., 2008). Nessa região está localizado ainda o promotor do gene que codifica um transcrito antisense ao gene KVLQT1 (ou KCNQ1) denominado KCNQ1OT1 (do inglês, KCNQ1 overlap trasncript 1,) conhecido também como LIT1 (do inglês, Long intronic transcript 1) cuja expressão é paterna, podendo atuar como um oncogene, semelhantemente ao IGF2, quando sua expressão está alterada (Mitsuya et al., 1999; Horike et al., 2000). Segundo Arima et al (2005) o gene LIT1 controla negativamente a expressão do gene CDKCN1 em cis.

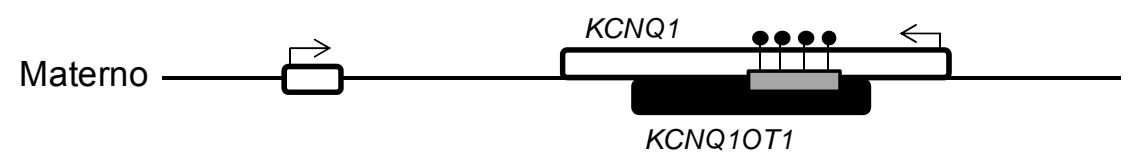

CDKN1C
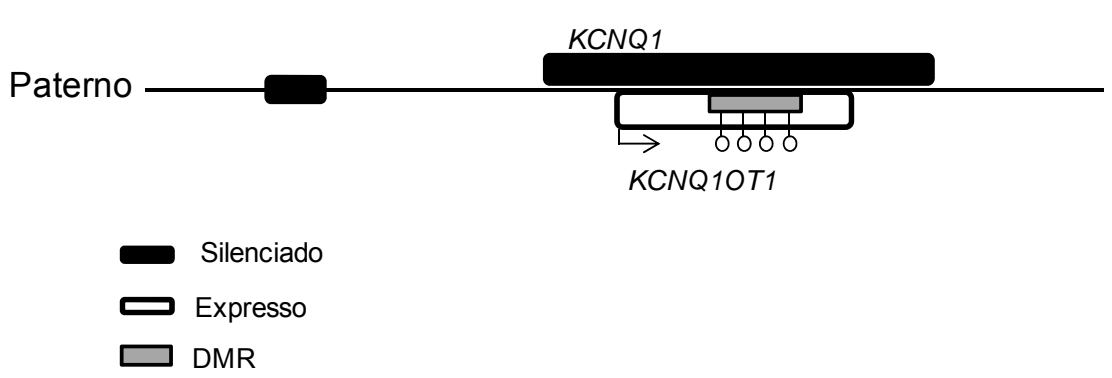

Figura 3: Esquema de metilação da KvDMR1. A metilação materna (círculos fechados) no intron 10 do gene KCNQ1OT1 (LIT1) impede a expressão desse gene, enquanto que os genes, CDKN1C e KCNQ1 são maternalmente expressos. O alelo paterno do gene LIT1 não está metilado (círculos abertos), sendo paternalmente expresso, enquanto que os genes CDKN1C e KCNQ1 são silenciados.

O crescimento fetal é afetado pelos genes marcados epigeneticamente de maneira antagônica, na qual os genes paternalmente expressos promovem o crescimento celular e fetal, enquanto que os genes expressos maternalmente tentam suprimir esse crescimento, proporcionando o balanço gênico ideal para o desenvolvimento embrionário na expressão haplóide desses genes. (Jirtle e Weidman, 2007). 


\subsection{Reprogramação genômica em mamíferos}

No desenvolvimento de um organismo multicelular, cada célula e tecido possui um programa diferencial de expressão gênica regulado pelas modificações epigenéticas que se reflete em um fenótipo diferenciado para cada tipo celular que é mantido após a diferenciação. No entanto, durante o desenvolvimento e em situações de doenças, alguns tipos celulares passam por uma reprogramação epigenética, envolvendo o apagamento de algumas marcas e o estabelecimento e manutenção de novas assinaturas epigenéticas (Morgan et al., 2005).

A reprogramação epigenética ocorre em duas etapas da vida do indivíduo, durante o desenvolvimento da célula germinativa e no período pré-implantacional. O primeiro evento de reprogramação ocorre nas células germinativas primordiais (CGPs) masculinas e femininas, as quais possuem altos níveis de metilação quando comparadas com as células somáticas. Durante a migração das CGPs para a crista gonadal, as marcas epigenéticas parentais são apagadas, ocorrendo a demetilação global do genoma e, posteriormente, no período de maturação dos gametas, essas marcas são restabelecidas por um processo denominado metilação de novo (Morgan et al., 2005).

O restabelecimento das marcas de metilação parece ocorrer mais cedo nas células germinativas (CG) masculinas, no estágio de pró-espermatogônia, precedendo a reentrada das células na mitose e, posteriormente, meiose (Figura 4a). Diferentemente, a metilação de novo das CGs femininas ocorre após o nascimento, durante o crescimento dos oócitos, sendo que em algumas DMRs germinativas o estabelecimento do imprinting materno ocorre mais cedo ainda, durante o estágio de vesícula germinativa $(\mathrm{Vg})$, sendo que outras são completadas no oócito em metáfase II (Monk et al., 1987; Reik et al., 2001; Lucifero et al., 2004).

Um segundo evento de reprogramação ocorre durante a embriogênese, em que o genoma materno e paterno do zigoto totipotente sofre um apagamento das marcas epigenéticas parentais e um estabelecimento das marcas embrionárias para conferir o padrão de expressão gênica normal no desenvolvimento do embrião pré-implantação (Figura 4b) (Corry et al., 2009). Durante esse processo de demetilação global do genoma, a marcação parental de imprinting genômico das DMRs germinativas adquirida na gametogênese é geralmente protegida da reprogramação genômica que ocorre no período pré-implantacional, como observado na DMR do gene H19 que escapa dos eventos de demetilação (Reik et al., 2001; Surani, 2001; Morgan et al., 2005).. 

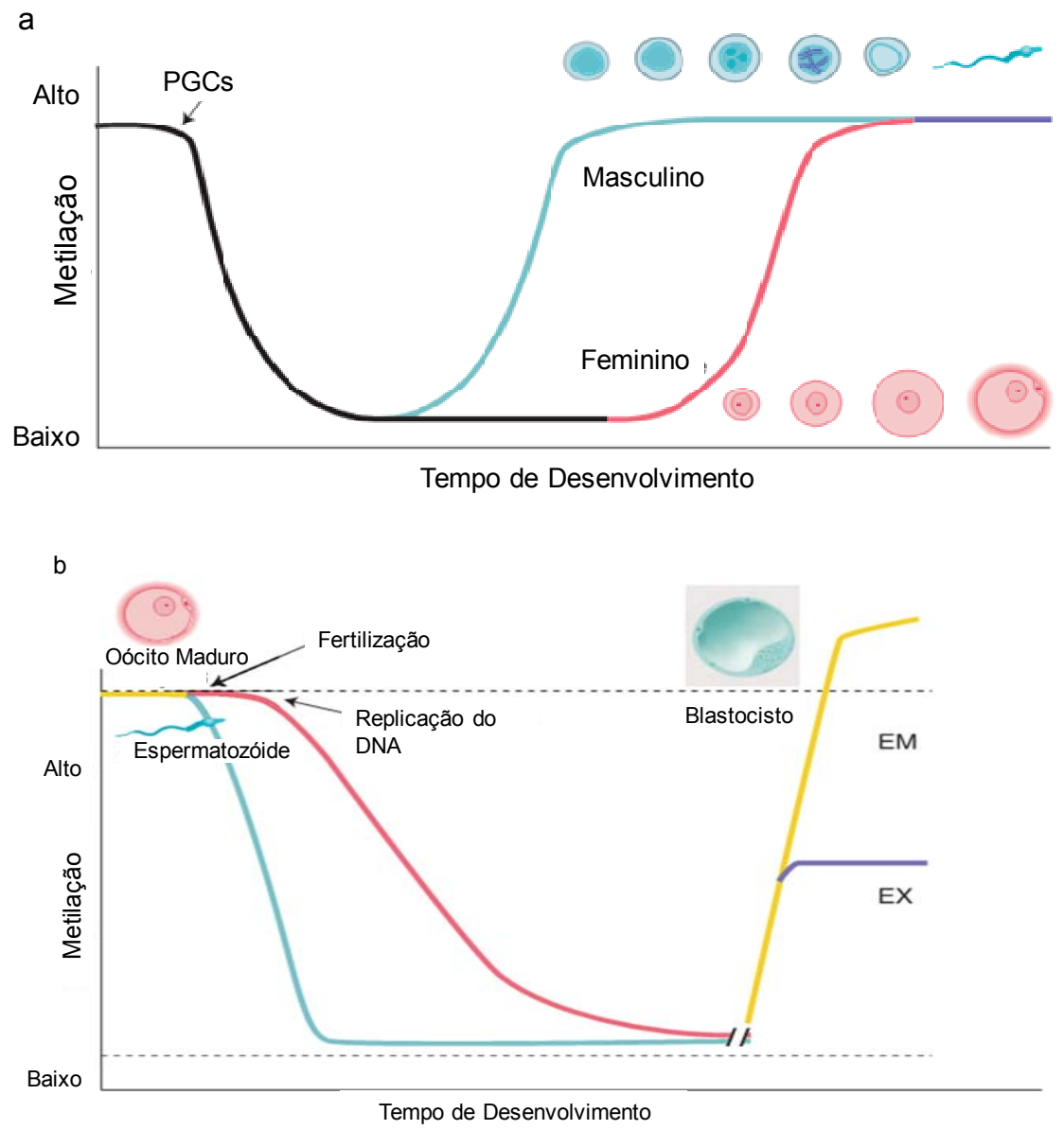

Figura 4: Reprogramação epigenética em camundongos. a) Reprogramação nas células germinativas. As CGPs são altamente metiladas e durante o início do desenvolvimento elas são gradualmente demetiladas. Nas CGs masculinas, a remetilação inicia no estágio de proespermatogônia e, nas CGs femininas, durante o crescimento dos oócitos. b) Reprogramação no embrião pré-implantação. O genoma paterno (azul) é demetilado por um mecanismo ativo logo após a fertilização e o genoma materno (rosa) é demetilado por um mecanismo passivo que depende da replicação do DNA. Ambos os genomas são remetilados por volta do período da implantação embrionária em diferentes proporções nas linhagens embrionária (EM) e extraembrionária (EX). A metilação dos genes que sofrem imprinting e de algumas sequências repetitivas (linha tracejada) não são removidas e os genes que não são metilados (linha tracejada) permanecem sem metilação (Reik et al., 2001)

Alguns estudos mostram que a reprogramação global do genoma é conservada em mamíferos eutérios, incluindo humanos, camundongos e bovinos (Dean et al., 2001). A reprogramação durante o desenvolvimento embrionário pode ocorrer de maneira passiva, quando a metilação não é mantida após a replicação, ou ativamente, quando a manutenção da metilação é requerida para garantir sua propagação após a replicação. Em camundongos, o mecanismo ativo parece ocorrer no genoma paterno, com a demetilação do pró-núcleo masculino logo após a fertilização (aproximadamente 4 horas). Por outro lado, no pró-núcleo materno a maior onda de demetilação se dá durante o desenvolvimento do 
embrião pré-implantação, sugerindo uma demetilação passiva (Mayer et al., 2000; Trasler, 2006). Em bovinos, no entanto, a demetilação passiva ocorre no estágio de 2 a 4 células e um evento de metilação de novo ocorre no estágio de 10 a 16 células, gerando altos níveis de metilação no trofoectoderma do blastocisto, o que não ocorre em camundongos, onde a metilação de novo é restrita à massa celular interna (MCI) do embrião (Dean et al., 2001).

\subsection{Produção de embriões bovinos in vitro e alterações epigenéticas}

Em bovinos, a produção in vitro de embriões (PIV) tem crescido muito nos últimos anos e tem sido utilizada, dentre outras finalidades, para pesquisas de base como na compreensão do desenvolvimento in vivo dessa espécie, no aprimoramento de tecnologias associadas, como a transferência nuclear e, ainda, como modelo para outras espécies, incluindo humanos. A PIV envolve várias etapas, dentre elas a maturação in vitro (MIV) e a fertilização in vitro (FIV) do oócito, bem como o cultivo in vitro (CIV) dos embriões até o estágio de blastocisto, em que o desenvolvimento embrionário pré-implantacional in vivo é simulado em microambientes que garantem o desenvolvimento in vitro (Thompson, 1997).

Apesar dos avanços na produção de embriões bovinos in vitro, com aprimoramento das técnicas utilizadas, este processo ainda é ineficiente, com cerca de $40 \%$ dos oócitos fertilizados chegando ao estágio de blastocisto, sendo que os que alcançam esse estágio geralmente estão comprometidos quanto à capacidade e competência. Os diferentes microambientes e a manipulação in vitro podem levar a sérios impactos sobre a fisiologia do desenvolvimento do embrião, visto que os embriões produzidos in vitro são relativamente inferiores aos produzidos in vivo com relação à morfologia, à criotolerância, ao metabolismo, ao perfil de expressão gênica e à taxa de prenhez pós-transferência (Farin et al., 2006; Lonergan e Fair, 2008).

Outro fato importante que vai de encontro com à ineficiência dessas tecnologias, é que em bovinos são utilizados reprodutores superiores com a finalidade de aumentar o valor genético do rebanho (Galli e Lazzari, 2008), diferentemente do que ocorre em humanos, em que essas tecnologias são usadas como tratamento de infertilidade para casais que não podem conceber naturalmente. No entanto, estudos em humanos e animais têm documentado que as metodologias usadas para a PIV, como a FIV e a Injeção intracitoplasmática de espermatozóides (ou ICSI, do inglês, Intracytoplasmic Sperm Injection), tem causado anomalias de desenvolvimento e crescimento embrionário, mesmo que morfologicamente os embriões pareçam viáveis (Khosla et al., 2001).

Bovinos produzidos in vitro e por transferência nuclear, apresentam com grande frequência anomalias de crescimento, que incluem, aumento de peso ao nascimento, 
aumento do tamanho dos órgãos internos e do cordão umblical e, placentomegalia (Young et al., 1998). Esses fenótipos de hipercrescimento caracterizam LOS, que é observada em outros ruminantes (Young et al., 1998) e camundongos (Li et al., 1998) produzidos pelas tecnologias de reprodução assistida (TRAs). Esses fenótipos são semelhantes à SBW que ocorre com grande incidência entre crianças concebidas pelas TRAs (Maher et al., 2003; Paoloni-Giacobino, 2006; Gomes et al., 2007).

A base molecular da LOS não está bem esclarecida, sendo que muitos estudos têm mostrado expressão aberrante dos genes que sofrem imprinting no fenótipo dessa síndrome. Young et al. (2001) mostraram redução do mRNA e da proteína do gene IGF2R (Receptor do gene IGF2) casado por uma perda da metilação materna da IGF2R DMR. Devido às semelhanças fenotípicas da LOS com a BWS em humanos, alguns estudos têm sugerido alterações de metilação das DMRs germinativas, H19DMR e KvDMR1, em especial, a hipometilação da KvDMR1 a qual foi observada em animais provenientes de FIV e de transferência nuclear (Couldrey e Lee, 2010; Hori et al., 2010).

As causas associadas às síndromes de hipercrescimento, como a LOS, envolvem diversos fatores, dentre eles a manipulação e a qualidade dos gametas, os meios de cultivo, os fatores de crescimento presentes no soro fetal ou liberados dos sistemas de co-cultura de células, como as células da granulosa (Thompson, 1997). Outro fator importante é o desenvolvimento oocitário, já que durante a oogênese, o gameta feminino permanece na prófase I da meiose I ( $\mathrm{MI})$, no estágio de vesícula germinativa $(\mathrm{Vg})$, por um longo período até o recrutamento pelos folículos antrais. A completa maturação nuclear é caracterizada por mudanças na cromatina que levam o oócito da prófase I para a metáfase II da meiose II (MII) preparando-o fisiologicamente para completar a segunda divisão celular após a fertilização (Marteil et al., 2009). A realização desses processos in vitro, bem como a hiperestimulação hormonal com altas doses de gonadotrofinas para indução da ovulação, podem alterar o imprinting de genes importantes ao desenvolvimento, tornando o embrião inviável (Niemitz e Feinberg, 2004).

As metodologias da PIV são empregadas em momentos cruciais da vida do indivíduo, durante o crescimento e desenvolvimento embrionário e a maturação oocitária, onde ocorre o estabelecimento e a manutenção do imprinting nos eventos de reprogramação epigenética na gametogênese e no inicio do desenvolvimento embrionário, aumentando os riscos de erros de imprinting e diminuindo a viabilidade do embrião (Sato et al., 2007; Anckaert et al., 2009).

Devido às semelhanças das síndromes de hipercrescimento em humanos e bovinos e a dificuldade de utilizar embriões humanos em pesquisas científicas, pelos problemas éticos enfrentados, os embriões bovinos são um excelente modelo experimental para estudos relacionados ao desenvolvimento (Wrenzycki et al., 2005). 


\subsection{Placenta e imprinting genômico}

A placenta é o primeiro órgão formado durante a gestação, é altamente especializado, e garante o crescimento e desenvolvimento normal do feto. Este órgão, é responsável por estabelecer uma interface vascular materno-fetal que garante a troca de nutrientes, gás e resíduos entre a mãe e o concepto (Rinkenberger et al., 1997; Gude et al., 2004). Tendo em vista a comunicação estabelecida entre a mãe e o feto pela placenta, este órgão parece ser um dos sítios mais afetados pelas forças da teoria do conflito (Wood e Oakey, 2006). A hipótese do conflito diz respeito a um investimento parental desigual na prole, em que o genoma paterno evolutivamente tenta maximizar o uso das reservas maternas para o seu descendente durante a gestação, enquanto que o genoma materno limita o uso dessas reservas em uma única gestação (Wood e Oakey, 2006; Jirtle e Weidman, 2007).

A manutenção do estado funcionalmente haplóide dos genes que sofrem imprinting é fundamental para o desenvolvimento normal do embrião e da placenta, estando diretamente relacionado com a transferência de nutrientes e a alocação das reservas materno-fetais (Fowden et al., 2011). A expressão alterada desses genes está relacionada a diversas doenças em humanos e animais que incluem alterações na morfologia e fisiologia da placenta. Dentre elas, as síndromes SBW, em humanos, e a LOS, em ruminantes e camundongos, além de alterações de crescimento no feto, apresenta morfologia alterada da placenta, onde é observado um aumento considerável do tamanho e peso deste órgão e, em bovinos, ainda é descrito uma redução no número de placentomas ( $\mathrm{Li}$ et al., 1998; Young et al., 2001; Constant et al., 2006). Alguns estudos mostram que as alterações de imprinting podem contribuir para a patogenia de algumas complicações gestacionais como a restrição de crescimento intrauterino (Diplas et al., 2009), pré-eclâmpsia (Yu et al., 2009) e alterações pós natal como a obesidade (Tycko, 2006), doenças cardiovasculares e diabetes mellitus tipo 2 (Wadhwa et al., 2009).

Apesar de a placentação variar de acordo com as espécies, diversos trabalhos sugerem que o padrão de imprinting é conservado entre as espécies de mamíferos placentários, em especial, primatas, roedores e ruminantes (Wagschal e Feil, 2006). No entanto, o mecanismo de controle e seu nível de metilação desses genes podem variar filogeneticamente (Bressan et al., 2009). O padrão de imprinting na placenta pode variar com relação a outros tecidos de um mesmo indivíduo, onde alguns genes são marcados especificamente na placenta, não sendo encontrado o mesmo padrão nos tecidos do embrião ou do indivíduo adulto (Wagschal e Feil, 2006). Além disso, a expressão dos genes marcados pode variar espacialmente e temporalmente na placenta (Coan et al., 2005). 
Em camundongos, um vasto número de genes possui imprinting específico da placenta, o que não ocorre em humanos, onde a expressão bialélica é mais comum principalmente em placentas coletadas no primeiro trimestre (Pozharny et al., 2010). Monk et al. (2006) analisaram alguns genes ortólogos em camundongos e humanos os quais estavam sob o controle da KvDMR1. Os autores observaram diferenças na expressão de alguns genes, onde alguns tiveram expressão monoalélica materna em camundongos e em humanos apresentaram expressão bialélica, no tecido fetal e nas amostras de placenta de $1^{\circ}$ trimestre e a termo. Por outro lado, genes localizados centromericamente, como o $C D K N 1 C$, apresentaram padrão de expressão monoalélica tanto para camundongos quanto para humanos, em todos os tecidos analisados.

A identificação do imprinting em diferentes espécies é necessária para o entendimento da evolução desse processo epigenético e para a compreensão dos mecanismos que levam a essa expressão alelo específica (Zaitoun e Khatib, 2008). A utilização do modelo bovino pode ser uma alternativa para estudos de imprinting em humanos, já que há evidências de vários genes cujo padrão de marcação é conservado entre essas duas espécies, inclusive na placenta, mesmo que esta apresente diferenças morfológicas e invasivas (Wagschal e Feil, 2006). Ainda, o período de gestação de humanos e bovinos é semelhante (em torno de nove meses) e a gestação geralmente é unifetal, em contraste com camundongos, onde a gestação é de múltiplos fetos, aumentando a competição intrauterina, o que pode explicar a manutenção do grande número de genes com imprinting específico da placenta como uma pressão evolutiva em camundongos (Monk et al., 2006). 


\section{OBJETIVOS}




\section{OBJETIVOS}

\subsection{Objetivo geral}

Estudo das ICRs 1 e 2 em oócitos, embriões e placentas precoces.

\subsection{Objetivos específicos}

Verificar o padrão de metilação da KvDMR1 e da H19DMR em oócitos bovinos maturados e não maturados in vitro;

Verificar o padrão de metilação da KvDMR1 e da H19DMR em embriões nos estágios de blastocisto inicial e expandido bovinos obtidos por FIV;

Verificar o padrão de expressão dos genes LIT1 e IGF2 em oócitos bovinos maturados e não maturados in vitro;

Verificar o padrão de expressão dos genes LIT1 e IGF2 em embriões nos estágios de blastocisto inicial e expandido de bovinos obtidos por FIV;

Comparar o padrão de metilação da KvDMR1 e H19DMR com a expressão dos genes LIT1 e IGF2 nos oócitos e embriões pré-implantação bovinos;

Verificar o padrão de metilação da KvDMR1 e H19DMR em tecido embrionário e em cotilédones bovinos de gestação de 49 dias;

Verificar o padrão de metilação da KvDMR1 e H19DMR em tecido placentário humano com idade gestacional de 12 semanas;

Comparar o padrão de metilação das regiões KvDMR1 e H19DMR em placentas bovinas e humanas de primeiro trimestre. 
CASUÍSTICA, MATERIAL E MÉTODOS 


\section{CASUÍSTICA, MATERIAL E MÉTODOS}

O presente trabalho possui dois focos de estudo incluindo as regiões controladoras de imprinting (ICRs) 1 e 2 de bovinos. Dentre eles, o perfil de metilação das ICRs foi verificado em óocitos e embriões pré-implantação bovino produzidos pela técnica de FIV. Uma segunda análise foi realizada em placentas precoces de bovinos e humanos do sexo masculino com semelhante idade gestacional. Para melhor compreensão, a metodologia encontra-se subdividida em dois tópicos de acordo com os diferentes estudos realizados.

\subsection{PADRÃO DE METILAÇÃO DA KvDMR1 E H19DMR E EXPRESSÃO GÊNICA DIFERENCIAL EM OÓCITOS E EMBRIÕES PRÉ-IMPLANTAÇÃO BOVINOS}

\subsubsection{Animais}

As análises em oócitos e embriões pré-implantação bovinos foram realizados em duas etapas. Primeiramente, para conhecimento da técnica de fertilização in vitro (FIV) propriamente dita e do desenvolvimento embrionário pré-implantacional foi realizado um treinamento prático, onde a coleta de oócitos e a produção de embriões pré-implantação foram realizadas no Laboratório de Micromanipulação de Embriões (LMEM), no Departamento de Genética da Faculdade de Medicina de Ribeirão Preto da Universidade de São Paulo (FMRP-USP).

Os oócitos utilizados para as análises moleculares e para a FIV foram provenientes de fêmeas abatidas no matadouro de Barra Mansa, no município de Sertãozinho, SP, e as palhetas de sêmen foram concedidas pelo Programa de Melhoramento da Raça Nelore, da Associação Nacional de Criadores e Pesquisadores (ANCP). Durante os experimentos de FIV, foram selecionados como oócitos no estágio de vesícula germinativa $(\mathrm{Vg})$, logo após a coleta nos folículos, bem como oócitos após o processo de maturação in vitro (MIV). Durante o período pré-implantacional, foram selecionados os estágios de blastocisto inicial (Bi) e blastocisto expandido $(\mathrm{Bx})$, sendo que todo material produzido foi utilizado para otimização das técnicas moleculares.

Os experimentos foram também realizados em parte no laboratório da Profa. Dra. Susana M. Chuva de Sousa Lopes, do Departamento de Anatomia e Embriologia, do Centro Médico da Universidade de Leiden, Holanda. O material bovino holandês estudado (oócitos, espermatozóide e os blastocistos) foi concedido pelo Prof. Dr. Bernard A. J. Roelen, do 
Departamento de Saúde de Animais Domésticos da Faculdade de Medicina Veterinária da Universidade de Ultrecht, Holanda.

\subsubsection{Produção in vitro dos embriões:}

\subsubsection{Segundo o protocolo do Laboratório de Micromanipulação de Embriões (LMEM), FMRP-USP}

\subsection{Coleta e maturação in vitro dos complexos cumulus-oócito}

Para a maturação in vitro (MIV) dos complexos cumulus-oócitos (COCs), os ovários foram levados para o laboratório em solução salina ( $\mathrm{NaCl}$ 0,9\%) estéril, contendo penicilina (100 $\mathrm{Ul} / \mathrm{ml})$ e estreptomicina $(50 \mu \mathrm{g} / \mathrm{ml})$, em recipiente térmico a $35^{\circ} \mathrm{C}$. Em seguida, os oócitos foram lavados em nova solução salina $(\mathrm{NaCl} 0,9 \%)$ e foi realizada a coleta dos oócitos em folículos ovarianos de 2 a $8 \mathrm{~mm}$ de diâmetro, os quais foram aspirados com auxílio de seringa descartável acoplada a uma agulha de 18G. O líquido folicular foi depositado em uma placa de Petri para seleção dos COCs de grau 1 (Figura 5), que apresentam três ou mais camadas de células do cumulus compactas e citoplasma homogêneo sem granulações (Unceia, 1998).

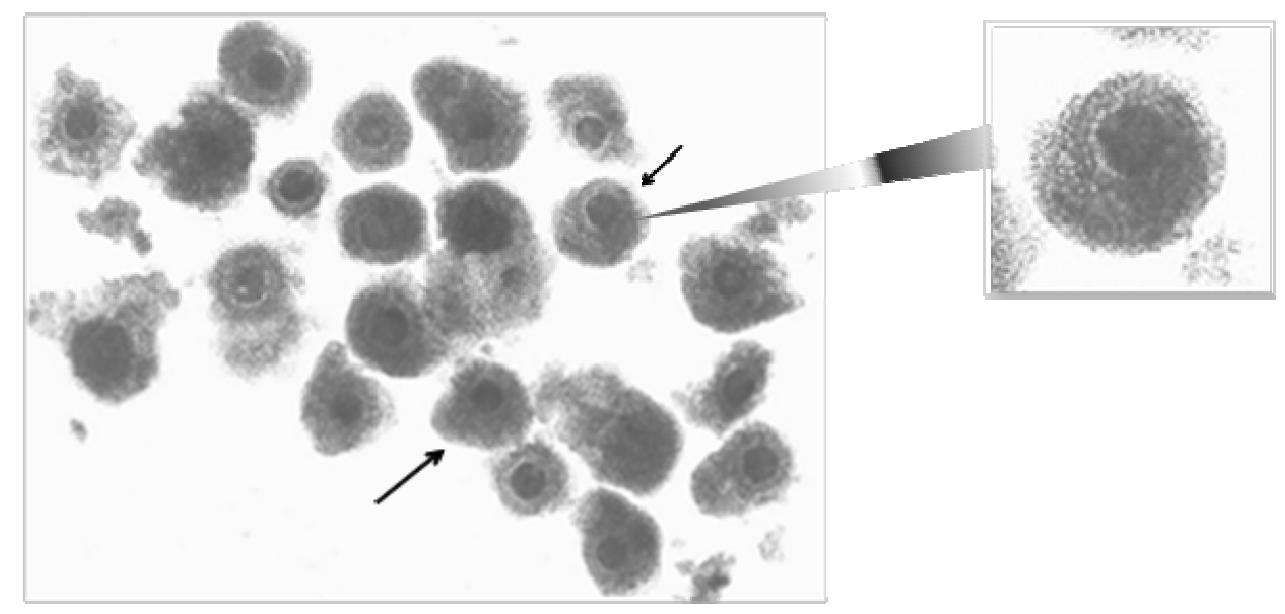

Figura 5: Complexo cumulus-oócito selecionados para maturação in vitro (LMEM).

Após a seleção dos COCs, foram coletados os oócitos $\mathrm{Vg}$ onde as células do cumulus foram removidas dos com auxílio de aparelho vortex, seguidas de pipetagem com pipeta Pasteur de diâmetro estreito de aproximadamente $0,5 \mathrm{~mm}$. Os oócitos $\mathrm{Vg}$ foram 
lavados em tampão PBS (Phosphate buffer saline) $1 \mathrm{X}\left(\mathrm{NaCl} 8,0 \mathrm{~g} / \mathrm{L} ; \mathrm{KCl}\right.$ 0,2 g/L, $\mathrm{Na}_{2} \mathrm{HPO}_{4}$ $1,44 \mathrm{~g} / \mathrm{L} ; \mathrm{KH}_{2} \mathrm{PO}_{4} 0,22 \mathrm{~g} / \mathrm{L}$ e $\left.\mathrm{pH} 7,0\right)$ e estocadas a $-80^{\circ} \mathrm{C}$ em grupos de 25 oócitos na mesma solução.

Os oócitos que seguiram para a MIV foram lavados duas vezes no meio de lavagem M199-HEPES (Gibco Laboratory, Grandlsland, NY, USA) suplementado com 0,2 mM de Piruvato (Sigma Chemical Co., St. Louis, MO, USA), $50 \mu \mathrm{g} / \mathrm{ml}$ de Gentamicina (Sigma Chemical Co., St. Louis, MO, USA) e 10\% de Soro fetal bovino (SFB, Gibco Laboratory, Grandlsland, NY, USA). Em seguida, os oócitos foram lavados duas vezes no meio de maturação TCM199, suplementado com Piruvato $(22 \mu \mathrm{g} / \mathrm{ml})$, Gentamicina $(50 \mu \mathrm{g} / \mathrm{ml})$ e 10\% de SFB, contendo ainda $0,5 \mu \mathrm{g} / \mathrm{ml}$ do Hormônio folículo estimulante ( $\mathrm{FSH}$, Folltropin® $\mathrm{V}-\mathrm{V}$, Bioniche Canada), $50 \mu \mathrm{g} / \mathrm{ml}$ de Gonadotrofina coriônica humana (HCG, Chorulon® 5000UI, Intervet Internacional B.V., Holanda) e $1 \mu \mathrm{g} / \mathrm{ml}$ de Estradiol (Sigma).

Os complexos cumulus oócitos (COCs) foram maturados em gotas de $100 \mu$ de meio de maturação cobertas com óleo mineral, contendo de 20 a 30 oócitos em cada gota. Os oócitos nas placas de maturação foram incubados a $38,7^{\circ} \mathrm{C}$ com $5 \%$ de $\mathrm{CO}_{2}$ e máxima umidade, durante 22-24h. Após a maturação, as células do cumulus sofreram um processo chamado de expansão e mucificação, formando uma matriz extracelular rica em ácido hialurônico (Zhuo e Kimata, 2001). Tais características dos COCs maturados podem ser observadas na figura 6.

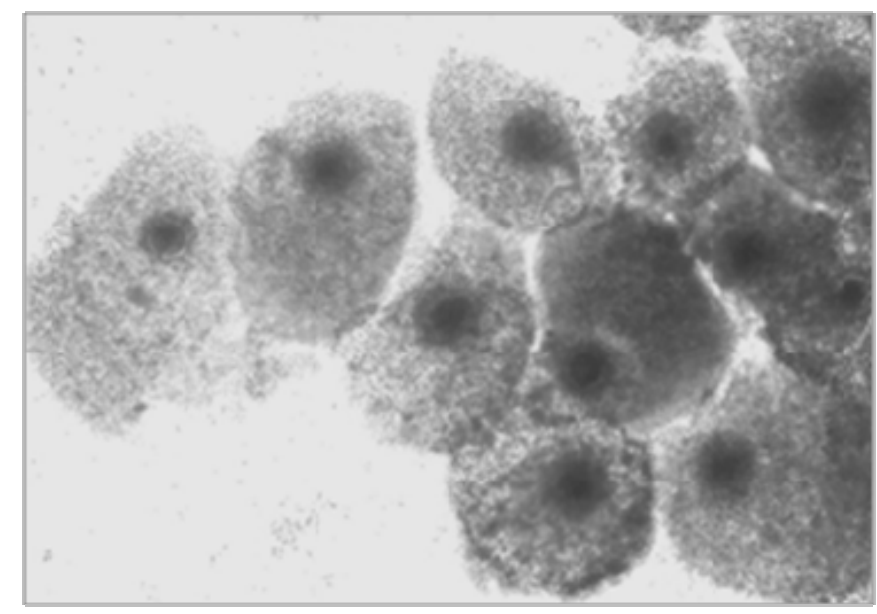

Figura 6: Oócitos MII após 22-24 horas de maturação (LMEM).

Os oócitos após a (MII) foram coletados e as células do cumulus foram removidas com solução de hialuronidase $(0,2 \%)$ (Hyaluronidase Type IV-S, Sigma) sob incubação por 15 minutos e auxílio de pipeta Pasteur de calibre estreito. Os oócitos MII foram estocados em PBS $1 \mathrm{X} \mathrm{a}-80^{\circ} \mathrm{C}$ até a utilização. 


\subsection{Fertilização in vitro e cultivo dos embriões}

Para a FIV, as palhetas de sêmen dos touros foram descongeladas em banho-Maria a $35^{\circ} \mathrm{C}$ e seu conteúdo foi colocado em um gradiente de Percoll (45 a 90\%) (Sigma) preparado com meio de lavagem, para obtenção de espermatozóides móveis (capacitação espermática) e remoção do diluidor do sêmen e do plasma seminal. Após 30 minutos de centrifugação, foram retiradas duas amostras de $5 \mu \mathrm{l}$ do pellet que foram diluídas uma em $250 \mu \mathrm{l}$ de água para contagem do número de espermatozóides em câmara de Neubauer. A outra alíquota do pellet foi diluída em $250 \mu \mathrm{l}$ de meio de fecundação para avaliação da motilidade espermática.

Após a capacitação espermática, o pellet de espermatozóides foi diluído em meio de fecundação [TALP suplementado com $10 \mu \mathrm{g} / \mathrm{ml}$ Heparina, $50 \mu \mathrm{g} / \mathrm{ml}$ piruvato, $50 \mu \mathrm{g} / \mathrm{ml}$ gentamicina, $6 \mathrm{mg} / \mathrm{ml}$ BSA (do inglês, Bovine serum albunin) com ausência de ácidos graxos e solução de PHE ( $2 \mu \mathrm{M}$ de penicilina, $1 \mu \mathrm{M}$ de hipotaurina e $0,25 \mu \mathrm{M}$ de epinefrina)], para ajustar seu volume a uma concentração de aproximadamente $2 \times 10^{6}$ espermatozóides $/ \mathrm{ml}$. Após a diluição, $10 \mu \mathrm{l}$ de espermatozóides foram adicionados a cada microgota da placa de fecundação e foram incubados a $38,7^{\circ} \mathrm{C}$ com $5 \%$ de $\mathrm{CO}_{2}$. Os oócitos MII foram lavados duas vezes em meio de fecundação, transferidos para as microgotas contendo os espermatozóides e submetidos à fecundação in vitro sob incubação a $38,7^{\circ} \mathrm{C}$ em ar com $5 \%$ de $\mathrm{CO}_{2}$ por 18 horas.

Após 168 horas de inseminação, no sétimo dia de cultivo in vitro, os supostos zigotos foram lavados em $600 \mu \mathrm{l}$ de meio de fecundação para remoção do excesso de células do cumulus por pipetagem e posteriormente foram lavados três vezes em meio de cultivo CR2aa (Rosenkrans e First, 1994). Os zigotos foram co-cultivados com camadas de células do cumulus em microgotas de $50 \mu \mathrm{l}$ de meio $\mathrm{CR}_{2}$ cobertas com óleo mineral.

No quarto dia de cultivo o excesso de células do cumulus foi removido e a taxa de clivagem dos embriões foi avaliada. Os embriões que apresentaram um aspecto de "amora", correspondente ao estágio de 16 a 32 células, foram removidos da placa.

No sétimo dia de cultivo pós FIV, foram coletados embriões no estagio de blastocisto inicial $(\mathrm{Bi})$ e expandido $(\mathrm{Bx})$, sendo os últimos estágios de desenvolvimento préimplantacional, os quais foram lavados três vezes em solução de PBS 1X e estocados a $80^{\circ} \mathrm{C}$ nesta solução, até a utilização. 


\subsubsection{Segundo o protocolo do Laboratório do Prof. Dr. Bernard A. Roelen, Universidade de Ultrecht}

\subsection{Coleta e cultura dos complexos cumulus-oócito}

Os ovários foram coletados em abatedouro local e transportados para o laboratório em até duas horas após a retirada. Em seguida, os oócitos foram lavados em solução salina ( $\mathrm{NaCl} 0,9 \%$ ) contendo $0,1 \%$ de penicilina-estreptomicina (Gibco BRL, Paisley, UK) e os folículos antrais com diâmetro entre 2 a $8 \mathrm{~mm}$ foram aspirados com o auxílio de uma bomba de sucção acoplada a uma seringa com agulha de calibre 19G. O líquido folicular aspirado foi coletado em tubos de $50 \mathrm{ml}$ e deixado em repouso por 15 minutos para sedimentação dos COCs.

Foram selecionados COCs contendo no mínimo três camadas de células do cumulus, os quais foram lavados no tampão HEPES-M199 (Gibco-BRL) e cultivados em grupos de 35-50 COCs em placa de cultura de quatro poços (Nunc A/S, Roskilde Denmark) contendo $500 \mu \mathrm{l}$ de meio M199 suplementado com 0,02 IU/ml FSH (Sioux Biochemical Inc, Sioux Center, IA, USA), 0,02 IU/ml LH (Sioux Biochemical Inc.), 7,71 $\mu \mathrm{g} / \mathrm{ml}$ Cisteamina, 10 $\mathrm{ng} / \mathrm{ml}$ Fator de crescimento epidermal (EGF) e 1\% Penicilina-estreptomicina (Gibco-BRL) à $39^{\circ} \mathrm{C}$ em atmosfera umidificada e com $5 \% \mathrm{CO} 2$.

Para a extração de DNA e RNA dos oócitos, as células do cumulus foram removidas por pipetagem com pipeta Pasteur de diâmetro estreito. Os grupos de 25 oócitos (Vg e MII) foram rapidamente congelados em nitrogênio líquido e estocados a $-80^{\circ} \mathrm{C}$ até a sua utilização.

\subsection{Fertilização in vitro e cultivo dos embriões}

Após 23 horas de maturação in vitro, os grupos de 35 COCs foram fertilizados in vitro como descrito por van Tol et al. (2008). Resumidamente, os espermatozóides de touros com comprovada fertilidade foram descongelados e foram adicionados aos COCs na concentração de 0,5x106 células $/ \mathrm{ml}$. Foi adicionado também $20 \mu \mathrm{l}$ de Heparina $(10 \mu \mathrm{g} / \mathrm{ml}) \mathrm{e}$ $20 \mu \mathrm{l}$ de solução de PHE contendo $20 \mu \mathrm{M}$ Penicilamina-d, $10 \mu \mathrm{M}$ Hipotaurina e $1 \mu \mathrm{M}$ Epinefrina. Após 20 horas de incubação, as células do cumulus foram removidas dos supostos zigotos em aparelho vortex durante 3 minutos. Os zigotos foram cultivados em grupos de 10 em gotas de $20 \mu \mathrm{l}$ de meio SOF (Fluido sintético do oviduto) suplementado com aminoácidos essenciais e não essenciais e 0,1\% de BSA. 
As gotas foram cobertas com óleo mineral (Reproline medical $\mathrm{GmBH}$, Rheinbach, Germany) e incubadas a $39^{\circ} \mathrm{C}$ em atmosfera umidificada contendo $5 \% \mathrm{CO}_{2}$ e $7 \% \mathrm{O}_{2}$, sendo este considerado o $1^{\circ}$ dia de desenvolvimento embrionário pré-implantacional. Os embriões no estágio de blastocisto inicial foram coletados no dia 7 e os embriões no estágio de blastocisto expandido foram coletados no dia 8 após a FIV.

\subsubsection{Análise molecular: Seqüenciamento pós-modificação do DNA com bissulfito de sódio}

\subsubsection{Extração do DNA e modificação por bissulfito de sódio.}

Para a extração de DNA, os grupos de oócitos Vg e MIl e os blastocistos Bi e Bx foram submetidos a uma lise celular. $\operatorname{Em~} 50 \mu \mathrm{l}$ de solução de lise $(0,5 \mathrm{M} \mathrm{KCl} ; 0,11 \mathrm{M}$ Tris$\mathrm{HCl} \mathrm{pH} \mathrm{8,3;0,1} \mathrm{mg/ml} \mathrm{de} \mathrm{Gelatina;} 900 \mu \mathrm{l}$ NP40 e $900 \mu \mathrm{l}$ Tween, em um volume final de 200 $\mathrm{ml}$ ) foi adicionado $1 \mu \mathrm{l}$ de Proteinase K (Qiagen, Hilden Germany) na concentração de 20 $\mathrm{ng} / \mu \mathrm{l}$. A cada amostra foi adicionado $20 \mu \mathrm{l}$ da solução de lise e o material foi incubado a $55^{\circ} \mathrm{C}$ por 40 minutos seguidos de um passo de inativação da enzima à $95^{\circ} \mathrm{C}$ por 10 minutos sob agitação a $750 \mathrm{rpm}$ em agitador de microtubos Thermomixer comfort (Eppendorf). Da mesma maneira, o DNA de espermatozóide foi extraído como controle de modificação, devido a seu perfil de metilação ser conhecido para as DMRs estudadas, sendo hipometilado para a KvDMR1 e hipermetilado para a H19DMR.

O DNA extraído foi modificado pelo tratamento com bissulfito de sódio o qual permite a conversão in vitro das citosinas não metiladas presentes na molécula de DNA em uracilas. Durante a amplificação a Taq DNA polimerase reconhece a uracila como timina, a qual permanece no final da PCR no lugar das citosinas não metiladas. A análise do padrão de metilação é realizada pela presença das citosinas metiladas que permaneceram no DNA após a modificação (Herman et al., 1996). Para a conversão do DNA genômico, foi utilizado o EpiTec Bissulfite Kit (Qiagen, Hilden Germany), de acordo com especificações do fabricante. Resumidamente, todo volume de DNA proveniente da lise $(20 \mu \mathrm{l})$ foi diluído adicionando-se $20 \mu \mathrm{l}$ de água ultrapura livre de DNase/RNase (Qiagen, Hilden Germany) para que se completasse um volume de $40 \mu$ de solução contendo DNA, em seguida foi adicionado $85 \mu \mathrm{l}$ da mistura de bissulfito e $15 \mu \mathrm{l}$ do tampão de proteção ao DNA, correspondendo a um volume de $140 \mu \mathrm{l}$ de solução final.

A mistura foi estocada à temperatura ambiente e, posteriormente, foi levada ao termociclador onde passou por etapas de desnaturação e incubação de aproximadamente 5h para a modificação do DNA. Em seguida, as amostras foram centrifugadas brevemente e 
o DNA passou para um processo de purificação em que foram adicionados $560 \mu \mathrm{l}$ de tampão BL contendo $10 \mu \mathrm{g} / \mathrm{ml}$ de RNA carrier em cada amostra. Todo material foi transferido para uma coluna EpiTec spin e centrifugado à rotação máxima (10.000 x g) por 1 minuto. O eluato foi descartado e foram adicionados $500 \mu \mathrm{l}$ de tampão BW para lavar a coluna a qual foi centrifugada à rotação máxima por 1 minuto e o líquido sob a coluna foi desprezado.

Foram adicionados $500 \mu \mathrm{l}$ de tampão BD para a dessulfonação das amostras sob incubação por 15 minutos à temperatura ambiente $\left(15\right.$ a $\left.25^{\circ} \mathrm{C}\right)$. Em seguida, a coluna foi centrifugada por um minuto à rotação máxima e o eluato foi descartado, esse passo foi repetido uma vez. Para a remoção de qualquer resíduo líquido das amostras, a coluna foi centrifugada à rotação máxima $\left(10.000 \mathrm{x}\right.$ g) por um minuto e incubada por 5 minutos a $56^{\circ} \mathrm{C}$. As colunas foram transferidas para um novo tubo de $1,5 \mathrm{ml}$ onde foram adicionados $20 \mu \mathrm{l}$ de tampão EB para eluição do DNA sendo que esse passo foi repetido uma vez para obtenção de maior quantidade de material modificado.

\subsubsection{Amplificação da KvDMR1 e H19DMR}

O DNA modificado foi amplificado utilizando-se primers específicos para a KvDMR1 e H19DMR os quais não discriminam os alelos metilados dos não metilados. As seqüências para as regiões de estudo foram preditas por Rios (2007) em estudos prévios em nosso laboratório utilizando seqüências do UCSC Genome Bioinformatics (http://genome.ucsc. edu/) e os sítios CpGs foram determinados pelo programa MethyPrimer (Li e Dahiya, 2002).

De acordo com Rios (2007), a região H19DMR possui cerca de sete sítios de ligação à proteína CTCF, semelhante à de humanos no qual a metilação diferencial encontra-se no sexto sítio. Apesar deste sítio não se encontrar em uma ilha CpG (regiões ricas em CG correspondendo geralmente a $50 \%$ dos nucleotídeos) em bovinos, ele corresponde à região que é diferencialmente metilada em humanos. Para a KvDMR1, foi utilizada seqüência contig que já estava descrita, para a caracterização da seqüência do promotor do gene LIT1 a qual foi utilizada no presente trabalho.

Os primers usados para as análises de seqüenciamento foram: KvDMR1 forward 5'GTTATATATGAGGGGTAAGTTGG-3' e reverse 5'-AAACTAATACCRATACCACCCAAA-3', e H19DMR forward 5'-TTTGTTTTGGGTTGATTAAATAGATT-3' e reverse 5'CTAACCTATACAAACCAACAAAATC-3'. As regiões analisadas compreenderam 18 dinucleotídeos CGs para a KvDMR1 (206pb) e 10 para a H19DMR (186pb) (Figura 7 e 8 , respectivamente). 
cccgctcacctgcccgctcggaccctggggagggctgcacagagggccagacccttgtggaaagccac agatgttcctcagggtcactccggggttcacgacccttgtggaaagccacagatgttcctcagggtca ctccggggttcacggctacacatgaggggtaagctgggCGctgagtgCGccgCGggCGgggaaCGaat CCGatCGcaagggtggaCGctcagacCGctggggtgggggtggggtgaaggtggggtggatcagcata gCGtctgggCGgactgggCGgggtgtggcaCGtggCGctgggctCGcCGgccaatgCGagcctgggtg gcatCGgcatcagccctctcagccaatggcagagcgcggcacaccgctttccacaccgcggccaatcc gcgcagcggcacgtggcacgcccgcccctgcaggctatccaatcagct

$\mathrm{b}$

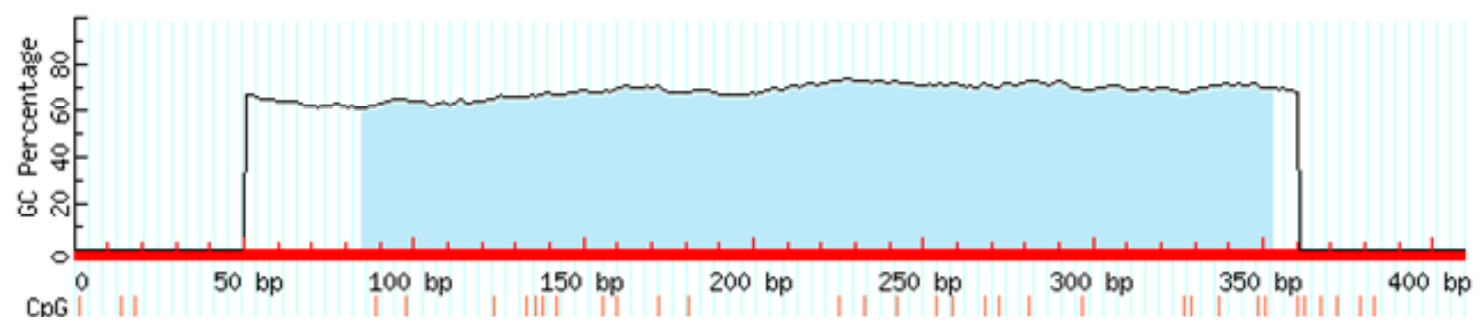

Figura 7: a) Seqüência genômica da KvDMR1 Bovino. Em azul: os dinucleotídeos CpGs analisados (18); Em vermelho: as regiões de pareamento dos primers utilizados; Grifado: sítio de restrição para enzima BstUI. b) Gráfico gerado pelo programa MethPrimer (Li e Dahiya, 2002) evidenciando a Ilha CpG (em azul) em fragmento correspondente a KvDMR1.

agccagcttcagagagagactctttctatgggaccttcagcagcctagggtgctgggcgccgccttgc catgggcatggggaattcgagggtcttctctctttgtcttgggctgaccaaatagacccatcacagtc cttgagtggagcccagggttgCGgatgtggggacagaagCGgctgCGaggtggcagtgcaggctcaca catcagCGgtggtggtttgcCCaCGCGgtggCCCGggtcCGtgCGCGCCcagccagagaccttgctgg tctgcacaggccagatatcacagtggcccatgagtgtcatggagggaacaggcactcatctgagcctc ctaaggtgccaagtcgggccacactgcagcttcagtcacaggttcc

Figura 8: Seqüência genômica da região H19DMR de bovino. Em vermelho: os dinucleotídeos CpGs analisados (10); Em azul: as regiões pareamento dos primers utilizados; Grifado: sítio de restrição para enzima BstUI.

As reações de amplificação foram realizadas em um volume final de $25 \mu \mathrm{l}$, contendo 1X GeneAmp PCR Buffer [500 mM KCl, $100 \mathrm{mM}$ Tris $\mathrm{HCl}(\mathrm{pH} 8,3), 15 \mathrm{mM} \mathrm{MgCl}$ ], dNTP (0,1 mM de cada nucleotídeo), primer 0,5 pmol (de cada), AmplitaqTaq ${ }^{\circledR}$ Gold DNA Polimerase (Applied Biosystems) $1 U$ e 1-3 $\mu \mathrm{l}$ de DNA modificado. As ciclagens de temperatura foram realizadas no termociclador programável $C-1000$ (Bio-Rad), as quais consistiram de um aquecimento inicial a $95^{\circ} \mathrm{C}$ por 5 minutos, seguido de 50 ciclos de desnaturação a $94^{\circ} \mathrm{C}$ por 45 segundos, pareamento a $59^{\circ} \mathrm{C}$ por 45 segundos, extensão a $72^{\circ} \mathrm{C}$ por 45 segundos e, posteriormente, uma extensão final de $72^{\circ} \mathrm{C}$ por 10 minutos. Os produtos de amplificação foram visualizados em gel de agarose $(2,5 \%)$ corado com brometo de etídeo (3\%). 


\subsubsection{Clonagem e seqüenciamento}

Os produtos de PCR foram diretamente clonados utilizando-se o TOPO TA Cloning ${ }^{\circledR}$ Kit (Invitrogen), de acordo com especificações do fabricante. As reações de ligação foram realizadas em $6 \mu \mathrm{l}$ de volume final, constituindo de 2 a $4 \mu \mathrm{l}$ do produto de PCR, $1 \mu \mathrm{l}$ do pENTER TOPO Vector e $1 \mu \mathrm{l}$ de solução salina (200 mM NaCl; $10 \mathrm{mM} \mathrm{MgCl}$ ), as quais foram incubadas por 5 minutos à temperatura ambiente e imediatamente resfriadas no gelo. Para a transformação bacteriana, foi utilizado E. coli TOP10 quimicamente competente sendo que $2 \mu \mathrm{l}$ da reação de ligação foram adicionados a $25 \mu \mathrm{l}$ de bactérias competentes. A reação de transformação foi incubada por 5 minutos no gelo e em seguida foi realizado um choque térmico de 30 segundos a $42^{\circ} \mathrm{C}$. Posteriormente, $250 \mu \mathrm{l}$ de meio SOC (Invitrogen) ( $2 \%$ tripitona, $5 \%$ de extrato de levedura, $\mathrm{NaCl}$ a $10 \mathrm{mM}, \mathrm{KCl}$ a $2,5 \mathrm{mM}, \mathrm{MgCl}_{2}$ a $10 \mathrm{mM}$, $\mathrm{MgSO}_{4} 10 \mathrm{mM}$ e $20 \mathrm{mM}$ de glicose) foram adicionados às bactérias transformadas as quais foram incubadas à $37^{\circ} \mathrm{C}$ por 1 hora sob agitação.

Após o período de incubação, $50 \mu \mathrm{l}$ das bactérias foram plaqueadas em meio seletivo LB (Luria Bertani) sólido (10 g de triptona, $5 \mathrm{~g}$ de extrato de levedura e $10 \mathrm{~g}$ de $\mathrm{NaCl}$ e $15 \mathrm{~g}$ ágar para um litro de solução) contendo kanamicina $(50 \mathrm{mg} / \mathrm{ml})$ e incubadas a $37^{\circ} \mathrm{C}$ overnight. Para a seleção das colônias positivas, clones individuais foram inoculados em $500 \mu \mathrm{l}$ de meio LB líquido (10 $\mathrm{g}$ de triptona, $5 \mathrm{~g}$ de extrato de levedura, $10 \mathrm{~g}$ de $\mathrm{NaCl}$ para um litro de solução) contendo kanamicina $(50 \mathrm{mg} / \mathrm{ml})$ e incubados a $37^{\circ} \mathrm{C}$ sob agitação por cerca de três horas. Em seguida, para a verificação da presença dos fragmentos de interesse foi realizada uma PCR com os mesmos primers utilizados para amplificar os fragmentos da KvDMR1 e H19DMR utilizando-se $1 \mu \mathrm{l}$ de cultura e seguindo as mesmas condições de amplificação e ciclagem de temperatura realizadas para a amplificação dos fragmentos a serem clonados (item 3.1.3.2.).

Os produtos de PCR foram seqüenciados no Leiden Genome Technology Center (LGTC) utilizando-se os primers forward e reverse para a KvDMR1 e somente o primer forward para a H19DMR visando abranger todos os sítios CpGs presentes nas regiões analisadas. Para o seqüenciamento de nucleotídeos, foi utilizado $1,0-1,5 \mu \mathrm{l}$ do produto de PCR, $1 \mu \mathrm{l}$ de primer $(10 \mu \mathrm{M})$ e água ultrapura para um volume final de $15 \mu \mathrm{l}$. As amostras foram enviadas ao LGTC onde foram realizadas as reações de precipitação e seqüenciamento utilizando o BigDye XTerminator ${ }^{\circledR}$ Kit (Applied Biosystems) e o seqüenciamento foi realizado utilizando-se o seqüenciador automático $A B I P R I S M \circledR 3730 x I$ Analyzer (Applied Biosystems). 


\subsubsection{Alinhamento de seqüências e análises do padrão de metilação}

Os resultados obtidos através do seqüenciamento dos clones positivos foram analisados utilizando-se o programa BioEdit Senquence Alignment Editor (Hall, 1999) que encontra-se disponível na internet (http://www.mbio.ncsu.edu/bioedit/bioedit.html) e possibilita a edição e o alinhamento de seqüências.

As análises de metilação foram realizadas utilizando-se o programa QUMA (Quantification Tool for Mehtylation Analysis) que possui uma interface na Internet para análises de seqüenciamento pós-modificação em dinucleotídeos CpG com bissulfito, em que é possível alinhar as seqüências genômica e modificada por bissulfito, verificar a qualidade da seqüência, quantificar e verificar o perfil de metilação em vários gráficos, bem como realizar análises estatísticas comparativas entre as amostras (Kumaki et al., 2008). Para verificar a qualidade das seqüências analisadas, os critérios de exclusão utilizados foram de 95\% como limite mínimo de $\mathrm{CpHs}$ (citosinas seguidas de outras bases: CpT, CpA e CpC) convertidas e $85 \%$ de identidade entre as seqüências genômica e os resultados de seqüenciamento.

\subsubsection{Análise molecular: Expressão gênica}

\subsubsection{Purificação do RNA e síntese do cDNA}

Para a análise de expressão gênica, o RNA foi extraído de três diferentes grupos (triplicata amostral) de oócitos GV (25) e MII (25) e de blastocistos Bi (10) e Bx (10), utilizando-se o RNasy Mini Kit (Qiagen, Hilden Germany). As células foram lisadas com $75 \mu \mathrm{l}$ do tampão RLT contendo $\beta$-mercaptoethanol (1:10) e com aparelho vortex. Em seguida, foi adicionado $75 \mu \mathrm{l}$ de etanol $70 \%$ e o material foi transferido para a coluna RNeasy MinElute Spin e centrifugado à $8.000 \times g$ por 15 segundos. Para lavar a coluna, foram adicionados $350 \mu$ do tampão RW1 e centrifugado a 8.000 × g por 15 segundos.

Para eliminar a contaminação por DNA genômico, o RNA foi tratado com $80 \mu \mathrm{l}$ de solução de DNase I (Qiagen, Hilden Germany), contendo $70 \mu \mathrm{l}$ de tampão RDD e $10 \mu \mathrm{l}$ de DNase $I$, sob incubação à temperatura ambiente por 15 minutos. Em seguida, foram adicionados $350 \mu$ do tampão RW1 e centrifugado a $8.000 \times g$ por 15 segundos. O eluato foi descartado, em seguida foram adicionados $500 \mu \mathrm{l}$ do tampão RPE e as amostras foram centrifugadas a $8.000 \times g$ por 15 segundos. Após a centrifugação foram adicionados $500 \mu \mathrm{l}$ de etanol $80 \%$ e centrifugado por 2 minutos a $8.000 \times$ g. Para secar a coluna, o material foi centrifugado por dois minutos à velocidade máxima $(10.000 \times g)$. Finalmente, para eluir o 
RNA, foram adicionados $14 \mu \mathrm{l}$ de água RNase free ao centro da coluna e centrifugado por 1 minuto a $8.000 \times g$.

Tendo como molde o RNA total, a síntese do DNA complementar (cDNA) foi realizada com o iScript cDNA Synthesis Kit (Bio-Rad). A transcrição reversa (RT) foi realizada com $4 \mu \mathrm{l}$ iScript reaction mix, $1 \mu \mathrm{l}$ iScript reverse transcriptase e $4 \mu \mathrm{l}$ de RNA em um volume final de $20 \mu \mathrm{l}$. Para excluir contaminação por DNA, foi realizada uma RTnegativa, nas mesmas condições citadas acima, porém sem a adição da enzima transcriptase reversa. As RTs, positiva e negativa, foram incubadas por 5 minutos à $25^{\circ} \mathrm{C}$, 30 minutos à $42^{\circ} \mathrm{C}$ e 5 minutos à $85^{\circ} \mathrm{C}$. $\mathrm{O}$ cDNA fita simples foi estocado à $-20^{\circ} \mathrm{C}$ até o uso na qPCR.

\subsubsection{PCR em tempo real}

Para a análise da expressão dos genes LIT1 e IGF2 foi utilizada a metodologia de RT-qPCR (Transcrição reversa associada a PCR quantitativo em tempo real). Como genesreferência foram utilizados os genes da $\beta$-Actina e o GAPDH (Glyceraldehyde-3-phosphate dehydrogenase). Para o desenho dos primers para os genes-alvo e para o gene da $\beta$-Actina, utilizou-se o programa Gene Runner v.3.05 (Hastings Software Inc.) de acordo com seqüências depositadas no GeneBank (http://www.ncbi.nlm.nih.gov/). Para a amplificação do GAPDH foi utilizada uma seqüência descrita por Van Tol et al. (2008). As seqüências dos primers utilizados estão representadas na tabela 1.

Tabela 1: Conjunto de primers a utilizados para PCR em tempo real.

\begin{tabular}{ccc}
\hline Genes & \multicolumn{1}{c}{ Sequencia 5' $^{\prime} \rightarrow \mathbf{3}^{\prime}$} & Produto $^{(\mathbf{p b})^{*}}$ \\
\hline$\beta$-actina & $\begin{array}{c}\text { CCGTCTTCCCGTCCATCGTG } \\
\text { GGATGCCTCTCTTGCTCTGA }\end{array}$ & 108 \\
\hline GAPDH & $\begin{array}{c}\text { AGGCATCACCATCTTCCAG } \\
\text { GGCGTGGACAGTGGTCATAA }\end{array}$ & 325 \\
\hline LIT1 & GGAGACAGAGGCCCAGAAG & 188 \\
& TAAGTGCCTGTGGAGCCTG & 116 \\
\hline IGF2 & CCCGCCAAGTCCGAGAGG & \\
\hline & CGCTGGGTGGACTGCTTC & \\
\hline
\end{tabular}

${ }^{*}(\mathrm{pb}):$ pares de bases

As qPCR foram feitas utilizando-se o sistema de detecção de seqüência CFX96 Touch $^{\text {TM }}$ Real-Time PCR Detection System (Bio-Rad). Como sistema de detecção foi utilizado o $S Y B R^{\circledR}$ Green Master Mix (Bio-Rad) e como método de quantificação foi utilizado 
o $\mathrm{C}_{\mathrm{q}}$ (Quantification cicle) comparativo ou quantificação relativa. As qPCRs foram feitas em triplicata tanto para o gene referência quanto para os genes-alvo.

A técnica de qPCR requer que a eficiência da reação, tanto para os genes alvo quanto para o gene referência, seja similar e alta. A eficiência da reação foi calculada de acordo com Livak \& Schmittgen (2001), por meio da construção de uma curva-padrão, gerada a partir da diluição serial do cDNA. Assim, antes da quantificação em tempo real, foram testadas as concentrações de primer e de DNA, que permitiram a melhor eficiência de reação tanto para os genes-alvo quanto para os controles endógenos. Foram testados quatro pontos de diluição (1:5).

As qPCR consistiram de uma mistura contendo $10 \mu \mathrm{l}$ de $S Y B R \circledast$ Green Master Mix (2X), 0,5 pmol de cada primer e $2 \mu \mathrm{l}$ de cDNA e as condições de amplificação para todos os sistemas foram: $95^{\circ} \mathrm{C}$ durante 3 minutos para ativação da Taq polimerase; seguidos de 40 ciclos de desnaturação à $95^{\circ} \mathrm{C}$ durante 15 segundos; pareamento à $60^{\circ} \mathrm{C}$ durante 30 segundos e extensão à $72^{\circ} \mathrm{C}$ por 45 segundos. Após 40 ciclos de amplificação todas as amostras foram submetidas à análise da curva de dissociação, a fim de validar a ausência de produtos não específicos e dímeros de primers. As amostras foram aquecidas com incremento de $0,5^{\circ} \mathrm{C}$ durante 30 segundos, partindo de $60^{\circ} \mathrm{C}$ até atingir o limite de $95^{\circ} \mathrm{C}$. Nas mesmas condições foi realizada uma amplificação com a RT-negativa de cada amostra utilizando o gene referência GAPDH.

Os resultados, obtidos com a análise de expressão dos alvos e da referência endógena, foram comparados diretamente e a normalização da expressão gênica foi feita por do meio método $2^{-\Delta \Delta \mathrm{Cq}}$ (Livak e Schmittgen, 2001), em que:

$$
\begin{gathered}
\Delta \mathrm{C}_{\mathrm{q}}=\mathrm{C}_{\mathrm{q}} \text { (alvo) }-\mathrm{C}_{\mathrm{q}} \text { (referência) } \\
\Delta \Delta \mathrm{C}_{\mathrm{q}}=\Delta \mathrm{C}_{\mathrm{q}} \text { (amostra) }-\Delta \mathrm{C}_{\mathrm{q}} \text { (calibrador) }
\end{gathered}
$$

Onde:

$\mathrm{C}_{\mathrm{q}}$ - ciclo onde a amplificação atinge o limiar de detecção do equipamento

Alvo - Gene Analisado

Referência - Controle Endógeno (GAPDH e $\beta$-actina )

Calibrador - amostra de células do cumulus 


\subsection{ANÁLISE COMPARATIVA DO PADRÃO DE METILAÇÃO DAS KvDMR1 e H19DMR EM PLACENTAS PRECOCES BOVINA e HUMANA.}

\subsubsection{Casuística}

Para uma análise comparativa entre o padrão de metilação da KvDMR1 e H19DMR em bovinos e humanos foram utilizadas amostras de placenta e feto bovino e amostras de placenta de humanos com idades gestacionais semelhantes e provenientes de embriões do mesmo sexo.

As amostras bovinas foram concedidas pelo grupo de pesquisa do Prof. Dr. Flávio Vieira Meirelles da Faculdade de Zootecnia e Engenharia de Alimentos da USP (FZEA/USP), das quais foram analisados quatro cotilédones e tecido embrionário (perna). A idade gestacional foi estimada utilizando-se a medida crânio-caudal (crown-rump length) disponível na internet (http://www.ansci.wisc.edu/jjp1/ansci_repro/lab/lab12_03/crownrump_analysis3.html). de Noden \& Lahunta (1990). A medida crânio-caudal foi de aproximadamente $5,5 \mathrm{~cm}$, sugerindo idade gestacional de $49 \mathrm{~d}$ de um animal de raça zebuína (Figura 9).

$\mathrm{b}$

a

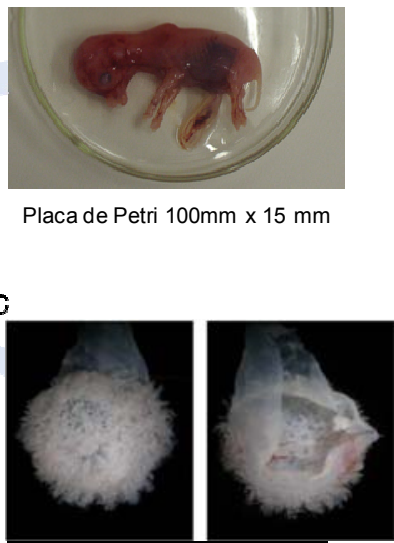

d

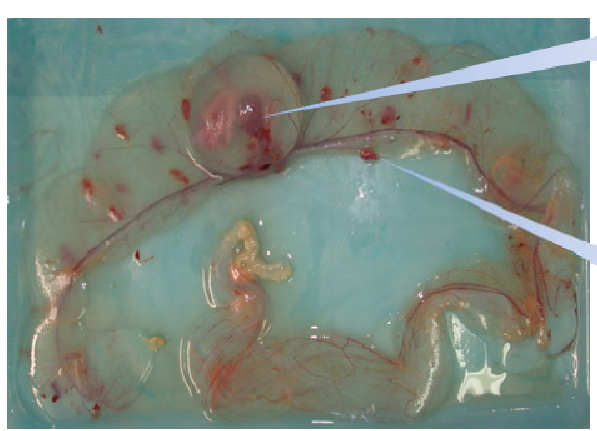

Aumento de 10X

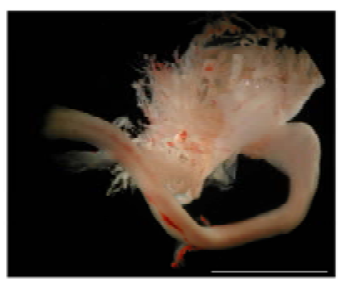

Aumento de $10 \mathrm{X}$

Figura 9: (a)Placenta e embrião bovinos de uma gestação de aproximadamente 49d. (b) Detalhe do embrião; (c) Cotilédone placentário. (d) Placenta humana com 12 semanas de idade gestacional.

As amostras de tecido placentário humano foram provenientes de quatro vilosidades provenientes de uma gestação de um feto masculino com 12 semanas de idade gestacional as quais foram concedidas pela Profa. Dra. Susana Chuva de Sousa Lopes do Centro Médico da Universidade de Leiden (Holanda) sob aprovação no comitê de ética do local. 


\subsubsection{Extração do DNA genômico}

O DNA genômico das amostras bovinas e humanas foi extraído pelo método de precipitação salina com $\mathrm{NaCl}$ modificado de Olerup e Zetterquist (1992) em que pequenos pedaços dos tecidos foram colocados em um microtubo de de $1,5 \mathrm{ml}$ onde foram adicionados $760 \mu \mathrm{l}$ de solução de lise contendo $160 \mu \mathrm{l}$ de tampão de proteinase $\mathrm{K}(0,375 \mathrm{M}$ de $\mathrm{NaCl} ; 0,12 \mathrm{M}$ EDTA), $40 \mu \mathrm{l}$ de SDS 10\% (Duodecil sulfato de sódio), $40 \mu \mathrm{l}$ de proteinase $\mathrm{K}(20 \mathrm{ng} / \mu \mathrm{l})$ e $520 \mu \mathrm{l}$ de água ultrapura livre de DNase/RNase. A solução foi incubada overnight $55^{\circ} \mathrm{C}$, a $750 \mathrm{rpm}$, no agitador Thermomixer comfort (Eppendorf) para completa a lise celular.

Após o período de incubação, as amostras foram resfriadas à $-4^{\circ} \mathrm{C}$ por 10 minutos. Em seguida foram adicionados $240 \mu \mathrm{l}$ de $\mathrm{NaCl}(5 \mathrm{M})$ e, para precipitação da proteína desnaturada, o material foi centrifugado a $10.000 \times \mathrm{g}$. Foram transferidos $400 \mu \mathrm{l}$ do sobrenadante para um novo tubo de microcentrífuga onde foi adicionado $1 \mathrm{ml}$ de etanol absoluto seguido de homogeneização por inversão. Para precipitação do DNA, as amostras foram estocadas por 30 minutos à $-20^{\circ} \mathrm{C}$ e posteriormente foram centrifugadas a $10.000 \times \mathrm{g}$ em centrífuga refrigerada $\left(0^{\circ} \mathrm{C}\right)$. $\mathrm{O}$ sobrenadante foi descartado após a centrifugação e foi adicionado $1 \mathrm{ml}$ de etanol $70 \%$ (gelado) para lavar o DNA. O material foi centrifugado a 10.000 x $g$ por 5 minutos e o sobrenadante foi novamente descartado. Para evaporação de resíduos de etanol, o pellet de DNA foi incubado à temperatura ambiente por 30 minutos e posteriormente foi ressuspendido em $50 \mu \mathrm{l}$ de água livre de DNase/RNase.

\subsubsection{Sequênciamento pós-modificação com bissulfito de sódio}

Para as análises de metilação, o DNA genômico foi modificado utilizando-se o EpiTec Bissulfite Kit (Qiagen, Hilden Germany) seguindo protocolo do fabricante, em que 10 $\mu \mathrm{l}$ de DNA $(1 \mu \mathrm{g})$ foram adicionados em $10 \mu \mathrm{l}$ de água para um volume de $20 \mu \mathrm{l}$ de solução. Em seguida, foram adicionados $85 \mu \mathrm{l}$ da solução de bissulfito e $35 \mu \mathrm{l}$ do tampão de proteção ao DNA totalizando um volume final de $140 \mu \mathrm{l}$. As reações de modificação foram incubadas

a temperatura ambiente e posteriormente passaram por etapas de desnaturação e incubação de aproximadamente $5 \mathrm{~h}$ para a conversão do DNA. As etapas de purificação seguiram como descritas para as análises em oócitos e embriões bovinos (item 3.1.2.2.).

Os primers para amplificação da KvDMR1 e H19DMR bovina foram descritos no item 3.1.2.2. Para amplificação das DMRs de humanos os primers utilizados foram: KvDMR1 FW 5'-GTATTTAGTTAATTYGTGTAGTAGTT-3' e $R v$ 5'-CAAAATCTTACTAAAAAACTCCCTA3'; H19DMR FW 5'-TATGGGTATTTTTGGAGGTTTTTT-3' e Rv 5'- 
AATCCCAAACCATAACACTAAAAC-3'. O primer para a amplificação da H19DMR foi proveniente de estudos realizados por Kim et. al. (2007). Os fragmentos amplificados evidenciando a ilha CpG para a KvDMR1(186pb) e H19DMR (311pb) estão apresentados na figura 10 e 11, respectivamente.

a

gtgcctcatgcggcgctggacccgctgggccaatctgagcccgggtggcatcaaaacgagactctttcg gccaatgacaggacacggcacatcactttccgcacccagccaatccgtgcagcagccCGcCGcaagcct tcccct gct gcCGCCCaat cagcaggtgggggg CGgt CGCCaCGt CGgcagCGgCGggggcagt CGgag CGctgcCGcagtctccaggcagaaCGgt CGCCGCGt CGcctcagcaCGgacctccagggagctcctcag caagatcctgccagggcgeccetcagcgcgattctgccggggtgcctctcagcgtggtcctccccgggg ctcctcagcacgattctccogtgcgeccetcagcgcggtc

b

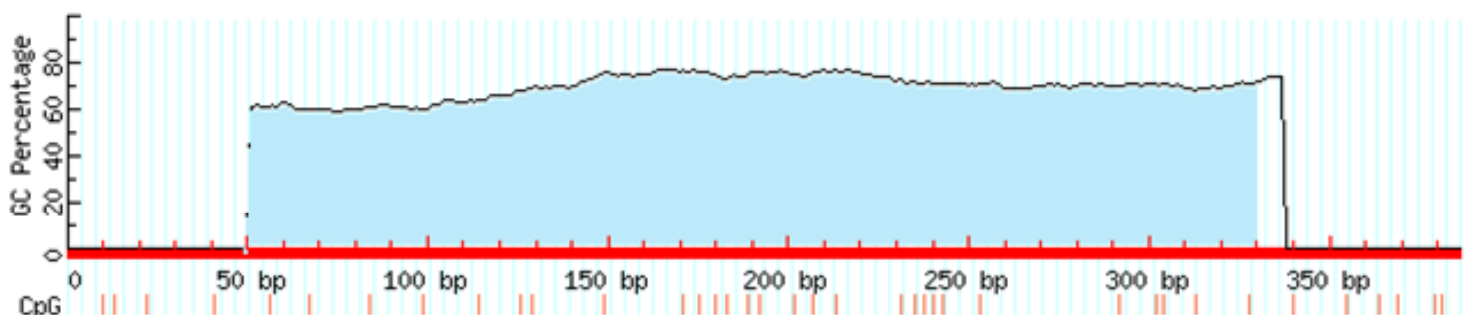

Figura 10: a) Seqüência genômica da KvDMR1 de Humano. Em azul: os dinucleotídeos CpGs analisados (18); Em vermelho: as regiões de pareamento dos primers utilizados. b) Gráfico gerado pelo programa MethPrimer (Li e Dahiya, 2002) evidenciando a Ilha CpG (em azul) em fragmento correspondente a KvDMR1.

a

ggtgtcccagttccatggatgatggggatctcggccctagtgtgaaacccttctcgcagggtctctggc aggcacagagcccgggggctcttgcatagcacatgggtatttctggaggcttctccttcggtctcaccg cctggatggcacggaattggttgtagttgtggaatcggaagtggcCGCGCGgCGgcagtgcaggctcac

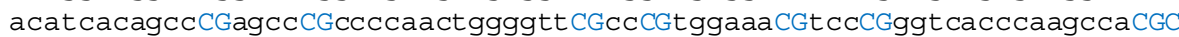
GtCGcagggttcaCGggggtcatctgggaataggacactcataggagcCGcaccagatcttcaggtCGg gcattatccacagcccCGtggcccCGggtcacactcCGagggcttcagtgtcatggcctgggactcaag tcacgcctacttatgtgatgatcacagtgtgttccaccaaaatcttacattttccacatctatcccaga gcacagctccgactccgtctaaggacag

b

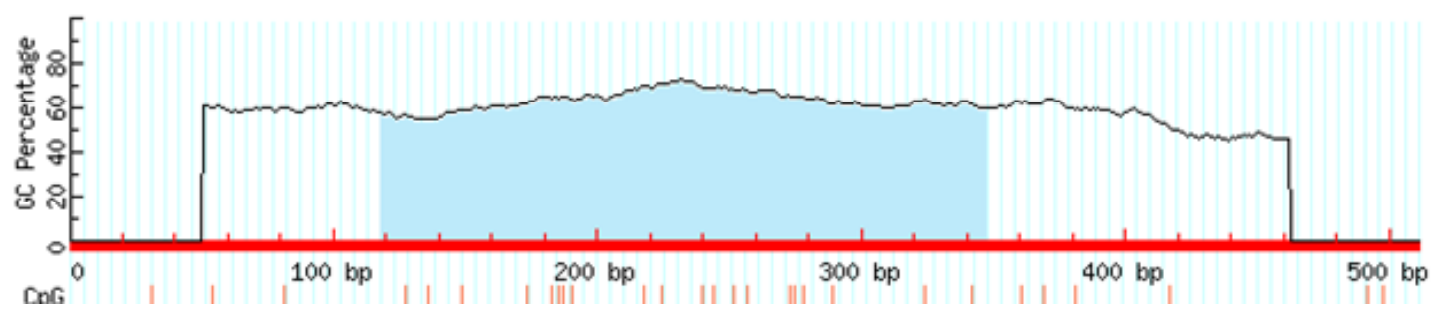

Figura 11: a) Seqüência genômica da H19DMR de Humano. Em azul: os dinucleotídeos CpGs analisados (18); Em vermelho: as regiões de pareamento dos primers utilizados. b) Gráfico gerado pelo programa MethPrimer (Li e Dahiya, 2002) evidenciando a llha CpG (em azul) em fragmento correspondente a H19DMR. 
A amplificação do DNA modificado foi realizada com enzima Hot Start nas mesmas condições para as DMRs humana e bovina, sendo que as reações de amplificação foram realizadas em um volume final de $25 \mu \mathrm{l}$, contendo $1 \mathrm{X}$ GeneAmp PCR Buffer $(500 \mathrm{mM} \mathrm{KCl}$; $100 \mathrm{mM}$ Tris $\mathrm{HCl}$ ( $\mathrm{pH} 8,3) ; 15 \mathrm{mM} \mathrm{MgCl}$ ) (Applied Biosystems); dNTP (0,1 mM de cada nucleotídeo); primer 0,5 pmol (de cada); $1 U$ de AmplitaqTaq ${ }^{\circledR}$ Gold DNA Polimerase (Applied Biosystems) e 1-2 $\mu \mathrm{l}$ de DNA modificado. As ciclagens de temperatura seguiram um aquecimento inicial à $95^{\circ} \mathrm{C}$ por 5 minutos e 50 ciclos de desnaturação à $94^{\circ} \mathrm{C}$ por 45 segundos, pareamento à $58^{\circ} \mathrm{C}$ por 45 segundos, extensão à $72^{\circ} \mathrm{C}$ por 45 segundos e, posteriormente, uma extensão final de $72^{\circ} \mathrm{C}$ por 10 minutos. Os produtos de amplificação foram visualizados em gel de agarose $(2,5 \%)$ corado com brometo de etídeo. A clonagem e o seqüenciamento e as análises de metilação, foram realizados como descrito para as análises em embriões e oócitos bovinos descritas nos itens 3.1.2.3 e 3.1 .2 .3 respectivamente. 
RESULTADOS 


\section{RESULTADOS}

\subsection{PADRÃO DE METILAÇÃO DA KvDMR1 E H19DMR E EXPRESSÃO GÊNICA DIFERENCIAL EM OÓCITOS E EMBRIÕES PRÉ-IMPLANTAÇÃO BOVINOS}

\subsubsection{Produção de embriões in vitro,}

Os resultados apresentados para a coleta dos oócitos e para a produção dos embriões pré-implantação foram realizados no LMEM. A coleta dos oócitos $\mathrm{Vg}$ e MII foi realizada após a remoção das células do cumulus onde pode ser observado na figura 12 (a e b) que o protocolo utilizado foi eficiente para a completa retirada dessas células do gameta feminino. O detalhe da seta na figura 12 mostra a possível formação do primeiro corpúsculo polar após o final da primeira divisão meiótica

a

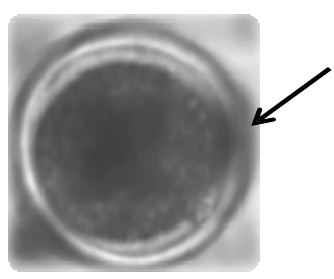

b

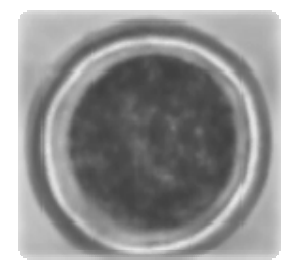

Figura 12: Oócitos MII (a e b) após a remoção das células do cumulus (aumento de 100X). Seta: formação do primeiro corpúsculo polar.

Para a produção dos embriões in vitro, os COCs maturados foram inseminados com o sêmen do mesmo touro, selecionado por apresentar uma alta concentração de espermatozóides no líquido seminal e uma alta motilidade espermática, obtendo-se uma alta taxa de oócitos inseminados chegando ao estágio de blastocisto.

No final dos sete dias de CIV, os embriões encontravam-se no estágio de blastocisto, o qual foi selecionado para os estudos de metilação por ser a fase mais avançada do desenvolvimento embrionário, passando por todas as etapas da PIV.

Os blastocistos viáveis presentes no final do CIV foram classificados em quatro fases de desenvolvimento, com base em suas características morfológicas, as quais podem ser observadas na figura 13. A primeira fase é denominada blastocisto inicial (Bi) onde ocorre o início da formação da blastocele (cavidade) que ocupa menos da metade do volume do embrião. A segunda fase de desenvolvimento é o blastocisto propriamente dito (BI): onde a cavidade já ocupa a metade ou mais do volume total do embrião, com o inicio da formação do botão embrionário. Em seguida ocorre a expansão da blastocele, a redução do botão 
embrionário e a zona pelúcida do embrião apresenta-se delgada no estágio correspondente ao blastocisto expandido ( $\mathrm{Bx})$. Finalmente, no estágio de blastocisto eclodido $(\mathrm{Be})$ é observada a ruptura da zona pelúcida e ocorre o processo de eclosão embrionária.

a

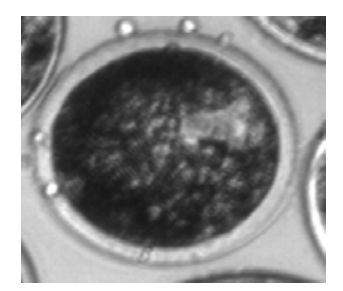

b

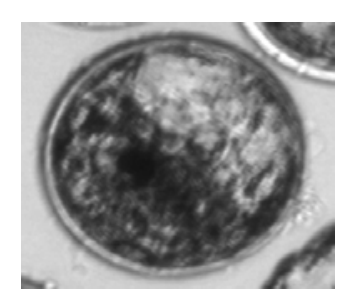

C

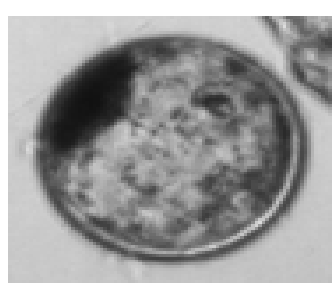

d

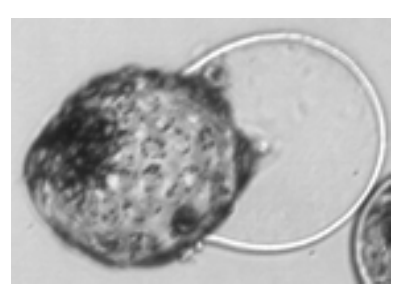

Figura 13: Morfologia do blastocisto durante o desenvolvimento embrionário pré-implantacional (aumento de 100X). a) Blastocisto inicial; b) Blastocisto; c) Blastocisto expandido; d - Blastocisto eclodido (Banco de imagem do LMEM)

Dentre os estágios de desenvolvimento dos blastocistos, foram selecionadas duas fases distintas de acordo com suas características morfológicas e por estarem presentes em maior quantidade na placa de cultivo, sendo uma mais precoce, o $\mathrm{Bi}$, que apresenta em torno de 40 a 60 células e, uma fase mais avançada, o Bx, contendo cerca de 180 a 550 células (Antunes et al., 2008). Um número variado de grupos de oócitos e blastocistos foi testado, sendo que os melhores resultados foram obtidos com grupos de 25. Com essas amostras foi possível estabelecer um protocolo para a modificação do DNA em amostras contendo pouca quantidade de material inicial.

\subsubsection{Amplificação e clonagem da KvDMR1 e H19DMR}

O DNA extraído foi utilizado para a modificação com bissulfito de sódio e os resultados das amplificações da região KvMDR1 estão apresentados na figura 14.

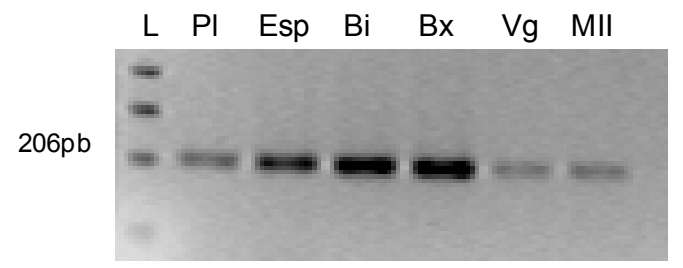

Figura 14: Amplificação da região KvDMR1 em gel de agarose (2,5\%) corado com brometo de etídio. L: Marcador de 100pb; PI: placenta, controle positivo de amplificação; Esp: espermatozóide; Bi: blastocisto inicial; Bx: blastocisto expandido; Vg: vesícula germinativa; MII: oócito MII. 
A amplificação da H19DMR está apresentada na figura 15. O padrão de bandas apresentou-se fraco quando comparado com a amplificação da KvDMR1 para as amostras de placenta, espermatozóide e para os blastocistos Bi e Bx. Para as amostras Vg e MII não foi possível observar banda no gel, no entanto, uma tentativa de clonagem foi realizada uma vez que esta técnica é altamente sensível.

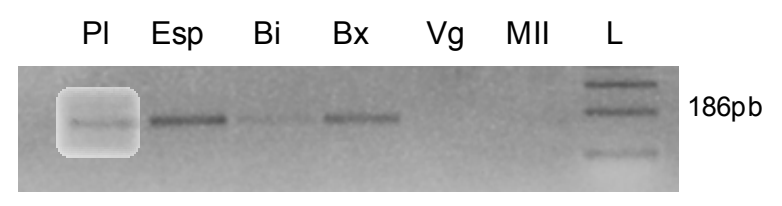

Figura 15: Amplificação da região H19DMR em gel de agarose $(2,5 \%)$ corado com brometo de etídio. L: Marcador de 100pb; PI: placenta, controle positivo de amplificação; Esp: espermatozóide; Bi: blastocisto inicial; Bx: blastocisto expandido; Vg: vesícula germinativa; MII: oócito MII.

Os fragmentos resultantes da amplificação da KVDMR1 e H19DMR foram diretamente clonados e de maneira geral, a eficiência de clonagem foi relativamente alta, com um grande número de colônias nas placas. As amostras que não apresentaram bandas na amplificação (oócito Vg e MII para a H19DMR), tinham uma menor proporção de clones positivos nas placas, porém foi possível selecionar um número suficiente para o seqüenciamento com padrão de bandas semelhante às demais amostras.

\subsubsection{Seqüenciamento de bissulfito}

Após a seleção dos clones positivos, cerca de seis a 12 amostras de cada região foram enviadas para o seqüenciamento automático de nucleotídeos. De acordo com os resultados obtidos a partir do seqüenciamento, foi possível observar que a modificação do DNA foi satisfatória, apresentando cerca de 90 a 100\% de conversão das citosinas não CpG em timinas e uma alta identidade entre as sequências (85 a 100\%).

Na figura 16 estão apresentados os resultados de alinhamento das regiões KvDMR1 e H19DMR para a amostra de DNA extraído de espermatozóide que foi utilizada como controle de modificação. 
a

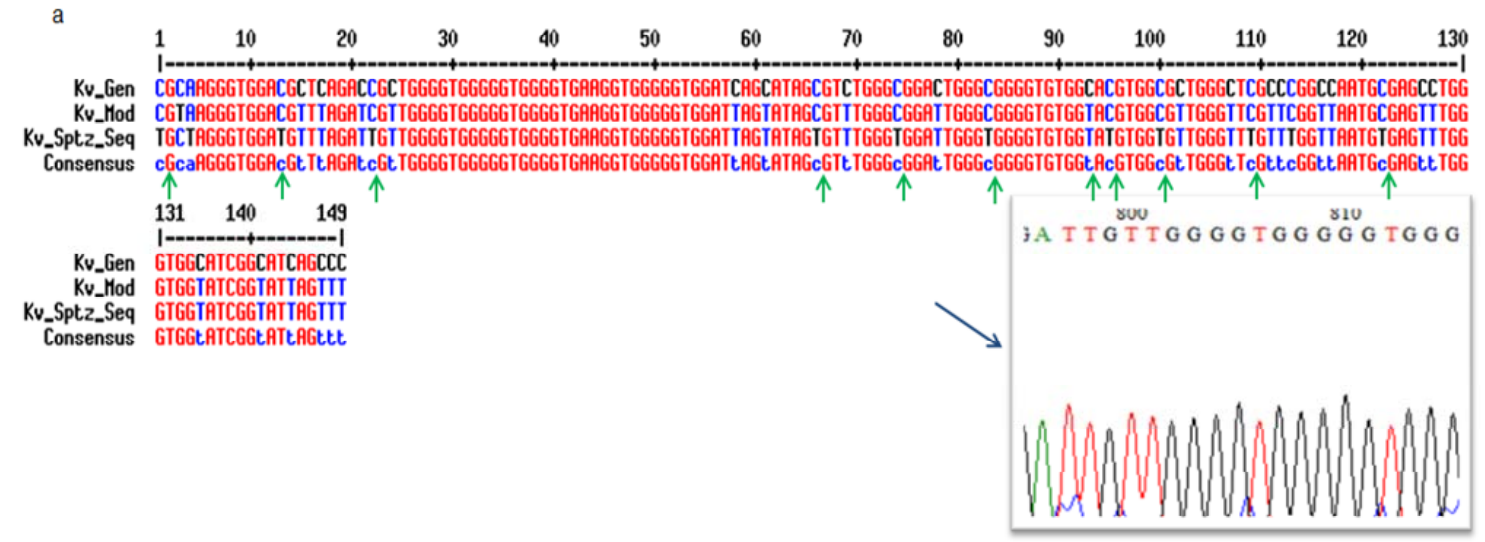

b

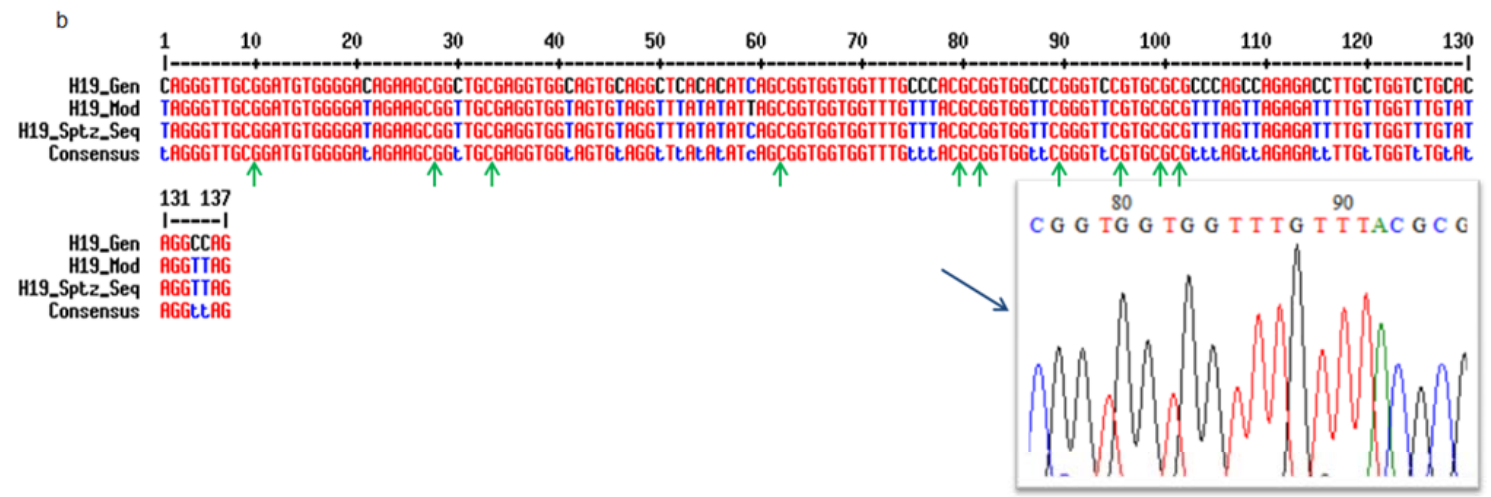

Figura 16: Alinhamento da sequência gerada a partir do seqüenciamento de nucleotídeos após a modificação do DNA com bissulfito com as sequências genômica e modificada. a) Alinhamento da KvDMR1 em amostra de DNA extraído de espermatozóide. b) Alinhamento da H19DMR em amostra de DNA extraído de espermatozóide. Seta verde: sítios CGs:. Seta azul: eletroferogramas das sequências alinhadas. Gráfico gerado pelo programa Mult Alin (Corpet, 1988)

O fragmento analisado correspondente à KvDMR1 bovina cobriu 18 sítios CGs os quais, em sua maioria, foram convertidos em TG na amostra de DNA extraído de espermatozóide apresentando um padrão hipometilado para esta região com 7,5\% (8/107) de metilação (Figura 17a). O fragmento correspondente à H19DMR não está localizado dentro de uma ilha $\mathrm{CpG}$, no entanto corresponde a uma região diferencialmente metilada onde provavelmente localiza-se o sítio 6 de ligação a proteína CTCF (Rios, 2007). Dentro dessa região foram analisados 10 sítios CGs para cada amostra, os quais apresentaram um padrão hipermetilado para o espermatozóide, contendo 98\% (56/60) de metilação nos pontos analisados (Figura 17b).

a

$$
\text { KvDMR - Esp (7,5\%) }
$$

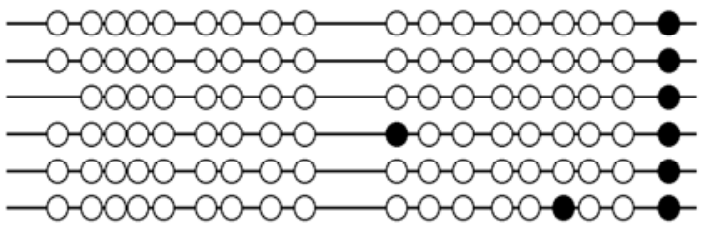

b

$$
\text { H19DMR - Esp (98\%) }
$$

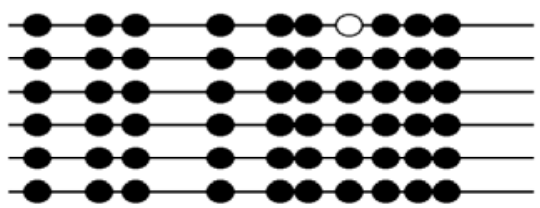

Figura 17: Padrão de metilação das regiões KvDMR1 e H19DMR em espermatozóide (Esp). a) Hipometilação da KvDMR1. b) Hipermetilação da H19DMR. Círculos abertos: sítios não metilados. Círculos fechados: sítios metilados. 


\subsubsection{Padrão de metilação da região KvDMR1}

A KvDMR1 é preferencialmente metilada no alelo materno. A análise do padrão de metilação dessa região nos oócitos $\mathrm{Vg}$ mostrou um perfil hipermetilado com $88,8 \%$ (143/161) de metilação (Figura 18a). No entanto, para as amostras de oócitos MII, houve uma perda de metilação após a maturação, quando comparados com os oócitos $\mathrm{Vg}$, em que a porcentagem de metilação correspondeu a 43,1\% (62/144) (Figura 18b). O nível de metilação entre cada pondo individualmente variou, conforme pode ser observado na figura 18c, em especial para os oócitos Vg, visto que a maioria dos pontos nos oócitos MIl está metilado. Somente um ponto (18, posição 198) não apresentou diferença de metilação entre os oócitos Vg e MII o qual está hipermetilado em todos os clones. Na amostra controle de espermatozóide, a qual apresentou hipometilação da KvDMR1 o ponto 18 encontra-se totalmente metilado em todos os clones analisados independentemente do seu estado de metilação.

a

$\operatorname{Vg}(88,8 \%)$

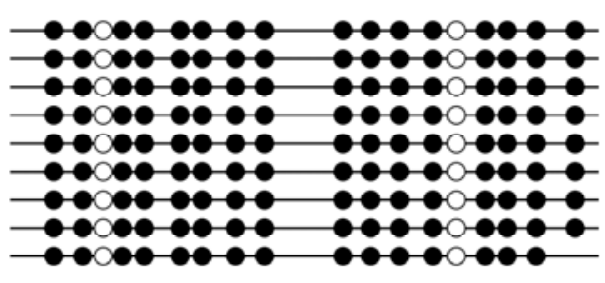

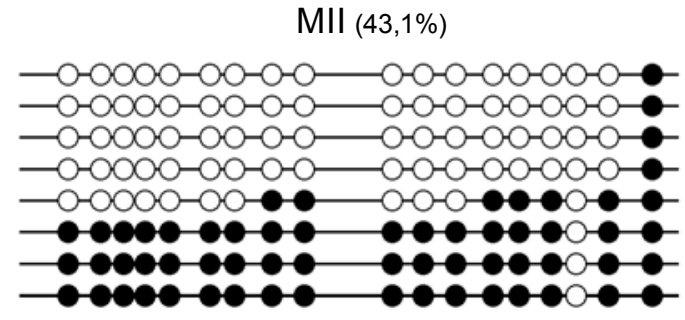

C

Sítios CG

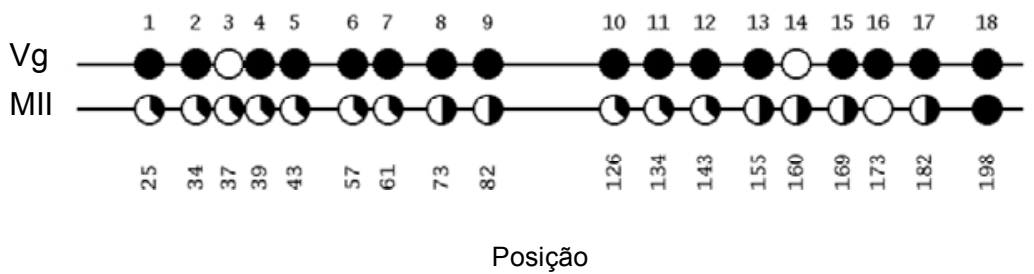

Figura 18: Padrão de metilação da KvDMR1. a) Vesícula germinativa (Vg). b) Oócitos MII (MII). c) Nível de metilação de cada sítio CG. Círculos abertos: sítios não metilados. Círculos fechados: sítios metilados. Círculos parcialmente fechados ou abertos: nível de metilação em cada ponto. Números abaixo da figura: posição do sítio CG na sequência analisada. Números acima da figura: referente ao sítio CG analisado.

Para as amostras dos embriões pré-implantação no estágio de blastocisto inicial e blastocisto expandido, após sete dias de cultivo in vitro foi observada uma tendência à perda de metilação com o avanço das sucessivas divisões e do crescimento embrionário (figura 19). No estágio mais precoce $(\mathrm{Bi})$ a porcentagem de metilação da KvDMR1 foi de $80,2 \%$ 
(130/162) sugerindo um perfil hipermetilado. Por outro lado, no estágio mais avançado de desenvolvimento que corresponde aos $\mathrm{Bx}$, a porcentagem de metilação foi de $26,4 \%$ (47/178), resultado que sugere um estado de hipometilação dessa região no final do desenvolvimento embrionário pré-implantacional. Quando comparada as duas amostras, o nível de metilação entre cada ponto CG foi variado, apresentando metilação diferencial entre eles (figura 19c), sendo que o ponto 18 (posição 198) novamente encontra-se metilado nos $\mathrm{Bi}$ e Bx, conforme padrão encontrado para as amostras de oócitos.

a

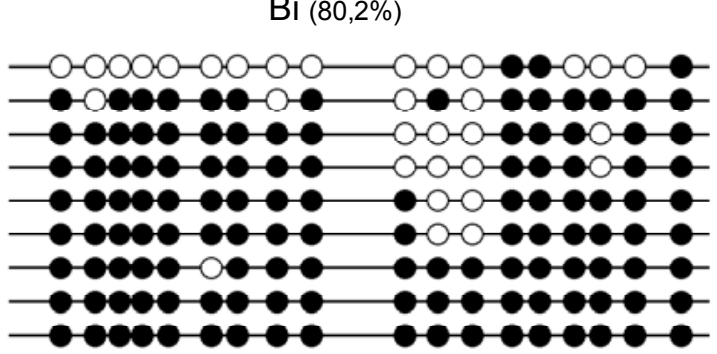
Bx $(26,4 \%)$

C Sítios CG

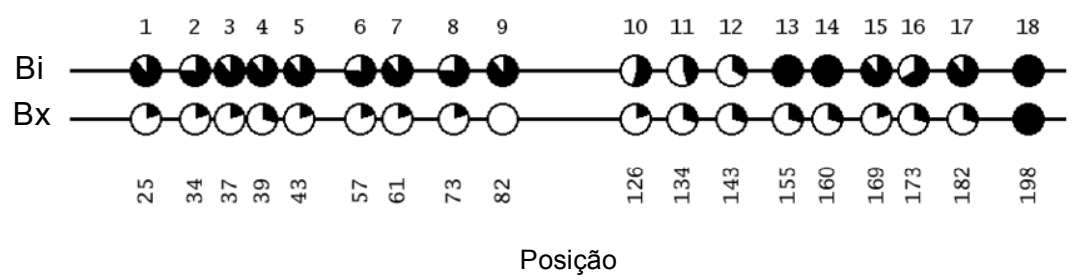

Figura 19: Padrão de metilação KvDMR1. a) Blastocisto inicial (Bi). b) Blastocisto expandido (Bx). c) Nivel de metilação de cada sítio CG. Círculos abertos: sítios não metilados. Círculos fechados: sítios metilados. Círculos parcialmente fechados ou abertos: nível de metilação em cada ponto. Números abaixo da figura: posição do sítio CG na sequência analisada. Números acima da figura: referente ao sítio CG analisado.

\subsubsection{Padrão de metilação da H19DMR}

A metilação da H19DMR ocorre preferencialmente no alelo paterno, no entanto os resultados encontrados para as amostras dos oócitos $\mathrm{Vg}$ e MII, antes e após a maturação respectivamente, mostraram um perfil hipermetilado para esta região nas duas amostras analisadas conforme observado na figura 20. A porcentagem de metilação foi de $80 \%$ (72/90) para o oócito $\mathrm{Vg}$ e 82,5\% (99/120) para o oócito MII. O nível de metilação entre todos os pontos CG não variou, os quais estão metilados em sua maioria. Somente o ponto 7 (posição 88) está praticamente demetilado para todas as amostras, apresentando $5 \%$ de metilação nos oócitos $\mathrm{Vg}$. 
a

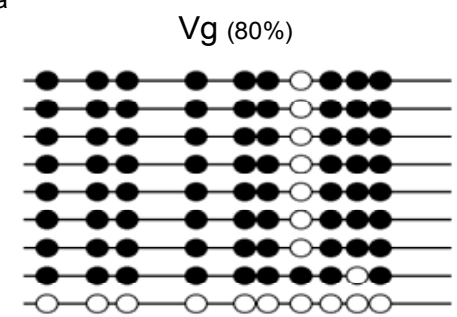

b

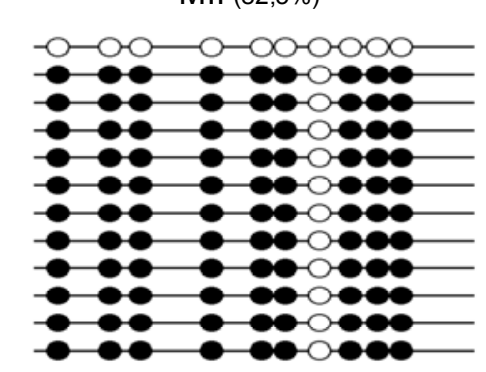

c

Sítios CG

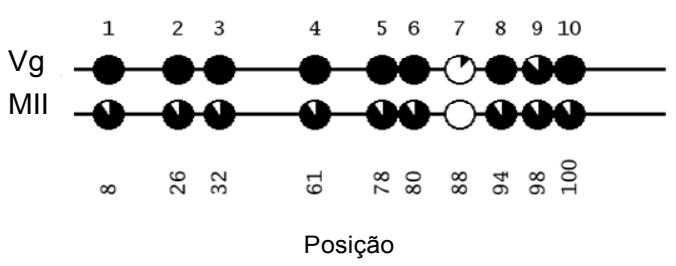

Figura 20: Padrão de metilação da H19DMR. a) Vesícula germinativa (Vg). b) Oócitos MII (MII). c) Nivel de metilação de cada sítio CG. Círculos abertos: sítios não metilados. Círculos fechados: sítios metilados. Círculos parcialmente fechados ou abertos: nível de metilação em cada ponto. Números abaixo da figura: posição do sítio CG na sequência analisada. Números acima da figura: referente ao sítio CG analisado.

Para os embriões pré-implantação Bi e Bx, o perfil de metilação da H19DMR mostrou uma característica de ganho de metilação com o avanço do desenvolvimento embrionário in vitro (figura 21). Nos Bi o perfil de metilação da H19DMR apresentou-se hipometilado, contendo 10,1\% (13/129) de metilação nos sítios CG analisados. Com o crescimento do embrião, nos Bx, é observado um perfil correspondente a um estado diferencialmente metilado contendo $54,5 \%$ (60/110) de metilação nos clones analisados. A análise entre os pontos dessa região mostrou que todos os CGs apresentaram diferentes níveis de metilação nos Bi e Bx.

a

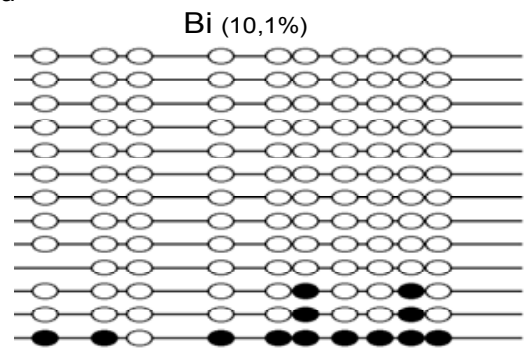

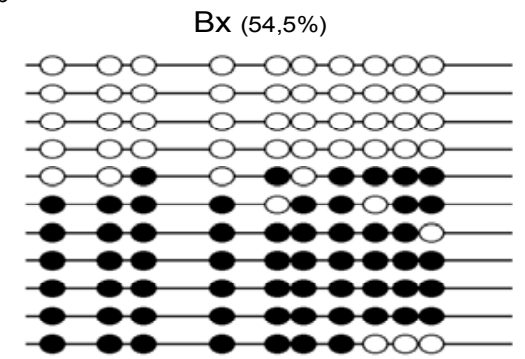

c

Sítios CG

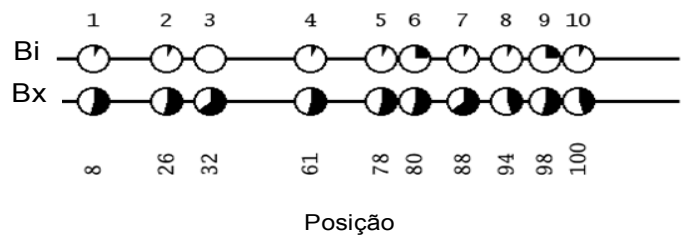

Figura 21: Padrão de metilação H19DMR. a) Blastocisto inicial (Bi). b) Blastocisto expandido (Bx). c) Nivel de metilação de cada sítio CG. Círculos abertos: sítios não metilados. Círculos fechados: sítios metilados. Círculos parcialmente fechados ou abertos: nível de metilação em cada ponto. Números abaixo da figura: posição do sítio CG na sequência analisada. Números acima da figura: referente ao sítio CG analisado. 


\subsubsection{Análise da Expressão Gênica}

As análises de expressão dos genes LIT1 e IGF2 foram realizadas para os oócitos $\mathrm{Vg}$ e Mll e blastocistos $\mathrm{Bi}$ e Bx. Para todas as amostras, foi realizada uma quantificação em tempo real das RT-negativas. Os resultados confirmaram a ausência de contaminação por DNA genômico, em que não houve amplificação do GAPDH durante a qPCR.

Para as amostras de Vg e MII não houve variação do perfil de amplificação entre os genes $\beta$-actina e GAPDH. No entanto, para os blastocistos houve uma diferença de aproximadamente três ciclos entre os dois genes referência. Os resultados das médias dos Cqs entre as triplicatas amostrais para cada gene referência estão apresentados na tabela 2.

Tabela 2: Ciclo de quantificação $(\mathrm{Cq})$ médio entre as triplicatas amostrais para os genes $\beta$ actina e GAPDH.

\begin{tabular}{l|c|c}
\hline \hline Amostra* & $\beta$-actina & GAPDH \\
\hline \hline $\mathrm{Vg}$ & 26,95 & 26,24 \\
$\mathrm{MII}$ & 25,94 & 25,62 \\
$\mathrm{Bi}$ & 25,67 & 28,86 \\
$\mathrm{Bx}$ & 25,93 & 29,12 \\
\hline
\end{tabular}

* Vg: vesícula germinativa. MII: oócito MII. Bi: blastocisto inicial. Bx: blastocisto expandido

A quantificação relativa (ou $R Q$, do inglês, Relative Quantification) foi realizada com base nos valores de Cq médio de cada gene, utilizando como referência somente o gene $\beta$ actina e como normalizador a amostra de células do cumulus para os cálculos de $2^{-\Delta \Delta C q}$. Os valores de RQ para cada gene analisado estão apresentados na tabela 3. 
Tabela 3: Valores de RQ observados nas reações de PCR em tempo real para os genes em estudo.

\begin{tabular}{|c|c|c|c|c|}
\hline \multirow[b]{2}{*}{ Amostras* } & \multicolumn{2}{|c|}{ LIT1 } & \multicolumn{2}{|c|}{ IGF2 } \\
\hline & $\mathbf{R Q}^{1}\left(\mathrm{DP}^{2}\right)$ & Média & $\mathrm{RQ}^{1}\left(\mathrm{DP}^{2}\right)$ & Média \\
\hline$\overline{V g}(1)$ & $0,94(0,30)$ & $0,60(0,16)$ & $0,84(0,07)$ & $0,75(0,08)$ \\
\hline $\operatorname{Vg}(3)$ & $0,27(0,02)$ & & $0,66(0,09)$ & \\
\hline MII (1) & $0,23(0,12)$ & $0,22(0,09)$ & $3,78(0,07)$ & $4,67(0,82)$ \\
\hline MII (2) & $0,24(0,09)$ & & $4,13(1,27)$ & \\
\hline MII (3) & $0,18(0,06)$ & & $6,11(1,13)$ & \\
\hline $\mathrm{Bi}(1)$ & $0,90(0,55)$ & $0,55(0,26)$ & 0,0 & 0,0 \\
\hline $\mathrm{Bi}(2)$ & $0,42(0,16)$ & & 0,0 & \\
\hline $\mathrm{Bi}(3)$ & $0,32(0,06)$ & & 0,0 & \\
\hline $\mathrm{Bx}(1)$ & $0,49(0,01)$ & $0,92(0,38)$ & 0,0 & 0,0 \\
\hline $\mathrm{Bx}(2)$ & $0,76(0,84)$ & & 0,0 & \\
\hline $\mathrm{Bx}(3)$ & $1,51(0,28)$ & & 0,0 & \\
\hline
\end{tabular}

* Vg: vesícula germinativa. MII: oócito MIl. Bi: blastocisto inicial. Bx: blastocisto expandido. ${ }^{1} \mathrm{RQ}$ : quantificação relativa. ${ }^{2} \mathrm{DP}$ : desvio padrão

De acordo com os valores de $R Q$ foi observado que os genes analisados apresentaram baixos níveis de expressão para todas as amostras com o Cq médio variando entre 36,07 a 38,14 para o gene LIT1 e 34,22 e 37,75 para o gene IGF2.

Apesar dos baixos níveis de expressão dos genes analisados, nas amostras de $\mathrm{Vg}$ foi observado um que houve um valor médio de expressão maior para o gene IGF2 $(0,75)$ quando comparado com o gene LIT1 $(0,6)$. Para as amostras dos oócitos MII as diferenças de expressão entre os genes IGF2 e LIT1 foi maior nessas amostras, em que o gene LIT1 apresentou um valor de $R Q$ médio entre as triplicatas de 0,22 , enquanto que para o IGF2 o $R Q$ foi entre 4,67 (Figura 22).

A expressão relativa para os genes estudados apresentou semelhantes resultados para os blastocistos $\mathrm{Bi}$ e $\mathrm{Bx}$, onde foi observada somente expressão do gene LIT1 em baixos níveis, como nos oócitos, não sendo detectada expressão do IGF2 nessas amostras. (Figura 22). 


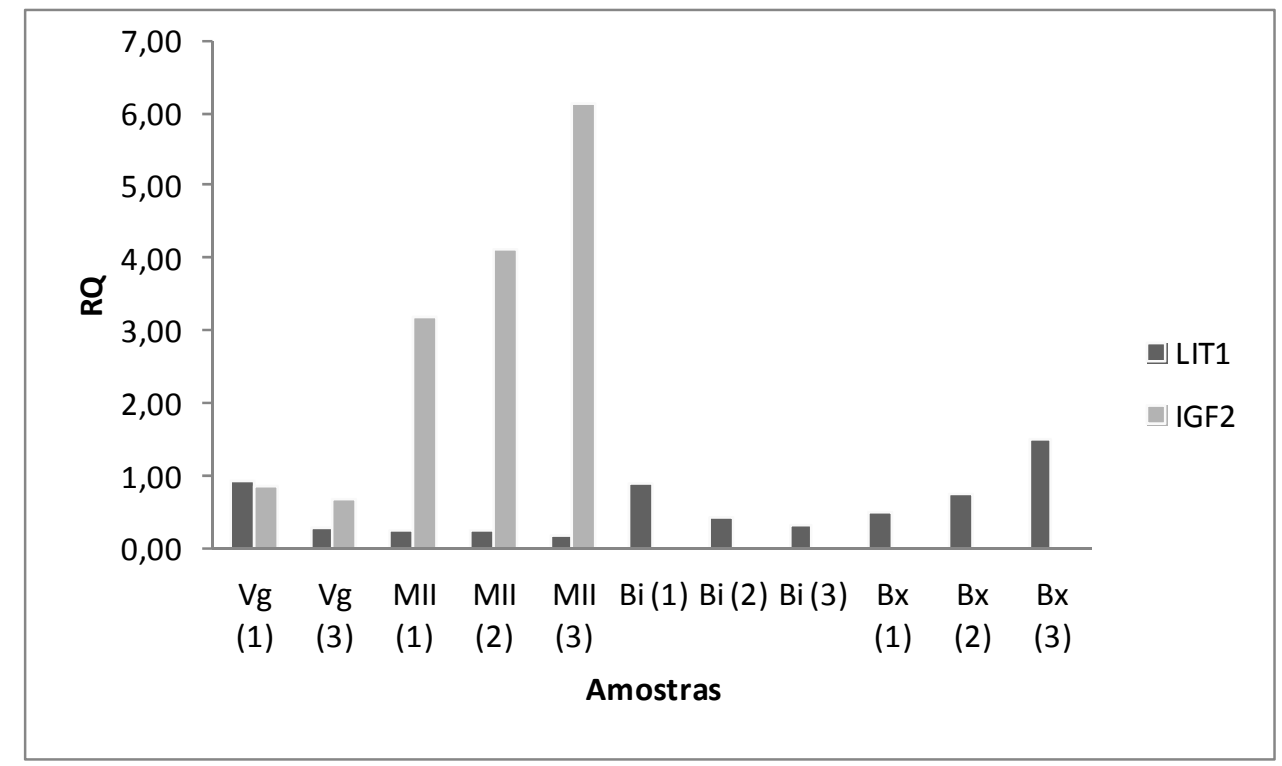

Figura 22: Expressão relativa dos genes LIT1 e IGF2 para as amostras analisadas. Vg: vesícula germinativa. MII: oócito MII. Bi: blastocisto inicial. Bx: blastocisto expandido

Os genes LIT1 e IGF2 apresentaram níveis diferentes de expressão entre as amostras de oócitos e blastocistos. Os maiores níveis de expressão do gene IGF2 foram encontrados nas amostras dos oócitos $\mathrm{Vg}$ e $\mathrm{MII}$, sendo que essas últimas apresentaram diferenças consideráveis de expressão desse gene. Nos Bi e Bx, foi detectada unicamente a expressão do gene LIT1, o qual foi expresso em níveis semelhantes nas duas amostras, e não foi detectada a expressão do gene IGF2.

\subsubsection{Resumo dos resultados}

Os resultados de metilação e expressão das amostras de oócitos e blastocistos foram agrupados na tabela 4 para melhor compreensão dos mesmos.

Tabela 4: Resultados agrupados das análises de metilação e expressão.

\begin{tabular}{ccccc}
\hline \hline \multirow{2}{*}{ Amostra* $^{*}$} & \multicolumn{2}{c}{ \% Metilação (Densidade) } & \multicolumn{2}{c}{ Expressão } \\
\cline { 2 - 5 } & KvDMR1 & H19DMR & LIT1 & IGF2 \\
\hline \hline Esp & $7,5(8 / 107)$ & $98(56 / 60)$ & ------- & ------- \\
Vg & $88(143 / 161)$ & $80(72 / 90)$ & 0,60 & 0,75 \\
$\mathrm{MII}$ & $43,1(62 / 144)$ & $82,5(99 / 120)$ & 0,22 & 4,47 \\
$\mathrm{Bi}$ & $80,2(130 / 162)$ & $10,1(13 / 129)$ & 0,55 & 0,0 \\
$\mathrm{Bx}$ & $26,4(47 / 178)$ & $54,5(60 / 110)$ & 0,92 & 0,0 \\
\hline
\end{tabular}

* Esp: espermatozóide. Vg: vesícula germinativa. MIl: oócito MII. Bi: blastocisto inicial. Bx: blastocisto expandido 


\subsection{ANÁLISE COMPARATIVA DO PADRÃO DE METILAÇÃO DAS KvDMR1 E H19DMR EM PLACENTAS PRECOCES BOVINA E HUMANA}

\subsubsection{Análise de metilação em bovinos}

A sexagem das amostras do embrião e dos cotilédones (Co) de $49 \mathrm{~d}$ de idade gestacional mostraram que as amostras eram provenientes de uma gestação de um feto masculino.

Após a sexagem as amostras foram modificadas e a KvDMR1 e H19DMR foram amplificadas conforme padrão de bandas apresentado nas amostras de oócitos e blastocistos (Figura 14). Os produtos de PCR foram clonados e após a seleção dos clones positivos as amostras foram seqüenciadas e alinhadas com as sequências genômica e modificada da KvDMR1 e H19DMR.

Os resultados do perfil de metilação da KvDMR1 e H19DMR mostraram um funcionamento inverso dessas regiões em uma mesma amostra, enquanto uma apresenta um nível de metilação aumentado, a outra região apresenta um nível reduzido de metilação.

O perfil de metilação do embrião 49d para a KvDMR1 e H19DMR está apresentado na figura 23. Para a KvDMR1 foi observada uma tendência à hipermetilação dessa região, com 72\% (130/180) de metilação nos clones analisados. Diferentemente, para a H19DMR foi observado um perfil hipometilado, cuja porcentagem de metilação foi de $26 \%$ (24/90) de metilação. As análises da variação entre os pontos não podem ser realizadas nessas amostras, visto que o programa somente permite comparações entre duas amostras.

a

KvDMR1 Em (72.2\%)

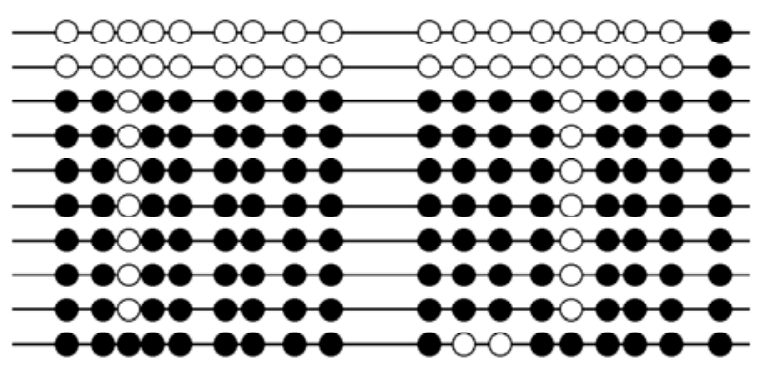

b

H19DMR Em(26.7\%)

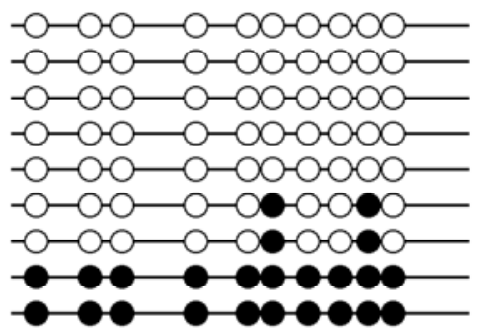

Figura 23: Perfil de metilação do embrião. a) KvDMR1. b) H19DMR. Em: embrião. Círculos abertos: sítios não metilados. Círculos fechados: sítios metilados. 
O nível de metilação dos cotilédones variou entre as amostras conforme observado nas figuras 24 e 25 para as duas regiões analisadas. As amostras que mostraram maiores níveis de metilação para a KvMDR1 foram os Co 1 e Co 3, onde a porcentagem de metilação foi de 88,9\% (160/180) e 91,1\% (164/180), respectivamente. Os Co 2 e Co 4 apresentaram níveis mais reduzidos de metilação, com uma porcentagem de 56,9\% (82/144) e 39,6\% (82/144), respectivamente.

Considerando o ponto 18 de metilação nessas amostras, foi possível observar que o padrão metilado se manteve para as amostras do embrião, bem como para os Co, apresentando $100 \%$ de metilação, semelhante aos resultados encontrados para os oócitos e blastocistos.

Co $1(88.9 \%)$

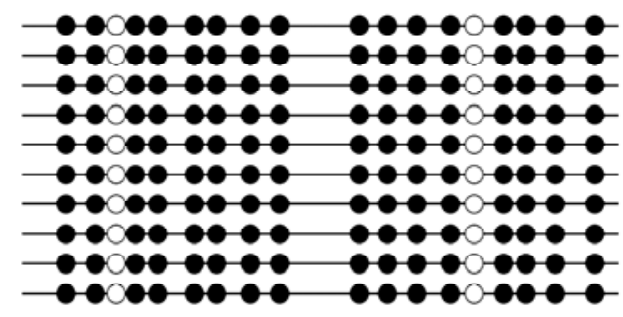

Co $3(91.1 \%)$

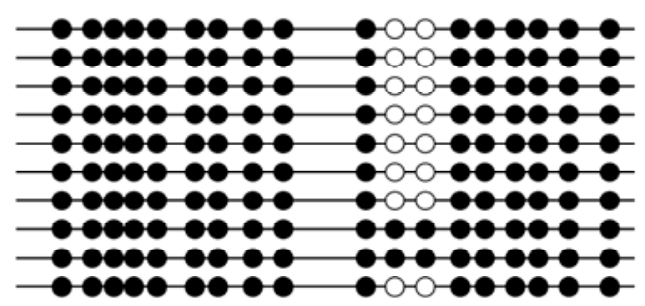

Co $2(56.9 \%)$

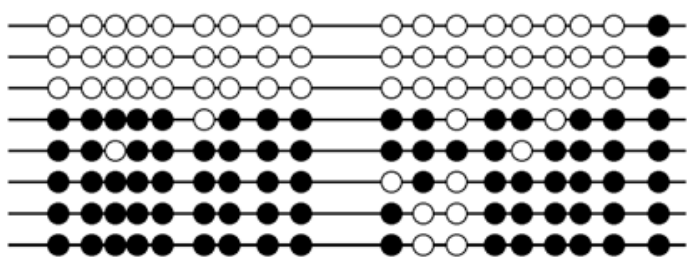

Co $4(39.6 \%)$

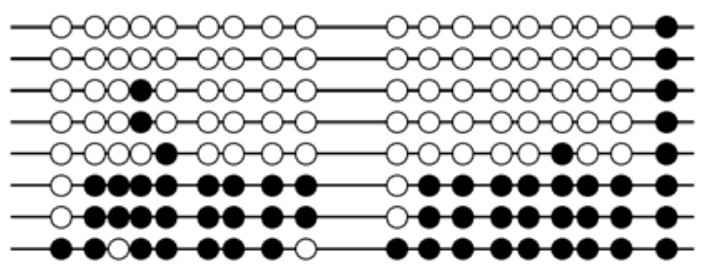

Figura 24: Padrão de metilação KvDMR1. Co: cotilédone. Círculos abertos: sítios não metilados. Círculos fechados: sítios metilados.

A H19DMR apresentou baixos níveis de metilação nos cotilédones que podem ser observados na figura 25 . Os níveis de metilação dessa região variaram entre 35,0\% (21/60) e $57 \%$ (45/79). Somente o Co 2 não apresentou metilação nessa região $(0,0 \%)$. 
Co $1(35.0 \%)$

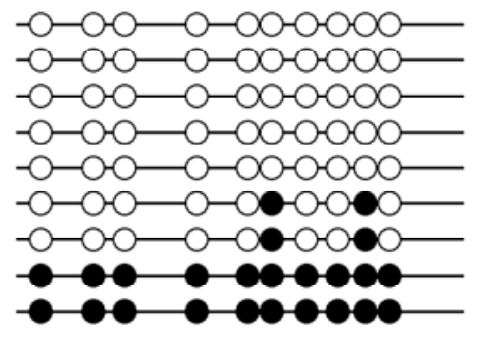

Co $3(46.4 \%)$

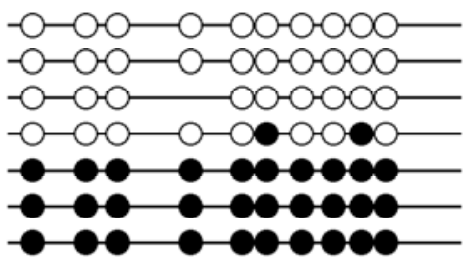

Co $2(0.0 \%)$

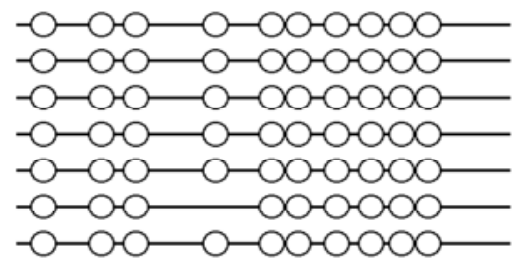

Co $4(57.0 \%)$

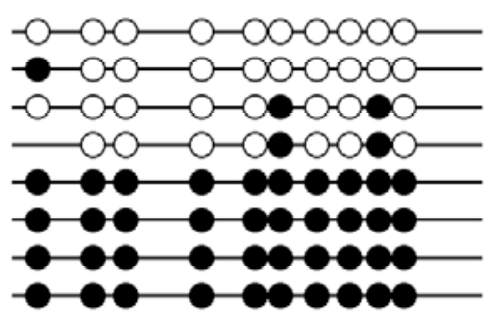

Figura 25: Padrão de metilação da H19DMR. Co: cotilédone. Círculos abertos: sítios não metilados. Círculos fechados: sítios metilados.

\subsubsection{Análise de metilação em humanos.}

As DMRs de humanos foram amplificadas em quatro diferentes vilosidades de uma mesma placenta $(\mathrm{PI})$, e o padrão de bandas dessas regiões podem ser observados na figura 26.

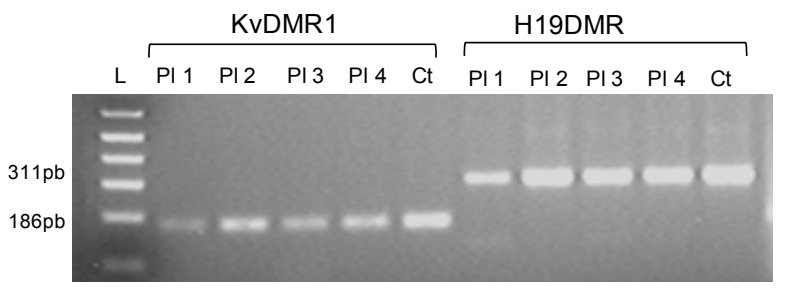

Figura 26: Amplificação da KvDMR1 e H19DMR em gel de agarose (2,5\%) corado com brometo de etídio. L: Marcador de 100pb; PI: placenta; Ct: amostra controle.

Os produtos de PCR foram clonados e os clones positivos foram seqüenciados para todas as amostras. De acordo com os resultados de seqüenciamento, somente a amostra da PI 2 para a H19DMR não foi possível verificar o padrão de metilação.

O padrão de metilação da KvDMR1 nas placentas humanas mostrou uma tendência à hipermetilação em todas as amostras analisadas, com uma variação entre de $93,4 \% \mathrm{e}$ 97,9\% na porcentagem de metilação nas diferentes amostras (Figura 27). 
PI 1 (96,3\%)

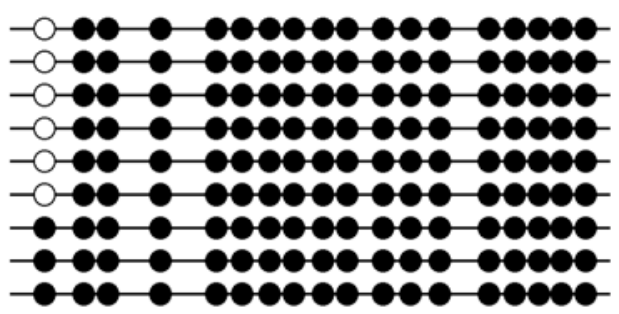

PI 3 (95,8\%)

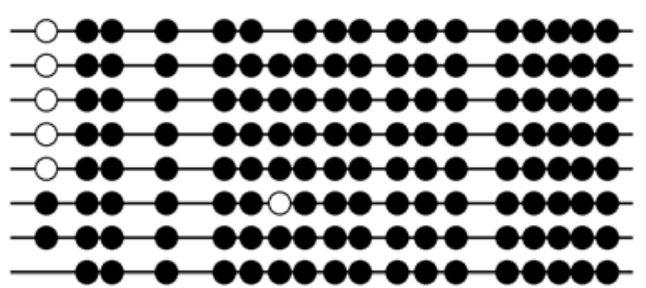

PI 2 (96,3\%)

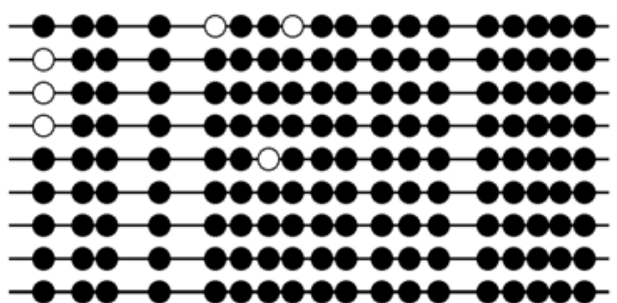

PI 4 (97,9\%)

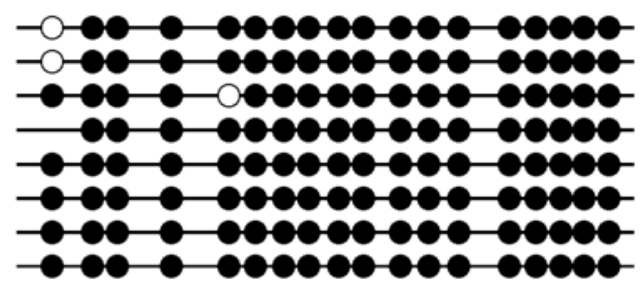

Figura 27: Padrão de metilação da KvDMR1. Co: cotilédone. Círculos abertos: sítios não metilados. Círculos fechados: sítios metilados.

Os resultados para a H19DMR, como para a KvDMR1, mostram um perfil hipermetilado em todas as amostras de placenta analisadas, em que as porcentagens de metilação variaram entre $84,4 \%$ a 95,8\% conforme pode ser observado na Figura 28.

PI 1 (84,4\%)

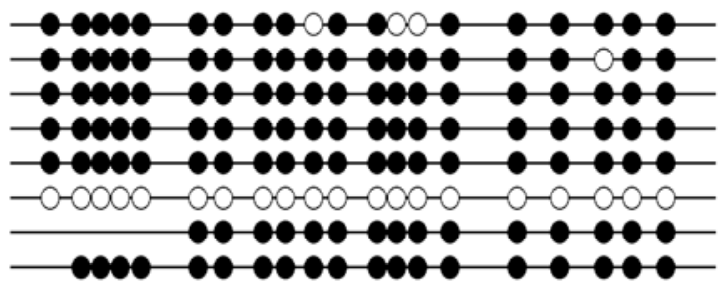

PI 3 (95,8\%)

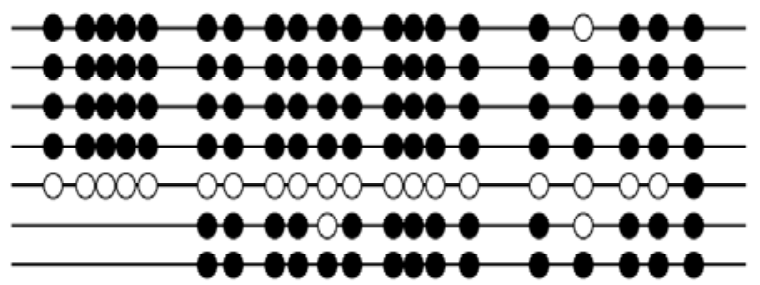

$\mathrm{PI} 4$ (95,8\%)

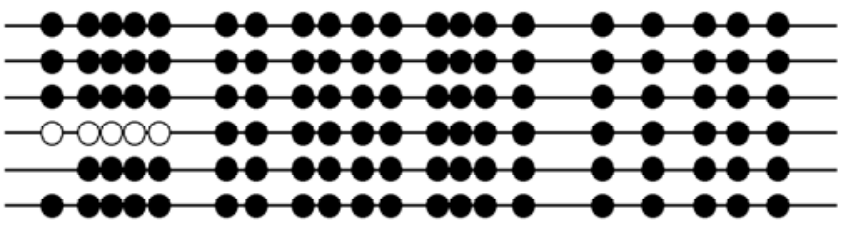

Figura 28: Padrão de metilação KvDMR1. Co: cotilédone. Círculos abertos: sítios não metilados. Círculos fechados: sítios metilados. 


\section{DISCUSSÃO}

\subsection{PADRÃO DE METILAÇÃO DAS REGIÕES KvDMR1 E H19DMR E EXPRESSÃO GENICA DIFERENCIAL EM OÓCITOS E EMBRIÕES PRÉ-IMPLANTAÇÃO BOVINOS}

Crianças concebidas por técnicas de reprodução assistida freqüentemente apresentam erros de imprinting que ocorrem durante o desenvolvimento embrionário. Essas alterações podem ser causadas pelo estresse ambiental no qual os gametas e o embrião estão sujeitos durante os procedimentos relacionados à produção in vitro (Maher, 2005; Paoloni-Giacobino, 2006; Owen e Segars, 2009; lliadou et al., 2011). A maior ligação das alterações de imprinting às TRAs pode estar relacionada ao fato de que a manipulação in vitro ocorre em períodos críticos do desenvolvimento do indivíduo, como na reprogramação epigenética do genoma durante a gametogênese e o inicio do desenvolvimento préimplantacional, impedindo o correto estabelecimento e manutenção da metilação do DNA que ocorre nesses períodos (lliadou et al., 2011)

As DMRs KvDMR1 e H19DMR são altamente vulneráveis à perda de imprtinting (ou LOI, do inglês, Loss of Imprinting) durante os procedimentos de FIV (DeBaun et al., 2003; Lewis e Reik, 2006) e, devido à regulação coordenada que essas ICRs exercem sobre genes importantes relacionado ao crescimento e desenvolvimento, elas tornam-se um foco importante nos estudos do seu estado de metilação em diferentes espécies. Em bovinos essas regiões têm sido pouco estudadas, porém apresentam um crescente interesse devido à sua possível relação com a LOS (Couldrey e Lee, 2010; Hori et al., 2010) e para o estabelecimento de um modelo para estudos em células germinativas e desenvolvimento embrionário em humanos (Hansmann et al., 2010)

Neste trabalho foi verificado o padrão de metilação da KvDMR1 e H19DMR durante diferentes etapas da FIV. Essas análises foram realizadas no oócito sem passar por nenhuma das etapas da FIV, ou seja, logo após a retirada dos folículos no estágio denominado vesícula germinativa. Outro foco deste estudo foi o oócito após o procedimento de MIV e, o embrião pré-implantação no estágio de blastocisto o qual passou por todas as etapas da PIV. De modo geral, as análises de metilação dessas regiões mostraram diferentes perfis de metilação para os blastocistos e um perfil alterado para os oócitos.

A KvDMR1 é metilada preferencialmente no alelo materno em humanos (Horike et al., 2000) e camundongos (Fitzpatrick et al., 2007) e parece apresentar o mesmo padrão em bovinos (Couldrey e Lee, 2010; Hori et al., 2010). Para o estabelecimento do perfil de metilação dessa região nos oócitos e blastocistos, foram analisados 18 sítios CG dentro da ilha CpG correspondente à ICR2 em bovinos. A amostra controle, o espermatozóide, apresenta um perfil completamente demetilado para a KvDMR1, o que foi encontrado neste 
trabalho (Tabela 4 e Figura 17a), já que a metilação para essa região é materna. É interessante ressaltar que o processo de criopreservação do espermatozóide, que é utilizado para conservação do sêmen na PIV, parece não ter alterado o estado de imprinting estabelecido durante a espermatogênese.

As análises de metilação no oócito Vg, logo após a coleta nos folículos ovarianos, mostrou que o padrão de metilação correspondeu ao padrão materno esperado para esta região, em que foi observada uma porcentagem correspondente a $88 \%$ de metilação nos sítios analisados. Diferentemente, no oócito MII, que corresponde ao gameta maduro pronto a ser fertilizado, houve uma perda de metilação $(43,1 \%)$ após a MIV para a KvDMR1. Tendo em vista que a metilação materna ocorre durante o crescimento do oócito, inclusive em bovinos (O'Doherty et al., 2011), a qual parece ser finalizada antes, ou logo após a ovulação, nessas amostras pode ter ocorrido uma falha na aquisição do imprinting dessa região.

A verdadeira influência da MIV no estabelecimento e/ou manutenção do imprinting nos oócitos ainda não está bem elucidada. No entanto, a simples retirada do oócito dos folículos e, em especial, a estimulação hormonal e a cultura in vitro para o crescimento e maturação desse gameta, pode ter alterado o padrão de imprinting dessa DMR (Reik et al., 2001; Manipalviratn et al., 2009).

Geuns et al. (2007) em estudos na KvDMR1 em oócitos humanos em diferentes estágios de desenvolvimento ( $\mathrm{Vg}, \mathrm{Ml}$ e $\mathrm{MII})$ mostrou que a maioria das amostras não apresentou alteração de metilação, onde foi observado completa metilação nos oócitos analisados, destes, uma amostra MI, proveniente de ciclos de ICSI, apresentou um perfil demetilado para esta região. Diferentemente, Khoueiry et al. (2008) observaram semelhantes níveis de metilação nos oócitos maturados in vitro e in vivo, os quais não apresentaram completa metilação, onde as porcentagens de metilação foram entre 61,2 a 66,6 \% nos Vg e MI, sendo que o maior nível de metilação foi encontrado nos oócitos MII com $89,5 \%$ nas amostras maturadas in vivo e $78,3 \%$ após a MIV.

Depois de estabelecido o imprinting nas DMRs, este padrão deve ser mantido durante os eventos de reprogramação que ocorrem no início do desenvolvimento embrionário (Morgan et al., 2005). Devido ao estado monoalélico das ICRs, onde um alelo possui metilação completa e o outro deve estar completamente demetilado de acordo com o progenitor do qual é herdado, o nível de metilação de uma DMR deve ser aproximadamente $50 \%$ nas células somáticas de um indivíduo (Couldrey e Lee, 2010). O resultado nos embriões pré-implantação no estágio de blastocisto, no entanto, não mostrou um perfil monoalélico para a KvDMR1. Nas amostras dos $\mathrm{Bi}$, foi observado um perfil hipermetilado $(80,2 \%)$, e após o crescimento e as sucessivas divisões, nos Bx foi observada uma perda de metilação $(26,4 \%)$ dessa região após aproximadamente um dia de cultivo. 
O controle epigenético do crescimento e desenvolvimento embrionário é um evento orquestrado altamente suscetível a influência do ambiente. O perfil identificado nos $\mathrm{Bi}$ e $\mathrm{Bx}$ podem estar relacionados à inseminação com um oócito com perfil alterado, já que a qualidade do oócito é um fator chave para a proporção dos zigotos que se desenvolvem até o estágio de blastocisto (Lonergan et al., 2006), e ainda a metilação nas ICRs dos oócitos são consideradas fundamentais no estabelecimento do imprinting no embrião (Bourc'his e Bestor, 2004; Wood e Oakey, 2006). A própria cultura e a manipulação durante o período pré-implantacional, pode ter proporcionado uma perda de metilação nessa região ao final do ciclo da PIV, levando a uma expressão aberrante dos genes que sofrem imprinting durante o desenvolvimento (Lonergan et al., 2006; Rivera et al., 2008)

A hipometilacão da KvDMR1 encontrada para os Bx, também foi observada por Couldrey e Lee (2010) e por Hori et al. (2010) utilizando animais adultos provenientes de transferência nuclear e FIV, os quais eram portadores da LOS. Esses resultados podem sugerir que os animais produzidos pelas TRAs podem estar adquirindo um imprinting anormal durante os procedimentos in vitro, o qual pode estar sendo mantido no desenvolvimento fetal. Achado semelhante é encontrado na SBW em humanos, onde cerca de $50 \%$ a $60 \%$ dos casos esporádicos dessa síndrome apresentam perda de metilação da KvDMR1, que leva a uma redução da expressão no CDKN1C e uma expressão bialélica do LIT1 causando alterações de crescimento fetal e pós-natal nas crianças portadoras dessa síndrome (Weksberg et al., 2002; Fitzpatrick et al., 2007).

Outro achado interessante para a KvDMR1 em nossos estudos foi a presença de um sítio CG cujo padrão de metilação não varia em nenhuma das amostras analisadas (Figuras $17 a, 18$ e 19). O ponto 18 de metilação, localizado na posição 198 da região analisada, mostrou-se metilado para todas as amostras analisadas, inclusive nas amostras hipometiladas (espermatozóide). A porcentagem de metilação em cada sítio CG varia dentro de uma mesma região e alguns pontos podem ser mais representativos do que outros para as análises de metilação diferencial (Frost et al., 2010), o que não seria o caso do ponto 18 desse fragmento, visto que está constantemente metilado e possivelmente caracterizaria o final da DMR. No entanto estudos em outros tecidos podem confirmar esse resultado.

O padrão de metilação encontrado para a H19DMR apresentou-se fora do esperado tanto para os oócitos quanto para os blastocistos (Tabela 4). No entanto, para a amostra controle de espermatozóide foi observado um perfil normal de metilação, completamente metilado nos seis clones analisados, corroborando com o padrão de metilação paterno da ICR1. A região contendo os sítios CG analisados compreendeu 10 pontos de metilação que segundo as análises neste estudo e em estudos prévios em nosso laboratório, corresponde a uma região diferencialmente metilada dentro da DMR que seria um suposto sítio de ligação ao CTCF (Rios, 2007). 
As análises nos oócitos mostraram um perfil hipermetilado tanto para o $\mathrm{Vg}(80 \%)$ quanto para o MII (82,5\%), em detrimento a um perfil demetilado esperado para essas amostras. Para os oócitos Vg o perfil encontrado na literatura é correspondente ao perfil demetilado (Borghol et al., 2006). No entanto, Ibala-Romdhane et al. (2011) encontrou um perfil hipermetilado no estágio de $\mathrm{Vg}$, semelhante a este estudo, em humanos por. A amostra Vg que possuía altos níveis de metilação para a H19DMR apresentou um SNP (do inglês, Single Nucleotide Polymorphism) 6236-C que supostamente estaria relacionado a este perfil. $\mathrm{Na}$ análise genotípica, os autores identificaram que o genótipo paterno era homozigoto $\mathrm{C}$ e o materno era heterozigoto $\mathrm{A}$ ou $\mathrm{C}$, em que provavelmente essa alteração de metilação corresponde a um alelo paternalmente herdado que escapou do apagamento durante a oôgenese. Para os oócitos após a MIV (MI e MII), além do perfil considerado normal para a H19DMR (demetilado), também é encontrada hipermetilação e/ou metilação diferencial nessas amostras (Borghol et al., 2006; Ibala-Romdhane et al., 2011).

Os perfis de metilação da H19DMR encontrado nos blastocistos, em contrapartida aos resultados encontrados para a KvDMR1, foram hipometilado nos $\mathrm{Bi}(10,1 \%)$ e hipermetilado nos $\mathrm{Bx}(54,5 \%)$. Essa região, durante o final do desenvolvimento préimplantaçional parece sofrer um ganho de metilação durante o crescimento do $\mathrm{Bi}$, chegando a um estado monoalélico no Bx. Resultados semelhantes foram encontrados por Hori et al.(2010), em que bovinos adultos produzidos por FIV apresentaram um padrão monoalélico para a H19DMR, não diferindo dos animais normais. A expressão bialélica do gene $H 19$, está relacionada com a perda de metilação da ICR1 e tem sido observada em animais produzidos por transferência nuclear, sendo responsável pelo baixo peso ao nascimento e baixa taxa de implantação nos animais clonados (Suzuki et al., 2011).

Os perfis alterados encontrados neste trabalho para os oócitos MII, tanto para a KvDMR1 quanto para a H19DMR, apesar de não corresponder com o esperado, fazem parte de achados importantes para essas regiões em bovinos, já que não há dados a cerca da metilação dessas regiões nessa espécie. Como os resultados encontram-se discrepantes com o sugerido pela literatura, para se confirmar esses achados seriam necessárias novas analises de metilação em outro grupo de oócitos $\mathrm{Vg}$, tendo em vista que este trabalho não realizou repetição amostral, mesmo que o número de clones analisados (8 a 12) corresponda aos padrões exigidos para este tipo de estudo.

A KvDMR1 e H19DMR controlam a expressão de vários genes importantes para o crescimento e desenvolvimento embrionário. Dentre eles o gene LIT1 está sob o controle da KvDMR1, sendo metilado maternalmente e expresso paternalmente. A expressão bialélica desse gene está geralmente relacionada à hipometilação da KvDMR1 e conseqüente silenciamento do gene CDKN1C (Arima et al., 2005; Ager et al., 2008). Outro gene paternalmente expresso, cuja expressão é controlada pela ICR1, é o IGF2. A metilação 
paterna na H19DMR permite a atuação de fatores de transcrição no promotor do gene IGF2, promovendo a sua expressão (Kim et al., 2007).

Com o objetivo de verificar a expressão de alguns genes que estariam relacionados ao padrão de metilação da KvDMR1 e H19DMR os genes LIT1 e IGF2 foram focos neste estudo. As análises de expressão dos genes apresentaram diferentes níveis para as amostras de oócitos e blastocistos (Tabela 2 e Figura 22). A expressão do gene LIT1, apesar dos baixos níveis encontrados, mostrou que este gene encontra-se expresso tanto nos blastocistos $\mathrm{Bi}$ e Bx quanto nos oócitos $\mathrm{Vg}$ e MII, em níveis relativamente semelhantes, sendo ligeiramente mais expresso nos blastocistos. Quanto à expressão do gene IGF2, os blastocistos $\mathrm{Bi}$ e $\mathrm{Bx}$ parecem não expressar esse gene, visto que nenhum sinal de expressão foi detectado para essas amostras. Por outro lado, nos oócitos $\mathrm{Vg}$ e Mll foram detectados níveis substanciais de expressão desse gene, em especial no oócito MII, que apresentou a maior expressão relativa do IGF2 $(4,47)$.

A expressão mais acentuada do IGF2 nos oócitos MII e Vg poderia estar relacionada à hipermetilação da H19DMR encontrada para essas amostras, promovendo uma expressão bialélica desse gene. Devido ao fato desse gene codificar um potente fator de crescimento celular que pode estar sendo requerido durante o crescimento e desenvolvimento oocitário (Ideraabdullah et al., 2008). No entanto a verificação do perfil de expressão do gene $H 19$ poderia ajudar a confirmar esses achados devido à expressão correlacionada desse gene com o IGF2, visto que a alta expressão do IGF2 implica numa expressão reduzida do H19.

A ausência de expressão do gene IGF2 nos blastocistos não estaria relacionada a alterações no padrão de metilação da H19DMR visto que essa região apresentou diferentes perfis de metilação para os $\mathrm{Bi}$ e $\mathrm{Bx}$, hipometilado e monoalélico respectivamente. A verificação da expressão dos genes CDKN1C e H19 poderia estabelecer e/ou confirmar possíveis relações da expressão desses genes com a metilação das DMRs. No trabalho de Hori et al. (2010), nos animais com hipometilação da KvMDR1 foi observada uma expressão alterada do LIT1 e níveis normais de expressão dos genes H19 e IGF2.

Apesar das alterações encontradas nos diferentes estágios dos blastocistos $\mathrm{Bi}$ e $\mathrm{Bx}$, que em contrapartida corroboram com os últimos achados na literatura (Curchoe et al., 2009; Couldrey e Lee, 2010; Hori et al., 2010), foi observado que a KvDMR1 e H19DMR parecem funcionar antagonisticamente. A KvDMR1 tende a uma hipometilação com o avanço do crescimento e desenvolvimento embrionário, mostrando um perfil hipermetilado nos $\mathrm{Bi}$, sendo que essa metilação é reduzida nos Bx. Por outro lado, a H19DMR apresenta um ganho de metilação partindo de um estado hipometilado nos Bi para um estado que se aproxima do perfil monoalélico de expressão dessas DMRs nos Bx, que é normalmente encontrado nas células somáticas de um indivíduo. As alterações de imprinting encontradas durante o desenvolvimento pré-implantacional em bovinos produzidos por FIV podem estar 
relacionadas com a LOS, onde a própria cultura (MIV, FIV e CIV) poderia estar relacionada com a hipometilação da KvDMR1, bem como às alterações encontradas nos oócitos após a maturação.

Importante ressaltar que, até o momento, este é o primeiro trabalho descrevendo o suposto funcionamento dessas DMRs durante o desenvolvimento embrionário de bovinos, bem como na maturação oocitária. Devido à possível conservação do padrão de imprinting dessas DMRs em diferentes espécies (Curchoe et al., 2009), e às semelhanças relacionadas ao desenvolvimento pré-implantacional e a duração da gestação (Hansmann et al., 2010), o modelo bovino parece ser uma alternativa para os estudos de células germinativas e desenvolvimento embrionário em humanos.

\subsection{ANÁLISE COMPARATIVA DO PADRÃO DE METILAÇÃO DAS KvDMR1 e H19DMR EM PLACENTAS PRECOCES BOVINA O HUMANA}

A placenta é um órgão complexo que além de permitir trocas entre a mãe e o feto, atua como eficiente órgão endocrinológico e confere proteção ao feto contra as exposições ambientais e o sistema imune da mãe (Dancis, 1966; Carter, 2007). Mesmo que as placentas, em geral, compartilhem a mesma função, a morfologia e a placentação variam consideravelmente entre as espécies. Apesar dessas diferenças, tem sido relatado que o estado de imprinting e a expressão de alguns genes, parece manter um estado conservado entre as várias espécies, incluindo humanos e bovinos (Bressan et al., 2009; Barreto et al., 2011).

O imprinting genômico está presente em mamíferos placentários e desempenham importante papel no desenvolvimento da placenta e, consequentemente do feto, podendo estar diretamente relacionado com a aquisição desse órgão durante a evolução de mamíferos, sendo que muitas explicações para a evolução do imprinting sugerem a placenta como um tecido chave no desenvolvimento (Monk et al., 2006). As alterações de imprinting na placenta podem levar a sérios impactos no desenvolvimento do feto, tendo em vista que esses genes afetam o crescimento e a morfologia placentária, bem como e a capacidade de transferência, atuando diretamente no controle de nutrientes para o crescimento fetal (Fowden et al., 2011).

Devido a este órgão ser um importante alvo do imprinting e à importância de se conhecer o funcionamento desses genes em diferentes espécies e em diferentes fases do desenvolvimento, na tentativa de se encontrar modelos animais para estudos de placentação, bem como na busca das bases moleculares das doenças gestacionais $(\mathrm{Ng}$ et al., 2010; Fowden et al., 2011), neste trabalho foi analisado o padrão de imprinting da 
KvDMR1 e H19DMR em tecido placentário de bovinos e humanos, visando verificar as possíveis similaridades entre essas duas espécies.

As placentas de bovinos e humanos são diferentes estrutural e morfologicamente. Em humanos, a placentação é hemocorial com extensiva invasão do trofoblasto durante o desenvolvimento que remodela as artérias maternas maximizando o fluxo sanguíneo para o espaço interviloso. Por outro lado, a placentação em bovinos é sinepiteliocorial onde as células do trofoblasto estão em contato direto com as células epiteliais da superfície do útero, sendo que não há invasão do trofoblasto além dessa camada (Moffett e Loke, 2006; $\mathrm{Ng}$ et al., 2010). Esse contato materno-fetal nas placentas de bovinos é dado por um variado número de placentomas, que são emaranhados de vilosidade fetal, denominados cotilédones, em uma crista materna, denominada carúncula (Wooding et al., 1997).

Com relação às análises de metilação para a KvDMR1 e H19DMR o resultado da similaridade entre as sequências analisadas mostrou um grau considerado satisfatório (>25\%), que pode sugerir conservação entre essas duas espécies. As análises de metilação nos cotilédones provenientes da gestação de $49 \mathrm{~d}$, mostraram que as duas regiões, como nos resultados apresentados para os embriões pré-implantação, apresentam um padrão de metilação inversamente proporcional entre elas, visto que, enquanto a metilação na KvDMR1 está aumentada em uma dada amostra, a H19DMR encontra-se mais demetilada.

O perfil de metilação entre os cotilédones variou entre as diferentes amostras para as duas DMRs analisadas. Para a KvDMR1, foi observada uma tendência a hipermetilação para os Co 1 e Co 3 (88,9\% e 91,1\%), e os Co 2 e Co 4 (56,9\% e $39,6 \%$ ) apresentaram níveis mais reduzidos de metilação, aproximando-se do perfil monoalélico. Até o momento não foram encontrados dados na literatura acerca do perfil de metilação da KvDMR1 em placentas de bovinos.

A H19DMR nos cotilédones mostrou um perfil que se aproxima do monoalélico, onde o nível de metilação encontrado variou entre 35\% e 57\%. Somente uma amostra apresentou um perfil completamente demetilado, o Co 2. Hansmann et al. (2010) analisou três possíveis sítios de ligação do CTCF para a H19DMR em placentas de bovinos e observou semelhantes resultados como encontrado nesse trabalho, onde a porcentagem de metilação variou entre $47 \%$ a $51 \%$ para os três sítios analisados. Em contrapartida, Couldrey e Lee (2010) encontraram hipermetilação da H19DMR variando entre $70 \%$ a 100\%, nas amostras controles e provenientes de transferência nuclear.

Quando se compara esses resultados com os encontrados no embrião de 49d notase que o embrião mostrou um perfil que se assemelha ao hipermetilado para a KvMDR1, semelhante aos Co 1 e Co 3. Couldrey e Lee (2010), em contrapartida identificaram uma hipometilação que variou entre $0-45 \%$ de metilação em amostras de tecido fetal (rim, pulmão 
e adrenal), com aproximadamente 120 dias de idade gestacional, nos grupos controle. O embrião de 49d para a H19DMR apresentou um perfil hipometilado, o que se aproxima do encontrado para o Co 1. Para todas as amostras analisadas, foi observado novamente um padrão metilado para o ponto 18 dessa região, confirmando os achados para os oócitos e blastocistos, sugerindo que esse ponto possa estar fora da DMR bovina.

Os placentomas variam em número e tamanho entre as espécies (Wooding et al., 1997). As diferenças de metilação encontradas entre os cotilédones podem estar relacionadas ao fato de que a placenta apresenta-se como um mosaico, onde a expressão dos genes que sofrem imprinting são espaço e tempo específicos. O padrão de imprinting placentário pode apresentar variações durante e entre as gestações em humanos, murinos e bovinos (Coan et al., 2005; Pozharny et al., 2010). Como exemplo, o gene MASH2 (ou ASCL2, do inglês Achaete-Scute Complex Homolog 2) de bovinos, que estimula a proliferação celular e inibe a progressão do trofoblasto, tem expressão limitada a placenta, o qual é bialelicamente expresso no trofoblasto, e após a implantação esse gene é paternalmente silenciado (Arnold et al., 2006). O perfil de metilação encontrado para essas DMRs, ao longo do crescimento fetal e placentário pode variar, e estudos durante as diferentes fases gestacionais ajudariam a estabelecer o padrão de imprinting dessas regiões.

Nas análises em humanos, foi observado que as regiões KvDMR1 e H19DMR apresentaram um padrão semelhante de metilação para todas as amostras das vilosidades da placenta de 12 semanas. A porcentagem de metilação não variou substancialmente entre as duas regiões, nem mesmo entre as diferentes vilosidades analisadas, em que o menor nível de metilação observado foi de $84,4 \%$ e o nível mais alto foi de 97,9\%. Diferentemente, Bourque et al. (2010) mostrou um perfil de metilação para a H19DMR com média de 36,4\% (hipometilado) utilizando placentas de humanos a termo, normais e com restrição de crescimento intra-uterino, a qual não variou entre as amostras.

Alguns estudos têm mostrado LOI em placentas humanas, no entanto pouco se sabe a cerca desse mecanismo em placentas precoces. Em contraposição aos achados deste trabalho, um dos primeiros estudos que mostrou o perfil de imprinting em placentas de primeiro trimestre foi realizado por Pozharny et al. (2010), em que os autores observaram uma alta taxa de LOI para a maioria dos genes analisados (14). Dentre eles, o gene H19 apresentou uma taxa de LOI (5-10\%) nas placentas precoces, quando comparadas com as placentas a termo, e o único gene 
apresentou uma reduzida taxa de LOI foi o IGF2. A região KvDMR1 não foi analisada nesses estudos.

Estudos em modelos para a regulação gênica têm sido empregados com principal foco modelo de camundongos. Pouco se conhece a cerca dessas comparações entre bovinos e humanos, e apesar das semelhanças com relação ao padrão de metilação da KvDMR1 e H19DMR nas espécies estudadas nos demais tecidos, o imprinting na placenta parece variar. As maiores semelhanças encontradas entre bovinos e humanos foi com relação a KvDMR1, em que, apesar de variar ente os cotilédones de bovinos, duas amostras apresentaram um perfil hipermetilado semelhante ao perfil encontrado nas vilosidades de humanos. Os resultados para a H19DMR de bovinos e humanos foram divergentes, onde em bovinos foi observado um baixo nível de metilação nos cotilédones analisados, em contraposição, em humanos foi observado um perfil semelhante ao da região KvDMR1, ou seja, hipermetilado.

Possivelmente, essas regiões não apresentam uma relação de metilação no tecido placentário, principalmente para a H19DMR, ou ainda, o número de clones analisados para essa região poderia ser aumentado, visto que para algumas amostras não foi possível estabelecer o padrão de 8 clones, devido a falhas no sequênciamento. Essas análises podem ajudar a desvendar o perfil de imprinting na placenta de bovinos e humanos e, estudos durante as diferentes fases do desenvolvimento fetal e placentário seriam interessantes, visto que a placenta é um órgão extremamente importante para o crescimento e desenvolvimento fetal. 
CONCLUSÕES 


\section{CONCLUSÕES}

Os oócitos não maturados apresentaram um perfil normal hipermetilado para a KvDMR1 e um perfil alterado hipermetilado para a H19DMR. Nos oócitos após a MIV foi encontrada uma alteração no padrão de metilação para as duas regiões analisadas, sendo monoalélico para KvDMR1 e hipermetilado para a H19DMR.

O perfil encontrado para os blastocistos iniciais foi hipermetilado para a KvDMR1 e hipometilado para a H19DMR. Em contraposição, para os blastocistos expandidos foi encontrado um perfil hipometilado para a KvDMR1 e monoalélico para a H19DMR.

A análise de expressão gênica mostrou níveis semelhantes de expressão do gene LIT1 nas amostras de oócitos não maturados e maturados in vitro, bem como nos blastocistos inicial e expandido. O gene IGF2 não foi expresso nas amostras de blastocistos, sendo que sua expressão foi detectada somente nos oócitos, com maiores valores de expressão nos oócitos maturados in vitro.

As análises de metilação da KvMDR1 e H19DMR e da expressão dos genes LIT1 e IGF2 não apresentaram correlação. Somente na amostra dos oócitos maturados in vitro, os altos níveis de expressão do IGF2 podem estar relacionados ao perfil hipermetilado encontrado para a H19DMR.

A KvDMR1 apresentou um perfil hipermetilado para o embrião de 49d. Nos cotilédones os perfis encontrados foram variados, contendo amostras hipermetiladas, hipometiladas e monoalélicas.

O perfil de metilação da H19DMR no embrião bovino foi hipometilado. Nos cotilédones os perfis observados foram hipometilado e monoalélico.

Nas placentas precoces de humanos foi observado um perfil hipermetilado para a KvDMR1 e H19DMR.

Não foi possível estabelecer uma relação do perfil de metilação placentário da KvDMR1 e H19DMR entre bovinos e humanos. 
REFERÊNCIAS 


\section{REFERÊNCIAS}

Ager, E. I.; Pask, A. J.; Gehring, H. M. et al. (2008). Evolution of the CDKN1C-KCNQ1 imprinted domain. BMC Evol Biol 8: 163.

Anckaert, E.; Adriaenssens, T.; Romero, S. et al. (2009). Unaltered imprinting establishment of key imprinted genes in mouse oocytes after in vitro follicle culture under variable follicle-stimulating hormone exposure. Int J Dev Biol 53(4): 541-8.

Antunes, G.; Marques, A.; Santos, P. et al. (2008). Atlas do ovócito e do embrião bovino, Principia.

Arima, T.; Kamikihara, T.; Hayashida, T. et al. (2005). ZAC, LIT1 (KCNQ1OT1) and p57KIP2 (CDKN1C) are in an imprinted gene network that may play a role in BeckwithWiedemann syndrome. Nucleic Acids Res 33(8): 2650-60.

Arnold, D. R.; Lefebvre, R. \& Smith, L. C. (2006). Characterization of the placenta specific bovine mammalian achaete scute-like homologue 2 (Mash2) gene. Placenta 27(1112): 1124-31.

Barreto, R. S.; Bressan, F. F.; Oliveira, L. J. et al. (2011). Gene expression in placentation of farm animals: an overview of gene function during development. Theriogenology 76(4): 589-97.

Beatty, L.; Weksberg, R. \& Sadowski, P. D. (2006). Detailed analysis of the methylation patterns of the KvDMR1 imprinting control region of human chromosome 11. Genomics 87(1): 46-56.

Bell, A. C. \& Felsenfeld, G. (2000). Methylation of a CTCF-dependent boundary controls imprinted expression of the lgf2 gene. Nature 405(6785): 482-5.

Bestor, T. H. (2000). The DNA methyltransferases of mammals. Hum Mol Genet 9(16): 2395402.

Bird, A. (2002). DNA methylation patterns and epigenetic memory. Genes Dev 16(1): 6-21.

Borghol, N.; Lornage, J.; Blachere, T. et al. (2006). Epigenetic status of the H19 locus in human oocytes following in vitro maturation. Genomics 87(3): 417-26.

Bourc'his, D. \& Bestor, T. H. (2004). Meiotic catastrophe and retrotransposon reactivation in male germ cells lacking Dnmt3L. Nature 431(7004): 96-9.

Bourque, D. K.; Avila, L.; Penaherrera, M. et al. (2010). Decreased placental methylation at the H19/IGF2 imprinting control region is associated with normotensive intrauterine growth restriction but not preeclampsia. Placenta 31(3): 197-202. 
Bressan, F. F.; De Bem, T. H.; Perecin, F. et al. (2009). Unearthing the roles of imprinted genes in the placenta. Placenta 30(10): 823-34.

Buiting, K. (2010). Prader-Willi syndrome and Angelman syndrome. Am J Med Genet C Semin Med Genet 154C(3): 365-76.

Carter, A. M. (2007). Animal models of human placentation--a review. Placenta 28 Suppl A: S41-7.

Coan, P. M.; Burton, G. J. \& Ferguson-Smith, A. C. (2005). Imprinted genes in the placenta-a review. Placenta 26 Suppl A: S10-20.

Cohen, M. M., Jr. (2005). Beckwith-Wiedemann syndrome: historical, clinicopathological, and etiopathogenetic perspectives. Pediatr Dev Pathol 8(3): 287-304.

Constant, F.; Guillomot, M.; Heyman, Y. et al. (2006). Large offspring or large placenta syndrome? Morphometric analysis of late gestation bovine placentomes from somatic nuclear transfer pregnancies complicated by hydrallantois. Biol Reprod 75(1): 122-30.

Corpet, F. (1988). Multiple sequence alignment with hierarchical clustering. Nucleic Acids Res 16(22): 10881-90.

Corry, G. N.; Tanasijevic, B.; Barry, E. R. et al. (2009). Epigenetic regulatory mechanisms during preimplantation development. Birth Defects Res C Embryo Today 87(4): 297313.

Couldrey, C. \& Lee, R. S. (2010). DNA methylation patterns in tissues from mid-gestation bovine foetuses produced by somatic cell nuclear transfer show subtle abnormalities in nuclear reprogramming. BMC Dev Biol 10: 27.

Curchoe, C.; Zhang, S.; Bin, Y. et al. (2005). Promoter-specific expression of the imprinted IGF2 gene in cattle (Bos taurus). Biol Reprod 73(6): 1275-81.

Curchoe, C. L.; Zhang, S.; Yang, L. et al. (2009). Hypomethylation trends in the intergenic region of the imprinted IGF2 and H19 genes in cloned cattle. Anim Reprod Sci 116(34): 213-25.

Dancis, J. (1966). The placenta. A multicategorical, interdisciplinary phenenon. (Borden Award addres). Pediatrics 38(2): 167-72.

Das, R.; Hampton, D. D. \& Jirtle, R. L. (2009). Imprinting evolution and human health. Mamm Genome 20(9-10): 563-72. 
Dean, W.; Santos, F.; Stojkovic, M. et al. (2001). Conservation of methylation reprogramming in mammalian development: aberrant reprogramming in cloned embryos. Proc Natl Acad Sci U S A 98(24): 13734-8.

DeBaun, M. R.; Niemitz, E. L. \& Feinberg, A. P. (2003). Association of in vitro fertilization with Beckwith-Wiedemann syndrome and epigenetic alterations of LIT1 and H19. Am J Hum Genet 72(1): 156-60.

Diplas, A. I.; Lambertini, L.; Lee, M. J. et al. (2009). Differential expression of imprinted genes in normal and IUGR human placentas. Epigenetics 4(4): 235-40.

Edwards, C. A. \& Ferguson-Smith, A. C. (2007). Mechanisms regulating imprinted genes in clusters. Curr Opin Cell Biol 19(3): 281-9.

Eggermann, T.; Schonherr, N.; Meyer, E. et al. (2006). Epigenetic mutations in 11p15 in Silver-Russell syndrome are restricted to the telomeric imprinting domain. J Med Genet 43(7): 615-6.

Engemann, S.; Strodicke, M.; Paulsen, M. et al. (2000). Sequence and functional comparison in the Beckwith-Wiedemann region: implications for a novel imprinting centre and extended imprinting. Hum Mol Genet 9(18): 2691-706.

Farin, P. W.; Piedrahita, J. A. \& Farin, C. E. (2006). Errors in development of fetuses and placentas from in vitro-produced bovine embryos. Theriogenology 65(1): 178-91.

Fitzpatrick, G. V.; Pugacheva, E. M.; Shin, J. Y. et al. (2007). Allele-specific binding of CTCF to the multipartite imprinting control region KvDMR1. Mol Cell Biol 27(7): 2636-47.

Fowden, A. L.; Coan, P. M.; Angiolini, E. et al. (2011). Imprinted genes and the epigenetic regulation of placental phenotype. Prog Biophys Mol Biol 106(1): 281-8.

Frost, J. M.; Monk, D.; Stojilkovic-Mikic, T. et al. (2010). Evaluation of allelic expression of imprinted genes in adult human blood. PLoS One 5(10): e13556.

Galli, C. \& Lazzari, G. (2008). The manipulation of gametes and embryos in farm animals. Reprod Domest Anim 43 Suppl 2: 1-7.

Geiman, T. M. \& Muegge, K. (2010). DNA methylation in early development. Mol Reprod Dev 77(2): 105-13.

Geuns, E.; Hilven, P.; Van Steirteghem, A. et al. (2007). Methylation analysis of KvDMR1 in human oocytes. J Med Genet 44(2): 144-7. 
Gomes, M. V.; Gomes, C. C.; Pinto, W., Jr. et al. (2007). Methylation pattern at the KvDMR in a child with Beckwith-Wiedemann syndrome conceived by ICSI. Am J Med Genet A 143(6): 625-9.

Gude, N. M.; Roberts, C. T.; Kalionis, B. et al. (2004). Growth and function of the normal human placenta. Thromb Res 114(5-6): 397-407.

Haig, D. (2004). The (dual) origin of epigenetics. Cold Spring Harb Symp Quant Biol 69: 6770.

Hall, T. A. (1999). BioEdit: a user-friendly biological sequence alignment editor and analysis program for Windows 95/98/NT. Nucleic Acids Symposium Series(41): 95 - 98.

Hansmann, T.; Heinzmann, J.; Wrenzycki, C. et al. (2010). Characterization of differentially methylated regions in 3 bovine imprinted genes: a model for studying human germcell and embryo development. Cytogenet Genome Res 132(4): 239-47.

Herman, J. G.; Graff, J. R.; Myohanen, S. et al. (1996). Methylation-specific PCR: a novel PCR assay for methylation status of CpG islands. Proc Natl Acad Sci U S A 93(18): 9821-6.

Hori, N.; Nagai, M.; Hirayama, M. et al. (2010). Aberrant CpG methylation of the imprinting control region KvDMR1 detected in assisted reproductive technology-produced calves and pathogenesis of large offspring syndrome. Anim Reprod Sci 122(3-4): 303-12.

Horike, S.; Mitsuya, K.; Meguro, M. et al. (2000). Targeted disruption of the human LIT1 locus defines a putative imprinting control element playing an essential role in Beckwith-Wiedemann syndrome. Hum Mol Genet 9(14): 2075-83.

Ibala-Romdhane, S.; Al-Khtib, M.; Khoueiry, R. et al. (2011). Analysis of H19 methylation in control and abnormal human embryos, sperm and oocytes. Eur J Hum Genet 19(11): 1138-43.

Ideraabdullah, F. Y.; Vigneau, S. \& Bartolomei, M. S. (2008). Genomic imprinting mechanisms in mammals. Mutat Res 647(1-2): 77-85.

Iliadou, A. N.; Janson, P. C. \& Cnattingius, S. (2011). Epigenetics and assisted reproductive technology. J Intern Med 270(5): 414-20.

Jaenisch, R. \& Bird, A. (2003). Epigenetic regulation of gene expression: how the genome integrates intrinsic and environmental signals. Nat Genet 33 Suppl: 245-54.

Jirtle, R. L. \& Weidman, J. R. (2007). Imprinted and More Equal American Scientist 95: 143-149. 
Khosla, S.; Dean, W.; Reik, W. et al. (2001). Culture of preimplantation embryos and its longterm effects on gene expression and phenotype. Hum Reprod Update 7(4): 419-27.

Khoueiry, R.; Ibala-Rhomdane, S.; Mery, L. et al. (2008). Dynamic CpG methylation of the KCNQ1OT1 gene during maturation of human oocytes. J Med Genet 45(9): 583-8.

Kiefer, J. C. (2007). Epigenetics in development. Dev Dyn 236(4): 1144-56.

Kim, T. H.; Abdullaev, Z. K.; Smith, A. D. et al. (2007). Analysis of the vertebrate insulator protein CTCF-binding sites in the human genome. Cell 128(6): 1231-45.

Kumaki, Y.; Oda, M. \& Okano, M. (2008). QUMA: quantification tool for methylation analysis. Nucleic Acids Res 36(Web Server issue): W170-5.

Kurihara, Y.; Kawamura, Y.; Uchijima, Y. et al. (2008). Maintenance of genomic methylation patterns during preimplantation development requires the somatic form of DNA methyltransferase 1. Dev Biol 313(1): 335-46.

Leighton, P. A.; Ingram, R. S.; Eggenschwiler, J. et al. (1995). Disruption of imprinting caused by deletion of the $\mathrm{H} 19$ gene region in mice. Nature 375(6526): 34-9.

Lewis, A. \& Reik, W. (2006). How imprinting centres work. Cytogenet Genome Res 113(1-4): 81-9.

Li, L. C. \& Dahiya, R. (2002). MethPrimer: designing primers for methylation PCRs. Bioinformatics 18(11): 1427-31.

Li, M.; Squire, J. A. \& Weksberg, R. (1998). Overgrowth syndromes and genomic imprinting: from mouse to man. Clin Genet 53(3): 165-70.

Lin, L.; Li, Q.; Zhang, L. et al. (2008). Aberrant epigenetic changes and gene expression in cloned cattle dying around birth. BMC Dev Biol 8: 14.

Livak, K. J. \& Schmittgen, T. D. (2001). Analysis of relative gene expression data using realtime quantitative PCR and the 2(-Delta Delta C(T)) Method. Methods 25(4): 402-8.

Lonergan, P. \& Fair, T. (2008). In vitro-produced bovine embryos-Dealing with the warts. Theriogenology 69: 17-22.

Lonergan, P.; Fair, T.; Corcoran, D. et al. (2006). Effect of culture environment on gene expression and developmental characteristics in IVF-derived embryos. Theriogenology 65(1): 137-52. 
Lucifero, D.; Mann, M. R.; Bartolomei, M. S. et al. (2004). Gene-specific timing and epigenetic memory in oocyte imprinting. Hum Mol Genet 13(8): 839-49.

Maher, E. R. (2005). Imprinting and assisted reproductive technology. Hum Mol Genet 14 Spec No 1: R133-8.

Maher, E. R.; Brueton, L. A.; Bowdin, S. C. et al. (2003). Beckwith-Wiedemann syndrome and assisted reproduction technology (ART). J Med Genet 40(1): 62-4.

Manipalviratn, S.; DeCherney, A. \& Segars, J. (2009). Imprinting disorders and assisted reproductive technology. Fertil Steril 91(2): 305-15.

Marteil, G.; Richard-Parpaillon, L. \& Kubiak, J. Z. (2009). Role of oocyte quality in meiotic maturation and embryonic development. Reprod Biol 9(3): 203-24.

Mayer, W.; Niveleau, A.; Walter, J. et al. (2000). Demethylation of the zygotic paternal genome. Nature 403(6769): 501-2.

Mitsuya, K.; Meguro, M.; Lee, M. P. et al. (1999). LIT1, an imprinted antisense RNA in the human KVLQT1 locus identified by screening for differentially expressed transcripts using monochromosomal hybrids. Hum Mol Genet 8(7): 1209-17.

Moffett, A. \& Loke, C. (2006). Immunology of placentation in eutherian mammals. Nat Rev Immunol 6(8): 584-94.

Mohammad, F.; Mondal, T. \& Kanduri, C. (2009). Epigenetics of imprinted long noncoding RNAs. Epigenetics 4(5): 277-86.

Monk, D.; Arnaud, P.; Apostolidou, S. et al. (2006). Limited evolutionary conservation of imprinting in the human placenta. Proc Natl Acad Sci U S A 103(17): 6623-8.

Monk, M.; Boubelik, M. \& Lehnert, S. (1987). Temporal and regional changes in DNA methylation in the embryonic, extraembryonic and germ cell lineages during mouse embryo development. Development 99(3): 371-82.

Morgan, H. D.; Santos, F.; Green, K. et al. (2005). Epigenetic reprogramming in mammals. Hum Mol Genet 14 Spec No 1: R47-58.

Murphy, S. K. \& Jirtle, R. L. (2003). Imprinting evolution and the price of silence. Bioessays 25(6): 577-88. 
Ng, H. K.; Novakovic, B.; Hiendleder, S. et al. (2010). Distinct patterns of gene-specific methylation in mammalian placentas: implications for placental evolution and function. Placenta 31 259-268.

Niemitz, E. L. \& Feinberg, A. P. (2004). Epigenetics and assisted reproductive technology: a call for investigation. Am J Hum Genet 74(4): 599-609.

Noden DM, d. L. A. (1990). Extraembryonic membranes and placentation. . In: Noden DM, de Lahunta A, The Embryology of Domestic Animals. Baltimore: Williams and Wilkins 47-69.

O'Doherty, A. M.; O'Shea, L. C. \& Fair, T. (2011). Bovine DNA Methylation Imprints Are Established in an Oocyte Size-Specific Manner, Which Are Coordinated with the Expression of the DNMT3 Family Proteins. Biol Reprod.

Olerup, O. \& Zetterquist, H. (1992). HLA-DR typing by PCR amplification with sequencespecific primers (PCR-SSP) in 2 hours: an alternative to serological DR typing in clinical practice including donor-recipient matching in cadaveric transplantation. Tissue Antigens 39(5): 225-35.

Owen, C. M. \& Segars, J. H., Jr. (2009). Imprinting disorders and assisted reproductive technology. Semin Reprod Med 27(5): 417-28.

Paoloni-Giacobino, A. (2006). Implications of reproductive technologies for birth and developmental outcomes: imprinting defects and beyond. Expert Rev Mol Med 8(12): $1-14$

Pozharny, Y.; Lambertini, L.; Ma, Y. et al. (2010). Genomic loss of imprinting in first-trimester human placenta. Am J Obstet Gynecol 202(4): 391 e1-8.

Reik, W.; Dean, W. \& Walter, J. (2001). Epigenetic reprogramming in mammalian development. Science 293(5532): 1089-93.

Reik, W.; Santos, F. \& Dean, W. (2003). Mammalian epigenomics: reprogramming the genome for development and therapy. Theriogenology 59(1): 21-32.

Rinkenberger, J. L.; Cross, J. C. \& Werb, Z. (1997). Molecular genetics of implantation in the mouse. Dev Genet 21(1): 6-20.

Rios, A. F. L. (2007). Caracterização in silico e análise epigenética em bovinos produzidos in vitro e por transferência nuclear da ragião homóloga à 11 p15.5 envolvida com a síndrome de Beckwith-Wiedemann em humanos. Tese (Doutorado): 116. 
Rivera, R. M.; Stein, P.; Weaver, J. R. et al. (2008). Manipulations of mouse embryos prior to implantation result in aberrant expression of imprinted genes on day 9.5 of development. Hum Mol Genet 17(1): 1-14.

Rosenkrans, C. F., Jr. \& First, N. L. (1994). Effect of free amino acids and vitamins on cleavage and developmental rate of bovine zygotes in vitro. J Anim Sci 72(2): 434-7.

Sato, A.; Otsu, E.; Negishi, H. et al. (2007). Aberrant DNA methylation of imprinted loci in superovulated oocytes. Hum Reprod 22(1): 26-35.

Surani, M. A. (2001). Reprogramming of genome function through epigenetic inheritance. Nature 414(6859): 122-8.

Surani, M. A.; Barton, S. C. \& Norris, M. L. (1984). Development of reconstituted mouse eggs suggests imprinting of the genome during gametogenesis. Nature 308(5959): 548-50.

Suzuki, J., Jr.; Therrien, J.; Filion, F. et al. (2011). Loss of methylation at H19 DMD is associated with biallelic expression and reduced development in cattle derived by somatic cell nuclear transfer. Biol Reprod 84(5): 947-56.

Thompson, J. G. (1997). Comparison between in vivo-derived and in vitro-produced preelongation embryos from domestic ruminants. Reprod. Fertil. Dev. 9: 341-54.

Tilghman, S. M. (1999). The sins of the fathers and mothers: genomic imprinting in mammalian development. Cell 96(2): 185-93.

Trasler, J. M. (2006). Gamete imprinting: setting epigenetic patterns for the next generation. Reprod Fertil Dev 18(1-2): 63-9.

Tycko, B. (2006). Imprinted genes in placental growth and obstetric disorders. Cytogenet Genome Res 113(1-4): 271-8.

Unceia (1998). Services techiniques laboratoire de fecondation in vitro. . Petit atlas de I' ovocite bovin.: 1-8.

van Tol, H. T.; van Eerdenburg, F. J.; Colenbrander, B. et al. (2008). Enhancement of Bovine oocyte maturation by leptin is accompanied by an upregulation in mRNA expression of leptin receptor isoforms in cumulus cells. Mol Reprod Dev 75(4): 578-87.

Vassena, R.; Dee Schramm, R. \& Latham, K. E. (2005). Species-dependent expression patterns of DNA methyltransferase genes in mammalian oocytes and preimplantation embryos. Mol Reprod Dev 72(4): 430-6. 
Waddington, C. H. (1942). Canalization of development and the inheritance of the acquired characters. Nature 150(3811): 563-565.

Wadhwa, P. D.; Buss, C.; Entringer, S. et al. (2009). Developmental origins of health and disease: brief history of the approach and current focus on epigenetic mechanisms. Semin Reprod Med 27(5): 358-68.

Wagschal, A. \& Feil, R. (2006). Genomic imprinting in the placenta. Cytogenet Genome Res 113(1-4): 90-8.

Wang, Z.; Schones, D. E. \& Zhao, K. (2009). Characterization of human epigenomes. Curr Opin Genet Dev 19(2): 127-34.

Weksberg, R.; Shuman, C.; Caluseriu, O. et al. (2002). Discordant KCNQ1OT1 imprinting in sets of monozygotic twins discordant for Beckwith-Wiedemann syndrome. Hum Mol Genet 11(11): 1317-25.

Wood, A. J. \& Oakey, R. J. (2006). Genomic imprinting in mammals: emerging themes and established theories. PLoS Genet 2(11): e147.

Wooding, F. B.; Morgan, G. \& Adam, C. L. (1997). Structure and function in the ruminant synepitheliochorial placenta: central role of the trophoblast binucleate cell in deer. Microsc Res Tech 38(1-2): 88-99.

Wrenzycki, C.; Herrmann, D.; Lucas-Hahn, A. et al. (2005). Epigenetic reprogramming throughout preimplantation development and consequences for assisted reproductive technologies. Birth Defects Res C Embryo Today 75(1): 1-9.

Young, L. E.; Fernandes, K.; McEvoy, T. G. et al. (2001). Epigenetic change in IGF2R is associated with fetal overgrowth after sheep embryo culture. Nat Genet 27(2): 153-4.

Young, L. E.; Sinclair, K. D. \& Wilmut, I. (1998). Large offspring syndrome in cattle and sheep. Rev Reprod 3(3): 155-63.

Yu, L.; Chen, M.; Zhao, D. et al. (2009). The H19 gene imprinting in normal pregnancy and pre-eclampsia. Placenta 30(5): 443-7.

Zaitoun, I. \& Khatib, H. (2008). Comparative genomic imprinting and expression analysis of six cattle genes. J Anim Sci 86(1): 25-32.

Zhuo, L. \& Kimata, K. (2001). Cumulus oophorus extracellular matrix: its construction and regulation. Cell Struct Funct 26(4): 189-96. 


\section{APÊNDICE}

\section{Alinhamento e similaridade entre as sequencias}

As DMRs estudadas foram alinhadas e os resultados do alinhamento e da similaridade entre as sequências de bovino e humanos, para a KvDMR1 e H19DMR, estão apresentadas na figura 29.

a

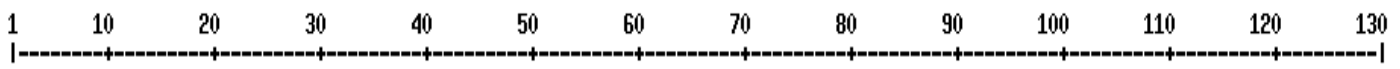

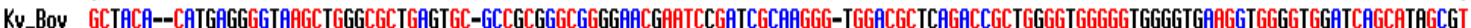

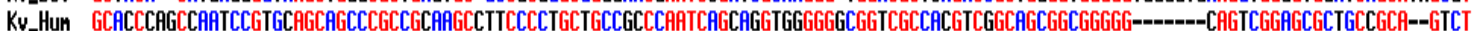

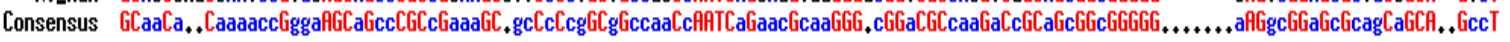

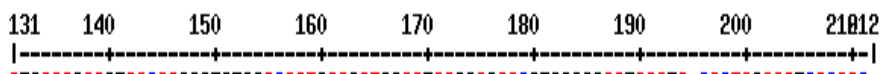

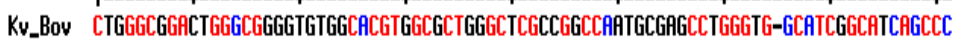

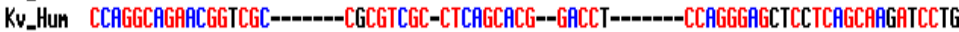

Consensus CcaGGCaGflacGGgCGc......... CaCGTcGC.CTcaGCaCG., GaCCa........CCaGGGaG.gCaTCaGCHacflgCC..

b

\begin{tabular}{|c|c|c|c|c|c|c|c|c|c|c|c|c|c|c|}
\hline & 1 & 10 & 20 & 30 & 40 & 50 & 60 & 70 & 80 & 90 & 100 & 110 & 120 & 130 \\
\hline \multirow[t]{2}{*}{$\begin{array}{r}\text { H19_Bov } \\
\text { H9_Hun } \\
\text { Consensus }\end{array}$} & \multicolumn{14}{|c|}{ 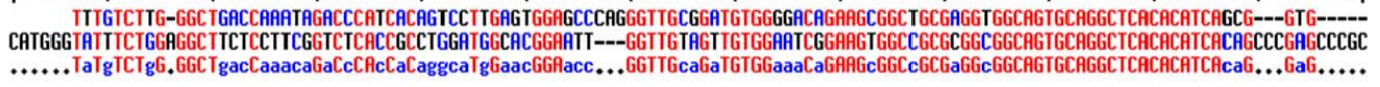 } \\
\hline & 131 & 140 & 150 & 160 & 170 & 180 & 190 & 200 & 210 & 220 & 230 & 240 & 250 & 260 \\
\hline \multirow[t]{2}{*}{$\begin{array}{r}\text { H19_Bov } \\
\text { H9_Hun } \\
\text { Consensus }\end{array}$} & \multicolumn{14}{|c|}{ 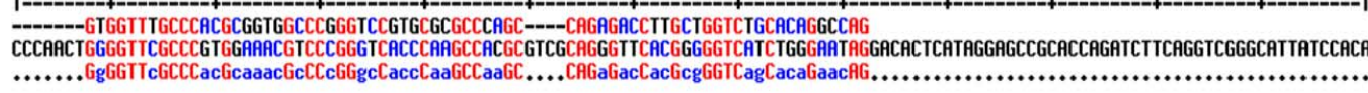 } \\
\hline & 261 & 270 & 280 & 290 & 300 & 310 & & & & & & & & \\
\hline
\end{tabular}

Figura 29: Alinhamento dos segmentos analisados em bovinos e humanos. a) Alinhamento da KvDMR1. b) Alinhamento da H19DMR.

O alinhamento da KvDMR1 de bovinos e humanos, mostrou uma similaridade entre as seqüências que correspondeu a $51 \%$ de identidade. Para a H19DMR, foi encontrado um grande gap no final da sequência, devido ao tamanho dos segmentos analisados para as duas regiões, correspondendo a 186pb para bovinos e $311 \mathrm{pb}$ para humanos. Removendo esse gap o resultado da similaridade entre os segmentos analisados correspondente a H19DMR foi de 55\% de identidade. 
ANEXO 
ANEXO

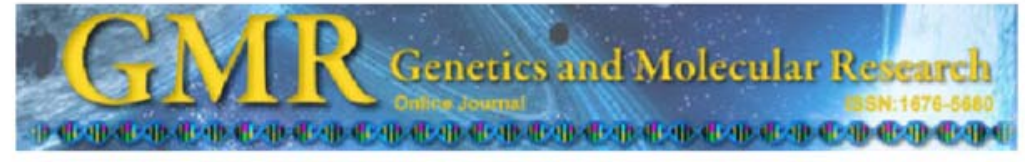

\section{Sexing single bovine blastomeres using TSPY gene amplification}

M.C.A. Carneiro ${ }^{1.2}$, P.L. Takeuchi', A. Araújo ${ }^{1}$, R.B. Lôbo' ${ }^{1}$, F.P. Elias', R.A. Vila', C.L. Miranda-Furtado ${ }^{1}$ and E.S. Ramos ${ }^{13}$

'Departamento de Genética, Faculdade de Medicina de Ribeirão Preto, Universidade de São Paulo, Ribeirão Preto, SP, Brasil

2Departamento de Biologia,

Faculdade de Filosofia, Ciências e Letras de Ribeirão Preto,

Universidade de São Paulo, Ribeirão Preto, SP, Brasil

${ }^{3}$ Departamento de Ginecologia e Obstetrícia,

Faculdade de Medicina de Ribeirão Preto,

Universidade de São Paulo, Ribeirão Preto, SP, Brasil

Corresponding author: E.S. Ramos

E-mail: esramos@genbov.fmrp.usp.br

Genet. Mol. Res. (2011) Ahead of Print

Received April 27, 2011

Accepted August 31, 2011

Published October 25, 2011

DOI http://dx.doi.org/10.4238/2011.October.25.1

ABSTRACT. The testis-specific protein Y-encoded gene (TSPY) is a Y-specific gene present in variable copy number in many mammalian species, including cattle. We tested the applicability of the TSPY gene as a Y-specific marker to predict preimplantation embryo sex in Nelore (Bos indicus) cattle. Two blastomeres were removed from each embryo. A total of 36 single blastomeres and the remaining cells of their 18 matched in vitro conceived embryos were screened for TSPY amplification by nested-PCR. The results obtained from a single blastomere and the remaining cells of the same embryo were concordant in all cases. All blastomeres (16/16) from eight embryos produced with sexed sperm (specific for production of male embryos) were TSPY-positive. We conclude that TSPY is a good male-specific marker, the usefulness of which is probably enhanced by the high copy number. Other methods that are less time-consuming, such as real-time 
M.C.A. Carneiro et al.

PCR, could be improved with the use of the TSPY gene sequences to generate primers and/or probes. This is the first report to demonstrate the applicability of the TSPY gene for sexing single cells in cattle.

Key words: Sexing; TSPY gene; Bovine; Embryo; Single cell; Cattle

\section{INTRODUCTION}

The identification of bovine embryo gender can be very useful for research involving differential expression of genes between males and females (Chrenek et al., 2001; BermejoAlvarez et al., 2008). Similarly, it can be a valuable tool for assisted reproduction in breeding programs, and may also be commercially explored in the cattle industry.

Many techniques and Y-specific markers have been used for sexing cattle (Lee et al., 2004: Bermejo-Alvarez et al., 2008: Zoheir and Allam, 2010). The application of polymerase chain reaction (PCR) for the analysis of a single cell presents a challenge since limited DNA is available in one single diploid cell, and this can lead to a reduction in amplification efficiency. Lemos et al. (2005) described a study on the TSPY (testis-specific protein Y-encoded) gene as a male-specific marker for cattle sexing in very low DNA concentrations. The TSPY gene is advantageous compared to other markers because it is a Y-specific gene of multiple copies both in human and bovine genomes. After embryo biopsy, the DNA from only one cell is amplified, so, using genes with multiple copies, we could increase the efficiency of the amplification (Bartmann et al., 2004; Lemos et al., 2005).

In the present study, we tested a nested PCR-based protocol, modified from Lemos et al. (2005), in order to sex single cells from bovine preimplantation embryos using a sequence of the TSPY gene (also known as DYS14 in humans).

\section{MATERIAL AND METHODS}

\section{Bovine embryos}

Immature bovine cumulus-oocyte complexes (COCs) were aspirated from 2- to 7-mm follicles in the ovaries of slaughtered cows (Nelore cattle - Bos indicus). The selected oocytes were washed twice in $\mathrm{H} 199+$ medium and twice in B199+ maturation medium. COCs were cultured in $5 \% \mathrm{CO}$, at $38.7^{\circ} \mathrm{C}$ for $22-24 \mathrm{~h}$ for maturation, in $\mathrm{B} 199+$ covered with mineral oil. The semen straws from Nelore bulls (Bos indicus) were thawed, and the semen was separated on a Percoll (GE) gradient. After the maturation period, the COCs were washed twice in the in vitro fertilization (IVF) medium, and co-incubated with the motile spermatozoa in microdrops of $100 \mu \mathrm{L}(90 \mu \mathrm{L}$ IVF medium $+10 \mu \mathrm{L}$ spermatozoa pellet diluted in IVF medium to a concentration of $2.0 \times 10^{6}$ spermatozoa $/ \mathrm{mL}$ ) covered with mineral oil. The oocytes and spermatozoa were co-incubated for $12-15 \mathrm{~h}$ in $5 \%$ of $\mathrm{CO}_{2}$ at $38.7^{\circ} \mathrm{C}$.

After the fertilization period, the zygotes were washed in IVF medium and three times in $\mathrm{CR} 2+$ medium. They were co-cultivated in CR2+ medium for $72 \mathrm{~h}$. After this period, the viable embryos ( 8 -16 cells) were washed and transferred to microdrops with manipulation medium, and, using a micropipette $10 \mu \mathrm{m}$ in diameter coupled to a micromanipulator (Narishigi Co. Ltda., Tokyo, Japan), the embryos were fixed. With the biopsy pipette (35- $\mu \mathrm{m}$ diameter), 
the zona pellucida was broken, and a single blastomere was removed. From each embryo, at least two blastomeres were individually removed. Each single blastomere and the rest of the embryo were individually stored in tubes at $-80^{\circ} \mathrm{C}$.

\section{Molecular analysis}

In the present study, DNA extracted from 18 biopsied embryos (10 obtained by IVF using non-sexed semen, and 8 , by IVF using sexed sorted semen, specific for generating male embryos) were analyzed. We carried out a thermal-shock DNA extraction and $1 \mu \mathrm{L}$ proteinase $\mathrm{K}(25 \mathrm{mg} / \mathrm{mL})$ and $49 \mu \mathrm{L} 0.005 \%$ SDS were added. The tubes were incubated in a water-bath at $55^{\circ} \mathrm{C}$ for $1 \mathrm{~h}$, and incubated in a dry-bath for $30 \mathrm{~min}$ at $99^{\circ} \mathrm{C}$. The tubes were immediately transferred to ice, and the PCR solution was added.

The sequences of the primers, based on sequences reported in other studies (GenBank No. X74028.1, B. taurus TSPY gene) (Jakubiczka et al., 1993), were as follows: forward primer (Ext TSPY S) 5'-CCCGCACCTTCCAAGTTGTG-3', reverse primer (Ext TSPY AS) 5'-TGCTCCTC CACCGTCTTCT-3'. The second set of primers was: 5'-TTGTCACCAGCAGTTGTCACG-3' (Int TSPY S) and 5'-AACCTCCACCTCCTCCACGATG-3' (Int TSPY AS)

The first PCR contained $12.05 \mu \mathrm{L}$ MilliQ water, buffer solution with $1.5 \mathrm{mM} \mathrm{MgCl}$ Crimson Taq reaction buffer $(10 \mathrm{mM}$ Tris- $\mathrm{HCl}, 100 \mathrm{mM} \mathrm{KCl}, 0.1 \mathrm{mM}$ EDTA, $1 \mathrm{mM}$ dithiothreitol, $0.5 \%$ Tween 20, 0.5\% NP-40 and 50\% glycerol) (New England BioLabs Inc.), $0.1 \mathrm{mM}$ of each dNTP (Invitrogen), $10 \mathrm{pmol}$ of each external primer (forward and reverse), $0.625 \mathrm{U}$ Crimson Taq DNA polymerase and $8 \mu \mathrm{L}$ lysis solution containing all the extracted DNA. The second PCR consisted of $22 \mu \mathrm{L}$ MilliQ water, buffer solution with $1.5 \mathrm{mM} \mathrm{MgCl}$, Crimson Taq reaction buffer (New England BioLabs Inc.), $0.1 \mathrm{mM}$ of each dNTP, 10 pmol of each internal primer (forward and reverse), $0.625 \mathrm{U}$ Crimson Taq DNA polymerase and $3 \mu \mathrm{L}$ first PCR product.

The DNA sequence was amplified in a T Gradient (Biometra) thermocycler by an initial denaturation step at $95^{\circ} \mathrm{C}$ for $1 \mathrm{~min}$, followed by 40 cycles of denaturation at $95^{\circ} \mathrm{C}$ for $45 \mathrm{~s}$, annealing at $60^{\circ}$ and $64^{\circ} \mathrm{C}$ (first and second PCR, respectively) for $45 \mathrm{~s}$ and elongation at $68^{\circ} \mathrm{C}$ for $45 \mathrm{~s}$. An additional extension time of $10 \mathrm{~min}$ at $10^{\circ} \mathrm{C}$ was added at the end of the final cycle. The amplification products $(328 \mathrm{bp}$ for the first set of primers, and $153 \mathrm{bp}$ for the second) were analyzed by electrophoresis in $8 \%$ polyacrylamide gels stained with $2 \%$ silver nitrate. As a DNA positive control, we used a bovine $\beta$-actin gene sequence previously described (Rios et al., 2007).

We compared the results of each single blastomere (in a total of two blastomeres from each embryo) with the data obtained from the other blastomere and the remaining cells of the same embryo. Each reaction contained DNA extracted from testis (male control) and cow blood samples (female control) as controls.

\section{RESULTS}

The results are illustrated in Figure 1 and summarized in Table 1. For all embryos, the results of the three samples (two blastomeres and the remaining cells of the embryo) matched. All sexed semen-derived embryos showed results compatible with male embryos, as expected. 


\section{M F 1A 1B 1E 2A 2B 2E 3A 3B 3E 4A 4B 4C B}

$200 \mathrm{bp}-$

$153 \mathrm{bp}-$

$100 \mathrm{bp}-$

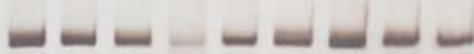

Figure 1. Results of polyacrylamide gel electrophoresis with silver nitrate staining. When the band (153 bp) was present, the result was considered TSPY-positive. (L) molecular marker (100 bp); (M) testicular tissue or male control; (F) cow's blood or female control: (1-4) embryos numbered according to Table 1: (A and B) single blastomeres; (E) remaining cells of the matched embryo; (B) negative control without DNA.

\begin{tabular}{|c|c|c|c|c|}
\hline \multirow[t]{2}{*}{ Embryos } & Blastomere 1 & Blastomere 2 & Remaining cells & Gender \\
\hline & $T$ TSPY & $T$ TSPY & $\begin{array}{l}T S P Y \\
\end{array}$ & \\
\hline \multicolumn{5}{|c|}{ Non-sexed semen } \\
\hline 1 & . & . & . & Female \\
\hline 2 & + & + & + & Male \\
\hline 3 & + & + & + & Male \\
\hline 4 & + & + & + & Male \\
\hline 5 & + & + & + & Male \\
\hline 6 & . & - & . & Female \\
\hline 7 & + & + & + & Male \\
\hline 8 & + & + & + & Male \\
\hline 9 & . & . & . & Female \\
\hline 10 & + & + & + & Male \\
\hline \multicolumn{5}{|c|}{ Sexed semen } \\
\hline 11 & + & + & + & Male \\
\hline 12 & + & + & + & Male \\
\hline 13 & + & + & + & Male \\
\hline 14 & + & + & + & Male \\
\hline 15 & + & + & + & Male \\
\hline 16 & + & + & + & Male \\
\hline 17 & + & + & + & Male \\
\hline 18 & + & + & + & Male \\
\hline
\end{tabular}

\section{DISCUSSION}

The genomic TSPY organization of the bovine and human genes is highly conserved (Vogel et al., 1997). In Bos taurus, most breeds have a similar average TSPY copy number (94 copies) (Hamilton et al., 2009). In a previous study, we reported that PCR using primers derived from a TSPY sequence allows the detection of the $\mathrm{Y}$ chromosome in male animals (Nelore cattle) even at low DNA concentrations. These preliminary results showed the potential of this gene as a male-specific marker (Lemos et al., 2005).

In the present study, we were able to identify embryo sex in a quick and specific way, using a single biopsied blastomere and a nested PCR with the TSPY gene.

Despite the fact that the accuracy of the sexed sorted sperm process is about $90 \%$ (Seidel, 2003), we carried out experiments with embryos produced with this type of sperm in an attempt to produce more male embryos. In fact, we obtained $100 \%$ presumptive male embryos in this small sample set. The sex determination of bovine embryos using TSPY 
Sexing single bovine blastomeres

sequences may be useful in future efficiency studies of sorting sperm.

When we studied embryos conceived with unsorted semen, we chose the morphologically superior embryos, with higher number of cells, which could explain the disproportion of males and females (7:3, respectively). This was observed in the embryos conceived by non-sexed semen, probably due to differences in the in vitro development between males and females bovine embryos.

The results of $100 \%(36 / 36)$ of blastomeres (single cells) matched the data from the remaining cells of the same embryo. The mechanism that explains the accuracy of our results is that the TSPY is multicopied in the male bovine genome and differs from other Y-specific genes such as the $S R Y$ gene utilized in some studies, which has only one copy.

Due to the importance of preimplantation sexing and genetic diagnosis, it is necessary to have highly sensitive and specific techniques. On the other hand, they also need to be inexpensive and less time-consuming. This protocol could be used as a screening test of embryo sex in expression experiments using pools of embryos, and to test accuracy of the sexed sorted sperm process or the quality of sexed sorted sperm lots. Another technical option could be real-time PCR, but the equipment required is much more expensive than the one used for a simple nested PCR. The latter can be found in services with low complexity and financial resources. It is a very important advantage, for example, in developing countries.

The present study is the first report in the literature using the TSPY gene for bovine embryo sexing of a single cell.

\section{ACKNOWLEDGMENTS}

Research supported by FAPESP (Processes \#2005/00616-5 and \#2009/08313-2), CNPq (Process \#408856/2006-8), ANCP, and FAEPA. We thank the staff of the Epigenetics and Reproduction Group, especially Mrs. Marli A.V. Galerani.

\section{REFERENCES}

Bartmann AK, Ramos ES, Caetano LC, Rios AF, et al. (2004). TSPY detection in blood, buccal, and urine cells of patients with 45,X karyotype. Am. J. Med. Genet. A. 130A: 320-321.

Bermejo-Alvarez P. Rizos D, Rath D, Lonergan P, et al. (2008). Epigenetic differences between male and female bovine blastocysts produced in vitro. Physiol. Genomics 32: 264-272.

Chrenek P, Boulanger L, Heyman Y, Uhrin P, et al. (2001), Sexing and multiple genotype analysis from a single cell of bovine embryo. Theriogenology 55: 1071-1081.

Hamilton CK, Favetta LA, Di Meo GP, Floriot S, et al. (2009). Copy number variation of testis-specific protein, Y-encoded (TSPY) in 14 different breeds of cattle (Bos taumis). Sex Dev. 3: 205-213

Jakubiczka S, Schnieders F and Schmidtke J (1993). A bovine homologue of the human TSPY gene. Genomics 17: 732735.

Lee JH, Park JH, Lee SH, Park CS, et al. (2004). Sexing using single blastomere derived from IVF bovine embryos by fluorescence in situ hybridization (FISH). Theriogenology 62: 1452-1458.

Lemos DC, Rios AFL, Lobo RB and Vila RA (2005). Use of the TSPY gene for sexing cattle. Genet. Mol. Biol. 28: 117 . 119

Rios AFL, Lemos DC, Femandes MB and Andrea MV (2007). Expression of the CTCF gene in bovine oocytes and preimplantation embryos. Genet. Mol, Biol, 30: 1202-1205.

Seidel GE Jr (2003). Economics of selecting for sex: the most important genetic trait. Theriogenology 59: 585-598.

Vogel T, Dechend F, Manz E, Jung C, et al. (1997). Organization and expression of bovine TSPY. Mamm. Genome 8:

$$
\text { 491-496. }
$$

Zoheir KM and Allam AA (2010). A rapid method for sexing the bovine embryo, Anim. Reprod. Sci. 119: 92-96. 


\section{Differential expression of genes in follicular cells of swines ${ }^{1}$}

Cristiana Libardi Miranda Furtado ${ }^{2}$, Priscila Vendramini Silva ${ }^{2}$, Marta Fonseca Martins Guimarães $^{3}$, Nicola Vergara Lopes Serão ${ }^{2}$, José Domingos Guimarães ${ }^{4}$, Simone Eliza Facioni Guimarães ${ }^{2}$

'Apoio financeiro: CAPES, CNPq, FAPEMIG e FINEP.

${ }^{2}$ Departamento de Zootecnia - Universidade Federal de Viçosa, Viçosa - Minas Gerais, Brasil.

${ }^{3}$ Empresa Brasileira de Pesquisa Agropecuária - Embrapa Gado de Leite. Juiz de Fora - Minas Gerais, Brasil.

${ }^{4}$ Departamento de Veterinária - Universidade Federal de Viçosa. Viçosa - Minas Gerais, Brasil.

ABSTRACT - The main purpose of the present study was to identify for candidate genes related to ovulation in swines. To do so, it was investigated in ovarian follicular cells through quantitative real-time PCR the differential expression of the following genes; steroidogenic acute regulator (STAR), GATA-binding protein 4 (GATA), prostaglandin F2 $\alpha$ (PGF $2 \alpha$ ), progesterone receptor (P4R), follicle-stimulating hormone receptor (FSHR), and cytochrome P450 aromatase (CYP19). These genes encode hormone receptors (FSHR and P4R), hormone (PGF2 $\alpha$ ), steroidogenic proteins (STAR and CYP19) and transcription factor (GATA). Folicular cells were collected from sows with high and low number of piglets/litters during the follicular phase of the estrus cycle. There was difference in transcript abundance among low and high prolific sows for the STAR, GATA, PGF2 $\alpha$, P4R and CYP19 genes. For the FSHR gene, the fold change was not considered to be significantly different. Because in the present study only the transcript level of the above mentioned genes was analyzed, no inference can be made regarded to protein translation or activity. Therefore, gene sequence trials and other functional studies will be necessary to complement the present results, allowing a better understanding on biological complexity of these genes and their use as markers for prolificity in swines.

Key Words: candidate gene, litter size, ovulation rate, pig production, quantitative real-time PCR

\section{Expressão diferencial de genes em células foliculares de suínos}

RESUMO - O objetivo neste trabalho foi identificar genes candidatos relacionados à ovulaçào em suinos. Para tanto, investigou-se a expressão diferencial dos genes STAR (steroidogenic acute regulator), GATA (GATA-binding protein 4), PGF2 $\alpha$ (prostaglandin F2 $\alpha$ ), P4R (progesterone receptor), FSHR (follicle-stimulating hormone receptor) e CYP19 (cytochrome P450 aromatase) em células foliculares ovarianas por meio de reação em cadeia da polimerase em tempo real ( $\mathrm{qRT}-\mathrm{PCR}$ ) quantitativo em tempo real. Esses genes codificam para receptores hormonais (FSHR e P4R) hormônio (PGF2 $\alpha$ ), proteinas esteroidogênicas (STAR e CYP19) e fator de transcrição (GATA). As células foliculares foram coletadas durante a fase folicular do ciclo estral de poreas com alto e baixo número de leitões/leitegada. Houve diferença na abundância de transcritos entre porcas com alta e baixa prolificidade para os genes STAR, GATA, PGF2 $\alpha$, P4R and CYP19. Para o gene do FSHR, a alteração na abundância dos transcritos não foi significativamente diferente. Considerando que foi analisado somente o nivel de transcrição desses genes mencionados, não se pode fazer inferências com relação à tradução ou atividade proteica. Portanto, ensaios de sequenciamento gênico $\mathrm{e}$ outras análises funcionais serão necessários para complementar esses achados e possibilitar melhor entendimento da complexidade biológica desses genes e seu uso como marcadores para prolificidade em suinos.

Palavras-chave: genes candidatos, ovulação, produção de suinos, PCR quantitativo em tempo real, tamanho de leitegada

\section{Introduction}

Swine is a high prolific animal, with a productivity of more than 20 piglets/sow/year (Johnson et al., 1999). An increase in reproductive efficiency has been observed over the last few decades, mainly as a result of genetic improvement of the herds. Among reproduction traits, reproductive performance, especially the number of piglets per litter, is fundamental for the success of pig production, where the increase in prolificity reduces production costs (Barbosa et al., 2008). However, this trait is sex-limited and shows low heritability of about 0.10 (Chen et al., 2003) and 0.22 (Torres-Filho et al., 2005), which represents a strong candidate for marker-assisted selection. Concerning to litter 
size, two factors are intimately related, ovulation rate and embryo survival or mortality. The ovulation rate refers to the number of oocytes released during the estrus period and it is one of the most important components of prolificity (Caetano et al., 2003). Because of this, the study of gene expression in ovarian follicular cells during different phases of the estrus cycle may have a high impact on the understanding of the reproductive biology of the swine, leading to the improvement of ovulation rates and consequently to an increase in litter size.

Molecular techniques used for the identification of genes or quantitative trait loci (QTL) for litter size are fundamental tools for the genetic understanding and improvement of reproductive traits when combined with traditional methods of selection. Concerning to this line of research, many strategies have been suggested, including the analysis of transcribed sequences for the characterization of gene function (Adams et al., 1991; Hatey et al., 1998). In this respect, the present study investigates candidate genes on the bases of their expression profiles. In order to reach this objective, the transcript abundance for the steroidogenic acute regulator gene (STAR), GATA binding protein 4 (GATA), prostaglandin $F_{2 \alpha}\left(\mathrm{PGF}_{2 \alpha}\right)$, progesterone receptor ( $\mathrm{P} 4 \mathrm{R})$, follicle-stimulating hormone receptor (FSHR) and cytochrome aromatase P450 (CYP19) were evaluated regarded to their differential expression profiles in follicular cells of high- and low-prolific sows using the technique of quantitative real-time PCR (qPCR).

\section{Material and Methods}

Follicular fluid samples were collected from commercial sow (Landrace $x$ Large White $\times$ Pietrain) deriving which belongs to the Pig Breeding Program from the Departamento de Zootecnia of Universidade Federal de Viçosa. For sample collection, three high prolific and three low prolific sows were selected according to the number of piglets born alive during their first three parities, which is in average 12 for the high prolific group and 8.5 for the low prolific ones and because they belonged to a breeding programe, no more females were slaughtered (especially the high prolific ones), when this occurred, it was during the estrus cycle, however.

The statistical difference between the total number of piglets born (TNPB) and number of piglets born alive (NPBA) between both groups was calculated by Student t-test.

Follicular cells were collected immediately after slaughter from low and high prolific sows by puncture and aspiration of ovarian follicles during the estrus cycle
(10-20 $\mathrm{mm}$ ), using a disposable $5-\mathrm{mL}$ syringe with a needle. After aspiration, the follicular cells were pelleted by centrifugation and washed 2-3 times in $1 \mathrm{X}$ phosphatebuffered saline (PBS). The cells were resuspended in the same buffer and the number of cells in each sample was calculated by a Neubauer chamber counting. After counting, the cells were resuspended in RLT buffer (RNeasy Mini Kit, Qiagen, Valencia, CA, USA) supplemented with B-mercaptoethanol for extraction of total RNA

Total RNA was extracted immediately after cell counting using the RNeasy Mini Kit (Qiagen) according to manufacturer recommendations. The samples were treated with DNase (RNase-Free DNase Set, Qiagen) as recommended by the manufacturer. The total RNA obtained was quantified by spectrophotometry and the $\mathrm{OD}_{260} / \mathrm{OD}_{280}$ ratio was calculated to evaluate RNA quality. RNA was stored at $-70^{\circ} \mathrm{C}$ until it was needed for use.

For cDNA synthesis, total RNA from animals of the same class was pooled, one pool from low prolific sows and the other from high prolific sows diluted at the same concentration. The material was pooled because of the search for general differences that could be assigned to high and low prolificity groups; individual results were not being investigated at that time. The first strand was synthesized from the total RNA template using the SuperScript III First-Strand Synthesis SuperMix Kit (Invitrogen, Carlsbad, CA, USA) according to manufacturer instructions. In both pools, cDNA concentration was determined by spectrophotometry before being stored at $-20^{\circ} \mathrm{C}$ until its use in the qPCR reactions.

The sequences were obtained from GenBank database (http://www.ncbi.nlm.nih.gov) (Table 1). The selected genes encode hormone receptors as a FSHR (Follicle-stimulating hormone receptor) and $\mathrm{P} 4 \mathrm{R}$ (Prostaglandin receptor), hormone $\mathrm{PGF}_{2 \alpha}$ (Prostaglandin $\mathrm{F}_{2 \alpha}$ ), steroidogenic proteins STAR (Steroidogenic acute regulator) and CYP19 (Cytochrome P450) and transcription factor GATA (GATAbinding protein 4). According to Huggett et al. (2005), the GAPDH and B-actin genes are the ones most used for studies of gene expression and these genes were tested as endogenous control. The best efficiency of the reaction, showed by the standard curve, was showed by $B$-actin gene which was then used as a reference. The primers for the target genes and for the endogenous control ( $B$-actin) were designed using the PrimerQuest program (http:// www.idtdna.com) provided by Integrated DNA Technologies, Inc. (Coralville, IA, USA) (Table 1).

Quantitative real-time PCR was performed by using ABI PRISM $^{\otimes} 7000$ Sequence Detection System (Applied 
Biosystems, Foster City, CA, USA). Relative quantification was performed using $B$-actin gene as endogenous control and the SYBR ${ }^{\circledR}$ Green Kit as detection system (Bio-Rad, Hercules, CA, USA). To estimate the efficiency of the reactions, different concentrations of primers and $c D N A$ were tested for the target and the $B$-actin genes. Four cDNA concentrations $(200,100,10$ and $1 \mathrm{ng})$ and three primer dilutions $(400,200$ and $100 \mathrm{nM})$ were tested. The best cDNA concentration for amplification was $200 \mathrm{ng}$ for the $\mathrm{PGF}_{2 \alpha}$ gene and $100 \mathrm{ng}$ for the other genes. The optimized primer concentrations were $200 \mathrm{nM}$ for the B-actin, STAR, CYP19 and FSHR genes and $400 \mathrm{nM}$ for the $\mathrm{PGF}_{2 \alpha}$, GATA and P4R genes. The efficiency of the reaction was calculated according to Livak \& Schmittgen (2001) and as published by Guimarães et al. (2007).

The reaction mixture contained $12.5 \mu \mathrm{L} 2 \mathrm{X}$ SYBR $\mathbb{R}$ Green Supermix (buffer, dNTPs, $\mathrm{MgCl}_{2}, \mathrm{SYBR}^{\mathbb{B}}$ Green and Taq DNA polymerase), primers and cDNA at the concentrations described above in a final volume of $25 \mu \mathrm{L}$. The reaction for each gene was carried out in individual tubes, and each sample was tested in replicate, for the target and the control genes. The following amplification conditions were used for all systems: $95^{\circ} \mathrm{C}$ for $3 \mathrm{~min}, 40$ cycles of denaturation at $95^{\circ} \mathrm{C}$ for 15 seconds and annealing and extension at $60^{\circ} \mathrm{C}$ for 60 seconds. After the 40 amplification cycles, all samples were submitted to the analysis of the dissociation curve to validate the absence of nonspecific products or primer dimers.

Transcript abundance for each target gene was evaluated by the formula $2^{-\Delta C}$ (Livak \& Schmittgen, 2001), in which $\Delta \mathrm{C}_{\mathrm{t}}=\mathrm{C}_{\mathrm{t}}$ (target gene) $-\mathrm{C}_{\mathrm{t}}$ (control gene). The transcript abundance for target genes in follicular cells from low and high prolific pool samples were calculated based on the cycle threshold $\left(\mathrm{C}_{\mathrm{t}}\right)$. Differences in the expression of each gene were represented by the value of $2^{-\Delta C}$ (arbitrary units). The fold changes are reported by the number of times that each gene was expressed in the low prolific pool than in the high prolific pool $(\mathrm{L} / \mathrm{H})$. Differences in expression of 1.5 times or higher between low and high prolific pools were considered differentially expressed.

Table 1 - Primer sets used for the amplification of each gene by real-time PCR

\begin{tabular}{|c|c|c|}
\hline Gene & GenBank accession number & Primer \\
\hline FSHR & $\mathrm{Nm} \_214386$ & $\begin{array}{l}\text { F-AGAACTTCCGCAGGGATGTCTTCA } \\
\text { R-TTGGATGAATGTTGTGGGCAGTGG }\end{array}$ \\
\hline P4R & S49016 & $\begin{array}{l}\text { F-AGCTCACAGCGTTTCTACCAGCTT } \\
\text { R-GGAAATTCAACACTCAGTGCCCG }\end{array}$ \\
\hline $\mathrm{PGF}_{2 \alpha}$ & $\mathrm{Ab} 115763$ & $\begin{array}{l}\text { F-TGACTACAAGAACTACGCCCTGCT } \\
\text { R-AGACAATGCCGTCCTCTGTGAAG }\end{array}$ \\
\hline STAR & NM_213755 & $\begin{array}{l}\text { F-TGTTCATCCAGCCAGGAGCTTCA } \\
\text { R-AACCAGAGTGGATGTTGCTGCAC }\end{array}$ \\
\hline CYP19 & S80148 & $\begin{array}{l}\text { F-TGAGGCAACAGGAGTCCTAAATG } \\
\text { R - ATCTTGTGTTGCTTGATCTCAGGG }\end{array}$ \\
\hline GATA & $\mathrm{Nm} \_214293$ & $\begin{array}{l}\text { F-CAAATCGAAGACGTCAGCAGGTC } \\
\text { R-TCTGTCTTGATGGGACGCATCTCT }\end{array}$ \\
\hline$\beta$-Actin & AJ 312193 & $\begin{array}{l}\text { F-TCATGAAGATCCTCACGGAGCG } \\
\text { R-CGTAGCAGAGCTTCTCCTTGATGT }\end{array}$ \\
\hline
\end{tabular}

\section{Results and Discussion}

Mean TNPB and NPBA were 8.53 and 8.51 in the low prolific group, respectively, and 13.23 and 12.03 in the high prolific group, and the difference in these parameters was significant $(\mathrm{P}<0.01)$ between both groups (Table 2 ).

The highest fold change was observed for the P4R gene, followed by the $\mathrm{PGF}_{2 \alpha}$, STAR, CYP19 and GATA genes. The FSHR gene showed a fold change indicating no differential expression according to this study (Table 3 ).

Petretto et al. (2006) stated that quantitative variation in gene expression levels acts as an intermediate phenotype situated between DNA sequence variation and more complex phenotypes. According to these authors, in most studies on expression of quantitative trait loci, the genomic thresholds for significance typically correspond to fold changes in gene expression greater than $1.5-2$, which would limit the sensitivity to detect only cis-acting effects. In the present study, five out of six genes showed fold changes in transcript abundance. This finding might lead to the inclusion of these differentially expressed genes as strong candidates for further analysis concerning ovulation rate and prolificity in the swine.

In the present study, the gene displaying the greatest fold change (7.73) was P4R. The P4R protein mediates the physiological effects of progesterone, the main hormone 
produced by the corpus luteum. Progesterone is responsible for the implantation and maintenance of pregnancy in mammals, playing a key role in a series of coordinated steps comprising the implantation period of the embryo into the uterus (Ying et al., 2001). Peralta et al. (2005) analyzed the expression of progesterone receptors in the oviduct of sows during the follicular and luteal phase of the estrus cycle. The authors showed that the ovarian hormones estrogen and progesterone are respectively the main up and down physiological regulators of $\mathrm{P} 4 \mathrm{R}$ concentration and that post-translational control of the receptor levels seems to be more important than its transcriptional control, because according to those authors, mRNA levels did not differ significantly during the estrus cycle phases. In the present study, expression of the $\mathrm{P} 4 \mathrm{R}$ gene, evaluated during the follicular phase, was higher in low prolific animals than in high prolific animals. In our study, low prolific sows presented high transcript levels for P4R during the follicular phase, so they might present lower concentration of progesterone, when compared to the high prolific ones, once this hormone is a down-regulator of its receptor. This hypothesis still needs to be tested, however.

The second greatest fold change (2.84) was observed for the gene that encodes prostaglandin $\mathrm{F}_{2 \alpha}\left(\mathrm{PGF}_{2 \alpha}\right)$. This hormone is responsible for luteolysis and the consequent onset of the follicular phase (McCracken et al., 1999). The

Table 2 - Mean phenotypic data obtained for the analyzed sows.

\begin{tabular}{|c|c|c|}
\hline Sow & $\begin{array}{l}\text { Total number of } \\
\text { pipipliget piglets born }\end{array}$ & $\begin{array}{c}\text { Number of } \\
\text { piglets born alive }\end{array}$ \\
\hline High prolific sows, & 13.2 & 12.2 \\
\hline High prolific sows & 14.0 & 12.4 \\
\hline High prolific sows 3 & 12.5 & 11.5 \\
\hline $\begin{array}{l}\text { Average standart } \\
\text { deviation }\end{array}$ & $13.23(0,75)$ & $12.03(0.47)$ \\
\hline Low prolific sows & 9.24 & 8.29 \\
\hline Low prolific sows & 8.0 & 8.0 \\
\hline Low prolific sows & 9.25 & 9.25 \\
\hline $\begin{array}{l}\text { Average standart } \\
\text { deviation }\end{array}$ & $8.83(0.72)$ & $8.51(0.65)$ \\
\hline
\end{tabular}

Table 3 - Relative difference on expression of the genes STAR, GATA, PGF $2_{\alpha}$, P4R, FSHR e CYP19

\begin{tabular}{lc}
\hline Genes & $\begin{array}{c}\text { Relative difference } \\
\text { Low prolific sows/high prolific sows }\end{array}$ \\
\hline STAR & 2.32 \\
CYP19 & 2.30 \\
GATA & 2.31 \\
P4R & 7.73 \\
FSHR & 0.67 \\
PGF $_{2 \alpha}$ & 2.84 \\
\hline
\end{tabular}

activity of $\mathrm{PGF}_{2 \alpha}$ is mediated by its binding to a membrane receptor ( $\mathrm{FPr}$ ). At the end of the luteolytic phase, an increased number of FPr in the corpus luteum and a decreased concentration of $\mathrm{PGF}_{2 \alpha}$ are observed (McCracken et al., 1999). $\mathrm{PGF}_{2 \alpha}$ is particularly powerful in the interruption of pregnancy during its initial phase and this fact may influence litter size. Another fact showing that high $\mathrm{PGF}_{2 \alpha}$ concentrations may affect the maintenance of pregnancy in low prolific sows is that in pigs the corpus luteum is important for the maintenance of pregnancy and its removal has been shown to result in its interruption (Pilon et al., 1997). The fact that the transcript concentration for this hormone is higher in low prolificity sows may indicate a direct negative impact on prolificity of these animals. However, as we have conducted an experiment based on measure of transcript abundance, we can not infer on protein concentration and activity.

The STAR gene presented a fold change of 2.32. Its product encodes a protein that positively regulates the synthesis of steroid hormones during luteinization and steroidogenesis. The STAR protein participates in these events by facilitating the transport of cholesterol through the mitochondrial membrane, increasing its conversion into pregnenolone, a precursor of all steroids (Lavoie et al., 2004). In swines, the transcription of the STAR gene and the translation of its mRNA are positively regulated during postovulatory luteinization of follicular cells in the corpus luteum, a period directly related to the increased synthesis of progesterone. The same authors have indicated that the expression of STAR is positively regulated by the gonadotrophins $\mathrm{FSH}$ and $\mathrm{LH}$ and negatively regulated by $\mathrm{PGF}_{2 \alpha}$.

In the present study, STAR gene expression was analyzed in follicular phase and it was higher in low prolific sows, maybe because these animals start follicle luteinization earlier, leading to a reduction in the number of ovulated oocytes during estrus cycle and, consequently, to the number of piglets. The higher expression of the $\mathrm{PGF}_{2 \alpha}$ gene in low prolific sows confirms these results, with a reduction of gene expression, since this gene is required for luteolysis. However, since only the amount of mRNA in follicular cells was analyzed, it can be inferred that the message is being transcribed but we cannot do the same about what is happening on the post-transcriptional or post-translational levels.

The expression of the STAR gene is mediated by various transcription factors, including GATA-4-binding protein which is encoded by GATA gene (Lavoie et al., 2004). This gene (fold change of 2.31) belongs to a group of transcription factors responsible for the expression of 
many genes that control the differentiation processes of different cell types. According to Arceci et al. (1993), the expression of the GATA-4 gene is induced by retinoic acid and it is tissue-specific and being expressed in the heart, intestinal epithelium, primitive endoderm and gonads, where this gene plays a key role in the regulation of gene expression. GATA-4 gene is expressed before the differentiation of gonadal cells (Lavoie et al., 2004) and it is extremely important for this event.

In the present study, a higher expression of both STAR and GATA genes was observed in low prolific animals. A higher expression of these genes in low prolific animals would have been expected because GATA gene promotes the expression of the STAR gene, which is responsible for the follicle luteinization that may be interfering in the piglet number per litter. In contrast, no studies regarding the role of the GATA-4 gene in the regulation of the expression of the other genes analyzed are available in the literature. Further studies investigating its action at the pre- and posttranscriptional level are also necessary.

Another gene that plays a key role in steroidogenesis is CYP19 (fold change of 2.30), which encodes cytochrome $\mathrm{P} 450$ aromatase $\left(\mathrm{P} 450_{\text {aro }}\right)$, an enzyme responsible for the biosynthesis of estrogen (Robel, 1993). In a study on the expression of CYP19 in bovine granulosa cells, Vanselow etal. (2004) showed that its expression is associated to epigenetic mechanisms, especially DNA methylation. Many studies have shown different CYP19 gene polymorphisms in different human ethnic groups (Kvitko et al., 2004). The expression of this gene is positively regulated by estrogen, with higher expression levels being observed during the follicular phase of the estrus cycle. After the elevation of luteinizing hormone ( $\mathrm{LH})$, it was observed a reduction in the level of estrogen and the CYP19 gene expression in preovulatory follicles (Komar et al., 2001).

The results concerned to the expression of the CYP19 gene may suggest the presence of higher estrogen concentrations in low prolific animals, since the product of this gene participates in the conversion of androgens to estrogens. Nevertheless, the lower expression of this gene in the high prolific sows may be due to the advanced stage of the analyzed follicles, preovulatory phase. However, for all genes analyzed in this study it is important to consider the genetic background of each animal, what is specially true for the CYP19 gene, because of the gene polymorphisms already identified in humans (Kvitko et al., 2004), and, because of the epigenetic mechanisms that can be associated to gene expression (Vanselow et al., 2004).

The FSHR gene was not differentially expressed according to fold change 0.67 . The main function of follicle- stimulating hormone (FSH) is to stimulate the growth of small and medium ovarian follicles (Mannaertz et al., 1994). This hormone is a follicular recruitment inducer and an apoptosis inhibitor of granulosa cells in swines, representing the main up- regulator of follicular grow and ovulation rate in these animals (Cárdenas \& Pope, 2002).

The amount of FSHR mRNA is relatively high during the initial phase of follicular development, but its concentration rapidly decreases when the follicles grow and reach ovulation, consequently this gene has a small influence on preovulatory follicles, a phase during which luteinizing hormone $(\mathrm{LH})$ plays a central role (Cárdenas \& Pope, 2002). It can be suggested that in the present study transcript levels of follicle-stimulating hormone were almost the same for both pools because of the advanced developmental stage of the analyzed follicles (follicular phase), with no significant difference in expression being observed. Analysis of expression of the follicle-stimulating hormonein other estrus phases, along with other ovulatory hormones, such as FSH and luteinizing hormone, may better evaluate the activity of this gene in low and high prolific sows.

In the present study, only the transcript abundance was evaluated for the candidate genes, and it would also be necessary to determine which type of control of gene expression predominates in all these different genetic systems and whether there are differences in genetic background, such as genomic variants and even epigenetic effects, as described for the CYP19 gene have to be considered. Moreover, it can not be forgotten that ovulation and prolificity are poligenic traits, in which many genes are involved in the phenotype. In this regard, the transcript abundance for regulatory hormones, such as GnRH and others have to be evaluated, as well as their interaction with other genes.

Litter size is not only a function of the ovulation rate; it is well established that an improved embryonic survival and a higher uterine capacity contribute to the phenotype (Foxcroft et al., 2006). Many studies have been done to better estimate the value of ovulation rate in litter size in swines and, according to Rosendo et al. (2007), ovulation rates and embryonic survival in the pre-implantation period increased the number of embryos that survived after the post-implantation period (day 25 to 30 ) and it will exceed the uterine capacity, resulting in uterine crowding and increased prenatal loss. This result typically shows that despite of the ovulation rate, many other factors are to be considered when the trait litter size is to be analyzed. In addition, litter size is not only a multi trait characteristic (ovulation rate, embryo survival, uterine capacity), it also 
shows low heritability, due to its large phenotypic variation mainly attributed to environmental factors such as nutrition and management conditions.

\section{Conclusions}

The expression of the STAR, GATA, PGF ${ }_{2 \alpha}$, P4R, CYP19 genes in follicular cells from sows also identifies expression differences in animals with different reproductive phenotypes. The higher relative gene expression of the STAR, GATA, PGF $2 \alpha$, P4R, CYP19 genes is observed in low prolific sows, and the FSHR gene does not reach the threshold difference established in this study. For the results presented in this study, we can state that the use of the qRT-PCR generates evidences for the selection of candidate genes related to ovulation in swines. In the near future, these genes will have their expression evaluated in different phases of the estrus cycle and will also be evaluated by SNP searching techniques in the aim of finding genomic markers that can be related to reproductive phenotypes. In addition, differences in the expression of these genes and of other related ones during the other phases of the reproductive cycle of sows should be analyzed in order to better understand reproductive phenotypes in pigs.

\section{References}

ADAMS, M.D.; KELLEY, J.M.: GOCAYNE, J.D. et al. Complementary DNA sequencing: expressed sequence tags and human genome project. Science, v.252, p.1651-1656, 1991.

ARCECI, R J: KING, A.A.J. SIMON, M.C. et al. A retinoic acidinducible mouse GATA-4: GATA-binding in factor transcription expressed endodermally derived tissue and heart. Molecular and Cellular Biology, v.13, n. 4, p. 2235-2246, 1993

BARBOSA, L.; LOPES P.S.; REGAZZI A.J. et al. Estimação de parâmetros genéticos em tamanho de leitegada de suinos utilizando análises de caracteristicas múltiplas. Revista Brasileira de Zootecnia, v. 37, n.11, p.1947-1952, 2008 .

CAETANO, A.R.; JOHNSON, R.K.; POMP, D. Generation and sequence characterization of a normalized cDNA library from swine ovarian follicles. Mammalian Genome, v.14, p.65-70, 2003.

CÁRDENAS, H.; POPE, W.F. Control of ovulation rate in swine. Journal of Animal Science, v. 80, p. 36-46, 2002.

CHEN, P. BAAS, T J. MABRY, JW et al. Genetic parameters and trends for litter traits in U.S. Yorkshire, Duroc, Hampshire, and Landrace pigs. Journal of Animal Science, v.81, p.46-53, 2003.

FOXCROFT, G.R.; DIXON, W.T.; NOVAK, S. et al. The biological basis for prenatal programming of postnatal performance in pigs. Journal of Animal Science, 84 (E-suppl), E105-E112, 2006.

GUIMARÃES, S.E.F; STAHL, C.H.: LONERGAN, S.M. et al, Myostatin promoter analysis and expression pattern in pigs. Livestock Seience, v.112, p.143-150, 2007.
HATEY, F.; TOSSER-KLOPP, G.; CLOUSCARD-MARTINATO, C. Expressed sequence tags for genes: a review. Genetic Selection Evolution, v. 30, p. $521-554,1998$.

JOHNSON, R.K.; NIELSEN, M.K.; CASEY, D.S. Responses in ovulation rate embryonal survival and litter traits in swine to 14 generations of selection to increase litter size. Journal of Animal Science, v.77, p.541-557, 1999.

KOMAR, C.M. BERNDTSON, A.K. EVANS, A.C.O. et al. Decline in circulating estradiol during the periovulatory period is correlated with decreases in estradiol and androgen, and in messenger RNA for p450 aromatase and p450 17alphahydroxylase, in bovine preovulatory follicles. Biology of Reproduction, v.64, p.1797-1805, 2001.

KVITKO K.: NUNES, J.C.D.E.B.; HUTZ, M.H. (TTTA)n polymorphism of CYP19 (aromatase gene) in Euro- and AfroBrazilians. Genetics and Molecular Biology, v.27, n.3, p. $335-336,2004$

LAVOIE, H.A.; SINGH, D.; HUI, Y.Y. Concerted regulation of the porcine steroidogenicacute regulatory protein gene promoter activity by follicle-stimulating hormone and insulin-like growth factor I in granulosa cells involves GATA-4 and CCAAT/enhaneer binding protein. Endocrinology, v, 145 n. 7, p. $3122-3134,2004$

LIVAK, K.J.: SCHMITTGEN, T.D. Analysis of relative gene expression data using real-time quantitative $P C R$ and the 22DDCT method. Methods, v.25, p.402-408, 2001.

MANNAERTZ, B.; UILENBROCK, J.; SCHOT, P. et al. Folliculogenesis in hypophysectomized rats after treatment with recombinant human follicle stimulating hormone. Biology of Reproduction, v.51, n.1, p.72-81, 1994.

MCCRACKEN, J.A.; CUSTER E.E.; LAMSA J.C. Luteolysis: a neuroendocrine-mediated event. Physiological Reviews, v.79, n.2, p.263-324, 1999

PERALTA, L.E: OLARTE, M.: ARGAÑARAZ, M. et al Progesterone receptors: their localization, binding activity and expression in the pig oviduct during follicular and luteal phases. Domestic Animal Endocrinology, v.28, p.74-84, 2005.

PETRETTO, E.; MANGION, J.; DICKENS, N.J. et al. Heritability and tissue specificity of expression quantitative trait loci. PLoS Genetics, 2 (10 - e 172); p. 1625-1633, 2006.

PILON, N.; DANEAU, 1.; BRISSON, C. et al. Porcine and bovine steroidogenic acute regulatory protein (StAR) gene expression during gestation. Endocrinology, v.38, n.3, p.1085-1091 1997.

ROBEL P. Steroidogenesis: The enzymes and regulation of their genomic expression. In: THIBAULT C.: LEVASSEUR M.C. HUNTER R.H.F. (Eds.) Reproduction in mammals and man. HUNTER R.H.F. (Eds.) Reproductio
Paris: Elipses, 1993. p.135-142.

ROSENDO A.; DRUET T.; GOGUÉ J. et al. Direct responses to six generations of selection for ovulation rate of prenatal survival in Large White pigs. Journal of Animal Science, v.85, p.356$364,2007$.

TORRES-FILHO R.A.: TORRES R.A.: LOPES P.S et al. Estimativas de parảmetros genéticos para caracteristicas reprodutivas de suinos. Arquivo Brasileiro de Medicina Veterinária e Zootecnia, v. 57, n. 5, p.684-689, 2005.

VANSELOW, J.; FÜRBASS, R.; REHBOCK, F. Cattle and sheep use different promoters to direct the expression of the aromatase cytochrome P450 encodinggene, Cyp19, during pregnancy. Domestic Animal Endocrinology, v.27, p.99-114. pregn
2004

YING, C.: YANG, Y-C.; HONG, W-F. et al. Progesterone receptor gene expression in preimplantation pig embryos. Journal of Endocrinology, v.143, p.697-703, 2001. 